

\title{
Multi-stage growth of the trachytic lava dome of the Puy de Dôme (Chaîne des Puys, France). Field, geomorphological and petro-geochemical evidence
} Catherine Deniel, Pierre Boivin, Didier Miallier, Marie-Christine Gerbe

\section{To cite this version:}

Catherine Deniel, Pierre Boivin, Didier Miallier, Marie-Christine Gerbe. Multi-stage growth of the trachytic lava dome of the Puy de Dôme (Chaîne des Puys, France). Field, geomorphological and petro-geochemical evidence. Journal of Volcanology and Geothermal Research, 2020, 396, pp.106749. 10.1016/j.jvolgeores.2019.106749 . hal-02435148

\author{
HAL Id: hal-02435148 \\ https://hal.uca.fr/hal-02435148
}

Submitted on 20 Nov 2020

HAL is a multi-disciplinary open access archive for the deposit and dissemination of scientific research documents, whether they are published or not. The documents may come from teaching and research institutions in France or abroad, or from public or private research centers.
L'archive ouverte pluridisciplinaire HAL, est destinée au dépôt et à la diffusion de documents scientifiques de niveau recherche, publiés ou non, émanant des établissements d'enseignement et de recherche français ou étrangers, des laboratoires publics ou privés.

\section{(이)(\$)}

Distributed under a Creative Commons Attribution - NonCommercial - NoDerivatives $\mid 4.0$ 
Multi-stage growth of the trachytic lava dome of the Puy de Dôme (Chaîne des Puys, France). Field, geomorphological and petro-geochemical evidence.

\section{Deniel ${ }^{1 *}$, P. Boivin ${ }^{1}$, D. Miallier ${ }^{2}$, M.C. Gerbe ${ }^{3}$}

${ }^{1}$ Université Clermont Auvergne, CNRS, IRD, OPGC, LMV, F-63000 Clermont-Ferrand, France

${ }^{2}$ Université Clermont Auvergne, CNRS-IN2P3, LPC, F-63000 Clermont-Ferrand, France

${ }^{3}$ Université de Lyon, UJM-Saint-Etienne, CNRS, LMV, F-42023 St Etienne, France

* Corresponding author. E-mail address: deniel@opgc.univ-bpclermont.fr

UMR 6524 Laboratoire Magmas et Volcans, Campus Universitaire des Cézeaux, 6 Avenue Blaise Pascal, TSA 60026 - CS 60026, 63178 Aubière cedex, France

Abstract

Understanding lava dome eruptions is a major concern in volcanology regarding the assessment of associated hazards. This question is usually addressed through the study of active calc-alkaline domes, however, alkaline domes remaining poorly known. The Puy de Dôme is the most prominent volcano of the Chaîne des Puys Quaternary intraplate volcanic field in the French Massif Central. It is a complex trachytic lava dome ca. 11 ka old. Field investigations, geomorphological and petro-geochemical studies were performed to understand the magmatic system of this dome and reconstruct its volcanic evolution. The different lava facies were fully characterised and their relationships with the volcano building stages have been established. A new four-step evolution is proposed for the growth of this edifice. Mineralogical and geochemical variations document magmatic differentiation with self-mixing and minor crustal contamination in a zoned reservoir within the upper crust. Magma mixing and crustal contamination through fluids interactions during magma ascent and the involvement of fumarolic activity throughout the edifice building are also documented. Further, this work highlights the specific features of the Puy de Dôme compared to calc-alkaline domes: lack of lava flows and almost complete magma degassing during ascent, resulting in the lack of significant explosive activity until the last eruption step. 


\section{Keywords}

Trachytic lava dome; petro-geochemical evidence; zoned magma reservoir; multi-stage growth; Puy de Dôme volcano; French Massif Central.

\section{Introduction}

Understanding lava dome eruptions, commonly associated to hazardous phenomena, is a major concern in volcanology. Thus, numerous studies were performed to characterise (1) the associated magmas through their viscosity, vesicularity, crystal and volatile contents and (2) address the role of these parameters regarding the dynamics of magma ascent in conduits, extrusion style of magma and effusion rates, and eruptive dynamics which are key factors controlling the formation and evolution of lava domes and their eruptive behavior (e.g., Sparks, 1997; Fink and Griffiths, 1998; Sparks et al., 2000; Watts et al., 2002; Neuberg et al., 2006; Hale and Mühlhaus, 2007; Hale and Wadge, 2008; Burgisser et al., 2010, 2011; Husain et al., 2014; 2018 and references therein). These studies, including analog experiments and numerical modelling, have outlined the high complexity of these magmatic systems and associated eruptions. Magma's initial characteristics and degassing-induced crystallisation during magma ascent have especially been identified as key processes regarding the evolution and eruptive behavior of these domes. The mechanisms associated with lava dome eruptions are usually addressed through the study of calc-alkaline domes as these are numerous, longlived, active and often under monitoring, but not through the studies of extinct monogenetic alkaline domes. Nevertheless, thanks to their simpler magmatic history, associated with a small magma chamber which operated only once (e.g., Eichelberger et al., 1984), alkaline domes are potentially able to bring valuable constraints to the understanding of dome-building eruptions.

The Puy de Dôme (PdD, hereafter), a trachytic lava dome, is the highest (1,465 $\mathrm{m}$ a.s.1.) volcano (Figure 1) of the Chaîne des Puys ( $\mathrm{CdP}$, hereafter), the most recent intraplate Quaternary volcanic field of the French Massif Central (e.g., Boivin and Thouret, 2014; Boivin et al., 2017 and references therein). As an isolated edifice almost in the centre of the $\mathrm{CdP}, \mathrm{PdD}$ is catching attention $100 \mathrm{~km}$ around and has attracted scientists' attention for a long time. In his pioneering work, Guettard (1752) first mentioned the existence of extinct volcanoes in Auvergne. He immediately identified $\mathrm{PdD}$ as a volcano through the nature of its 
rocks but its shape (Figure 1) was still enigmatic. Indeed, it was not fitting with the standard model of volcanoes used at that time: a scoriaceous cone with a crater, possibly associated with a lava flow. Over more than one century, a vigorous controversy persisted among various authors (Guettard versus Garmage [Mergoil and Mergoil, 2014]; Montlosier, 1788; von Buch, 1802; Ramond, 1815; Poulett Scrope, 1827; Lecoq, 1867; Michel-Lévy, 1890), each one defending more or less fanciful propositions to simultaneoulsy account for the shape of the volcano, the nature of its lavas and the presence of similar deposits over tens of $\mathrm{km}^{2}$ around. The authors who first suggested models presaging present-day concepts were Poulett Scrope (1827) and Michel-Lévy (1890). Poulett Scrope first developed a model of protrusion for Sarcoui (Figure 2a), another trachytic dome of the CdP, based on its regular shape, and then extended it to PdD because of their similarity. Michel-Lévy (1890) evoked superficial laccoliths or surface intrusive rocks while observing that the viscous lava forms the core of the edifice sheathed by projections, themselves pushed away and lifted up by the lava. A strong conceptual change was brought by Lacroix witnessing the 1902 eruption of the Montagne Pelée in Martinique and making the link with the PdD (Lacroix, 1904). He identified the Pelean part of PdD dome and a blanket of Vulcanian projections, with the implications of such a dome terminology in terms of eruptive dynamics (Lacroix, 1908). The vent of these Vulcanian deposits was localised at the foot of the PdD (Glangeaud, 1913), and these deposits were later attributed to Cratère Kilian (Camus, 1975), another trachytic volcano (Figure 2). Further, on the basis of detailed field work, Glangeaud applied Lacroix's model to the other trachytic volcanoes of the CdP. Finally, to account for the PdD asymmetry, Camus (1975) complicated the Pelean model by suggesting a resumption of growth after a sectorial collapse of the initial dome.

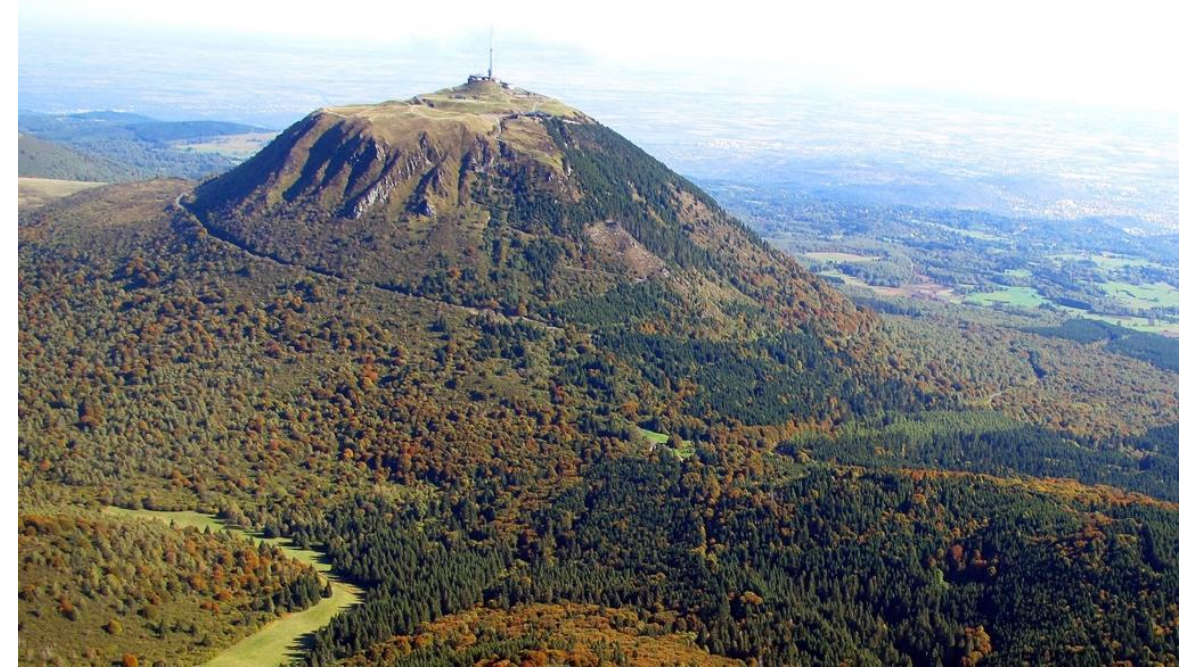


Figure 1 Puy de Dôme volcano, looking NE with a maximum elevation of 1,465 meters above sea level (a.s.1.), hereafter all elevations are given in meters a.s.l.

(C) P. Boivin, 2010)

The layout works at PdD as from 2000-2012 and the local authority's wish to register this place as a "Grand site" and then the "Chaîne des Puys - Faille de Limagne" as a UNESCO World Heritage Site gave new opportunities for observations of the PdD deposits. At the same time, PdD volcano was the focus of geophysical studies: gravimetry, magnetism, 3D electrical imaging (Portal et al., 2016; 2019). It was also chosen as a volcano laboratory for the development of the muonic imagery method (Carloganu, 2018). Our investigations, strongly motivated by the growing interest in dome-building eruptions since Soufrière Hills eruption at Montserrat in 1997 (see references above), took place in this context of renewed interest for this trachytic dome.

Our extensive field work combined with resampling and detailed petrological, mineralogical and geochemical studies was aimed at precisely characterising, for the first time, the lava facies related to the various phases of edification of this lava dome. The eruptive chronology of the volcano and the extent and characterisation of the products (both massive rocks and pyroclastic deposits) associated to each phase have been totally reevaluated. Combined with a high-resolution digital elevation model (DEM, hereafter) plus recent geophysical models, these results allow us to propose a largely renewed scenario for the eruption of this volcano. These results also put new constraints on both magma chamber and conduit processes associated to this monogenetic volcano, as well as its eruptive dynamics that can be compared to those available on complex stratovolcanoes from subduction settings.

\section{The Chaîne des Puys volcanic field}

The volcanism of the French Massif Central has been interpreted as the result of lithospheric thinning due to the Alpine subduction (Eocene-Oligocene) followed by thermal erosion (Upper Miocene-Present) by hot asthenospheric material pushed aside owing to the Alpine continent-continent collision (Zeyen et al., 1997; Merle and Michon, 2001; Babuska et al., 2002). The CdP approximatively built up between $90 \mathrm{ka}$ and $8.6 \mathrm{ka}$ (Boivin et al., 2017). It is composed of about eighty volcanoes lining up on the Plateau des Dômes, an uplifted Variscan basement block separated from the Limagne graben (mainly of Oligocene age) by a steep 
north-south trending escarpment, the Limagne fault (Figure 2). The monogenetic volcanic centres (e.g., Nemeth and Kereszturi, 2015; for a discussion of this concept) display a variety of types which include scoria cones accompanied by lava flows, maars, lava domes, and upheaved plugs. Lavas range from basalts to rhyolites in composition (IUGS classification) and define a series of magmatic differentiation (Bentor, 1954; Batard, 1974). The process of differentiation has been explained by the fractional crystallisation of an alkaline, weakly potassic basalt (Camus, 1975; Maury et al., 1980a; Villemant et al., 1980; Foury, 1983; Boivin et al., 2017). Foury (1983) and Gourgaud and Camus (1984) suggested that differentiation ultimately occurred within intermediate crustal level reservoirs. On the basis of petrological data obtained on CdP trachytes and experimental products from phase equilibria, Martel et al. (2013) refined this model for the trachytic plumbing system of the CdP. They suggested that these intermediate crustal level reservoirs are located between 8 and $16 \mathrm{~km}$ depth, and installed in discontinuities of the network of Variscan faults reactivated during the Neogene. 


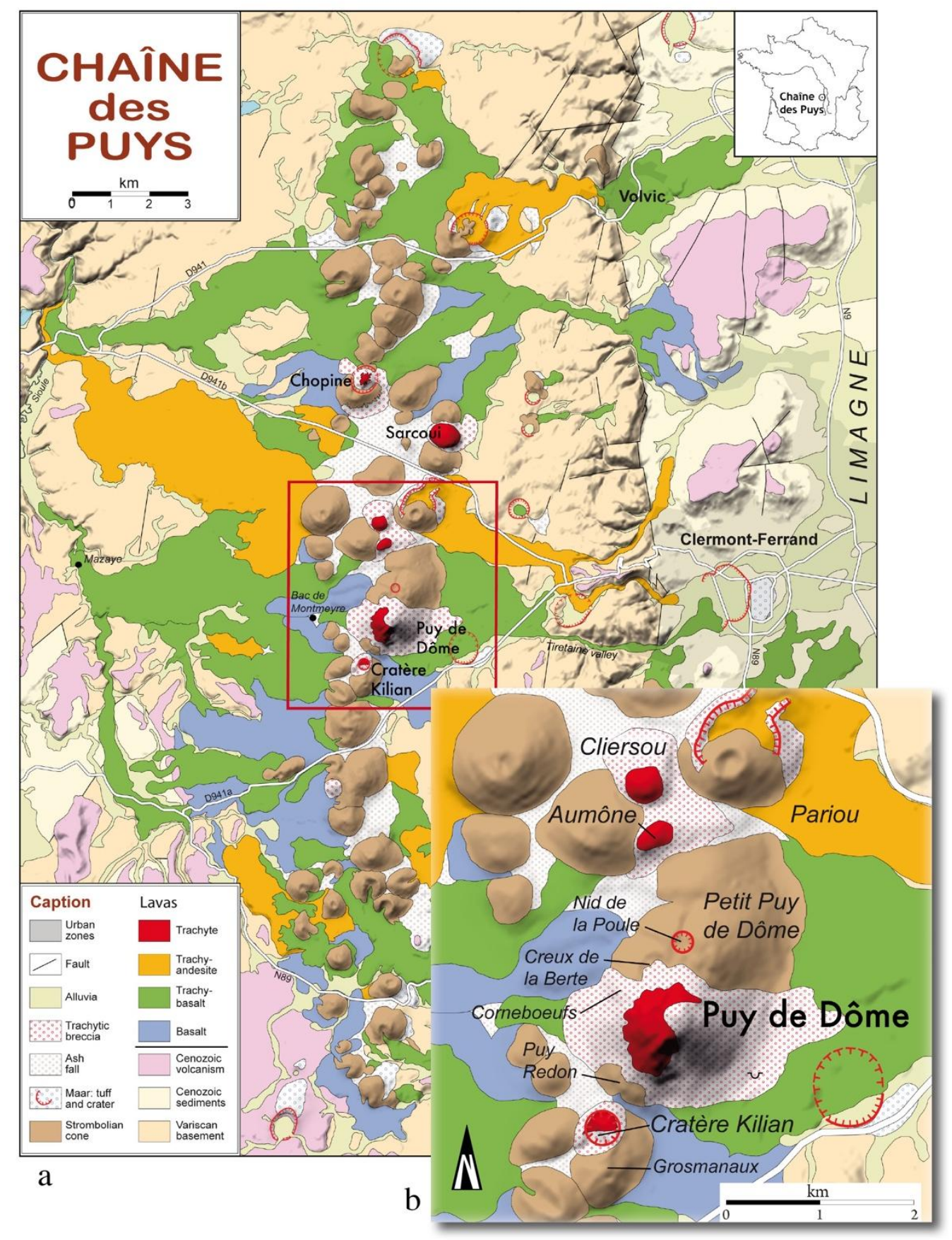

Figure 2 Map of the Chaîne des Puys

(a) Simplified volcanological map modified after Boivin et al. (2017). Red box refers to insert enlarged map (b).

3. PdD volcano and its geological setting

In plan view, PdD has an elliptic shape with a long EW axis and a short NS axis (Figure 2b), measuring about 3,260 and 1,670 m, respectively. The areal extent of PdD was largely 
defined after field work but also strongly benefited from the bottom railway station and car parks buildings which required scrapping of large land areas.

The local basement displays a pronounced asymmetry with a gentle (2.5\%) pre-volcanic slope toward the west and a steeper (about 4.5\%) slope toward the east. Besides, the eastern edge of the plateau is deeply incised by valleys connecting it to the local base level defined by the Limagne graben, at $300 \mathrm{~m}$. Thereby, the basement in the upper part of the Tiretaine valley (Figure 2a), which is opening on the eastern side of $\mathrm{PdD}$, has been identified by drillings and boreholes (Boivin et al., 2017) at 50-70 m depth just at the foot of the eastern flank of the volcano. This basement consists of various units: the Aubusson anatexites, two micas microgranite dykes including the Manson leucogranite, the Royat granite, Visean hornfelses and the Enval syeno-diorite (Jeambrun et al., 1973 and references therein), the two last units being also encountered as xenoliths in the Kilian (Figure 2) deposits. On the western side, valleys are less incised but their lava filling is thicker (90 $\mathrm{m}$ at the Bac de Montmeyre drilling site, Figure 2a). Interpolating data available (outcrops, drillings, and boreholes) on basement elevation around PdD allowed us to put it at about $870 \mathrm{~m}$ a.s.l. at the vertical of PdD summit. Data also suggest that PdD stands on a former ridge between the two valleys containing the Tiretaine lava flow to the east and the Mazayes (Figure 2a) lava flow to the west. This ridge would slope gently from 920 m under Puy de Grosmanaux to 860 m under Petit Puy de Dôme (Figure $2 b$ ) but the lack of close data on the northern side of PdD results in some uncertainty on these values. The openings toward these two opposite valleys account for the EW elongation of the PdD. On the other hand, the pre-existing Strombolian cones of Puy Redon, Cornebœufs, Creux de la Berte and Petit Puy de Dôme (Figure 2b) have limited PdD extension toward the north and south.

PdD does not stand directly on the Variscan basement as indicated by the presence of older volcanic units (cones and lava flows) at its periphery and basaltic xenoclasts brought to the surface during a late minor summit eruption (Miallier et al., 2010). Parts of buried cones were also inferred from geophysical data and the thickness of the underlying lava flows was estimated at about $100 \mathrm{~m}$ (Portal et al., 2016; 2019), outlining that the present apparent volume of the dome is misleading. Consequently, the elevation of $\mathrm{PdD}$ edifice above its local substratum may be estimated at 500 to $550 \mathrm{~m}$, with a total volume of the order of $0.2 \mathrm{~km}^{3}$.

\section{Geomorphological units}


The DEM and tools of quantitative geomorphology (Figures S1 and S2 in Supplementary Information A) allow to determine the main geomorphological units of PdD and their mutual relationships (see details in Supplementary Information A). Four distinct types of geomorphological units were identified: (1) a "dome" shaped constructional landform, (2) the "Eastern Unit" constructional landform, (3) four "aprons" corresponding to typical destructional landforms, and (4) two "pathways" (N.E. and S.) incising the edifice from the summit plateau, and most probably settled in two destructional landforms (Figure 3).

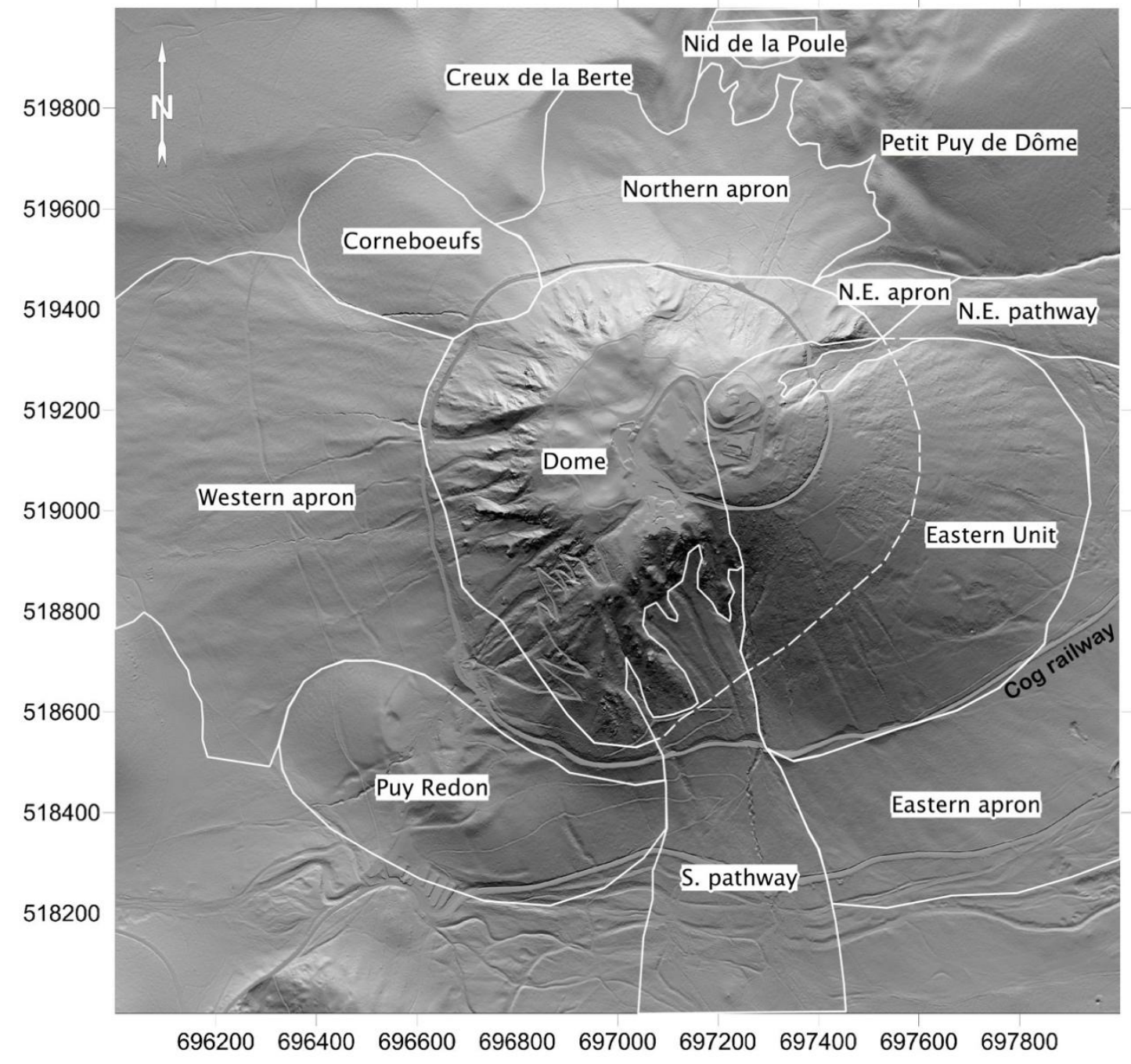

Figure 3 Geomorphological units of the PdD labeled on the high resolution $(0.5 \mathrm{~m})$ DEM (LidArverne/CRAIG - GeoPhenix - 2011) of the center of the CdP.

Four types of geomorphological units are shown: dome, Eastern Unit, aprons (four), and pathways (two). Note also, in close proximity to the dome shape, the three rounded reliefs (Puy Redon, Petit Puy de Dôme and cone of Cornebœufs), partly buried under the edifice (see Supplementary Information A for more details). 


\section{Volcanic units}

Combining field observations and geophysical data, the geomorphological units described above can be ascribed to specific volcanic units.

The morphological "dome" consists of the western part of the volcanic dome which is made of massive porphyritic lavas forming cliffs, spines and spurs.

The morphological "Eastern Unit" corresponds to the Eastern Unit (EU, hereafter) deposits, composed of uniform, consolidated but friable ash, locally embedding blocks of porphyritic lava. This eastern formation is probably not significantly thicker than about 5-15 $\mathrm{m}$, as suggested by outcrops exposed in a long southern radial gully, on the eastern side of the south pathway (Figure 3). Morphologically, it looks younger than the neighbouring formations. On the basis of the DEM and considering a similar extent of the dome on both the eastern and western sides of the volcano, the total volume of this EU deposits is estimated at about 0.007 $\mathrm{km}^{3}$, that is, $3.5 \mathrm{vol} \%$ of the whole edifice.

The stratigraphy of the summit of the dome is now qualitatively well known. Its original surface is rough and chaotic and composed of massive trachytic lava blocks of various size wrapped by white, grey, red or yellowish ashes and lapilli. This surface is locally coated by a very thin $(5-10 \mathrm{~mm})$ soil, itself covered by a few tens of centimeters thick layer of trachytic ashes and lapilli mixed with xenoliths. This layer (the CR formation) was deposited by a late summit eruption, about three centuries after the dome building (Miallier et al., 2010). A soil has developed in its upper part and is covered by the Kilian pyroclastic unit (Colombier et al., 2017). This unit dated at ca. 9.4 ka (Miallier et al., 2012) is mostly composed of amphibolebiotite trachyte and corresponds to the Vulcanian deposits of Lacroix (1908). It is typically about $1 \mathrm{~m}$ thick and coated by the present-day top soil.

A broadly similar sequence is observed on the flanks of the dome wherever it has been preserved from erosion and makes the superficial layers of the "aprons" geomorphological unit. The loose deposits forming the main part of this last morphological unit are observable in ancient quarries (Figure $2 \mathrm{~b}$ ) and in recent excavations. They can be thick (>10 m) and are mainly composed of trachytic boulders of various size (up to a few $\mathrm{m}^{3}$ ) embedded in ash and lapilli (Figure 4). These deposits do not display any stratification or grain size sorting that would be indicative of pyroclastic flow, pyroclastic fall, scree or colluvial deposits and they do not extend further than the bottom of the edifice. Besides, no pyroclastic flow in the surroundings of the PdD can be attributed to it. These deposits are thus considered as block 
and ash flow (BAF) deposits, generated by occasional and small-scale gravitational collapses during the growth of the edifice. Evidence of explosive activity was observed only once as a bomb sag in a thin stratified pyroclastic deposit.

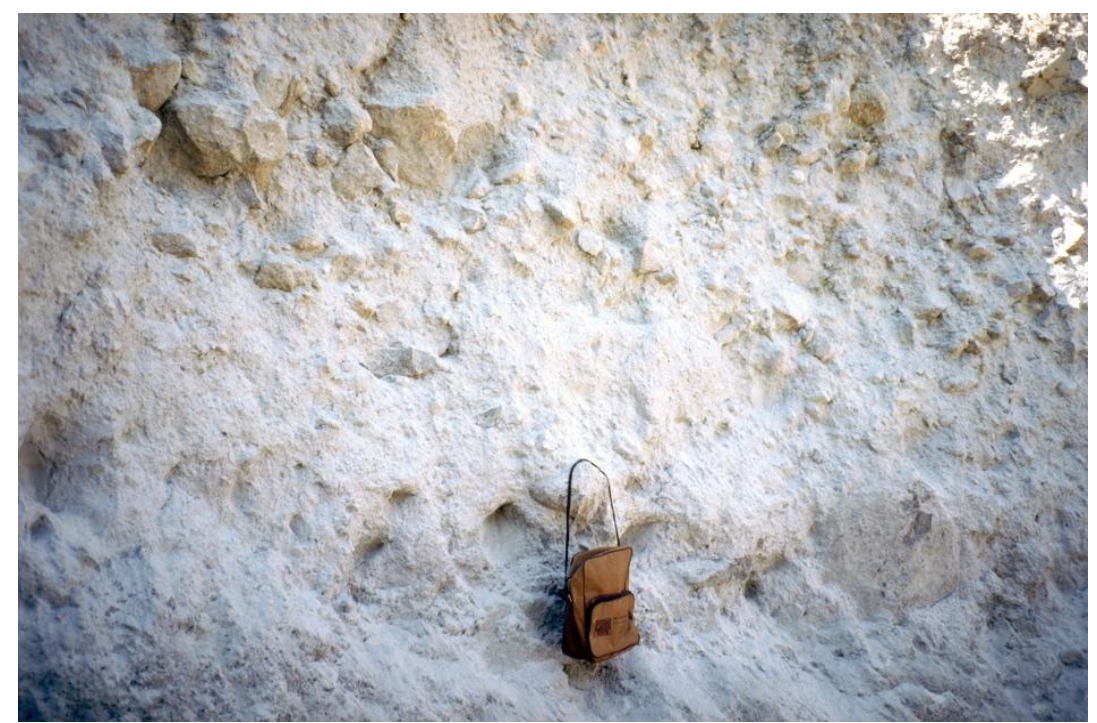

Figure 4 PdD BAF deposits

Outcrop in the ancient quarry located SE of the PdD (Figure 2b). (๔ A. Gourgaud)

A specific trachytic deposit of PdD type is also observed on various outcrops on the Petit Puy de Dôme (Figures $2 \mathrm{~b}$ and 5). It forms a sequence of light coloured layers interbedded in the trachybasaltic tuffs of the Nid de la Poule maar (Lafleur, 2006; Fouillant-Bergeat, 2006), itself related to a slightly younger episode than PdD (ca. $10 \mathrm{ka}$, Miallier et al., 2012). 90\% of these light coloured particles consist of volcanoclasts having a grain size smaller than 250 $\mu \mathrm{m}$. The sequence has a thickness of $10 \mathrm{~cm}$. This deposit, finely stratified and sometimes beveled, consists of a white to yellowish mix of trachytic lava or minerals and mafic lava in various proportions (Figure 5). 


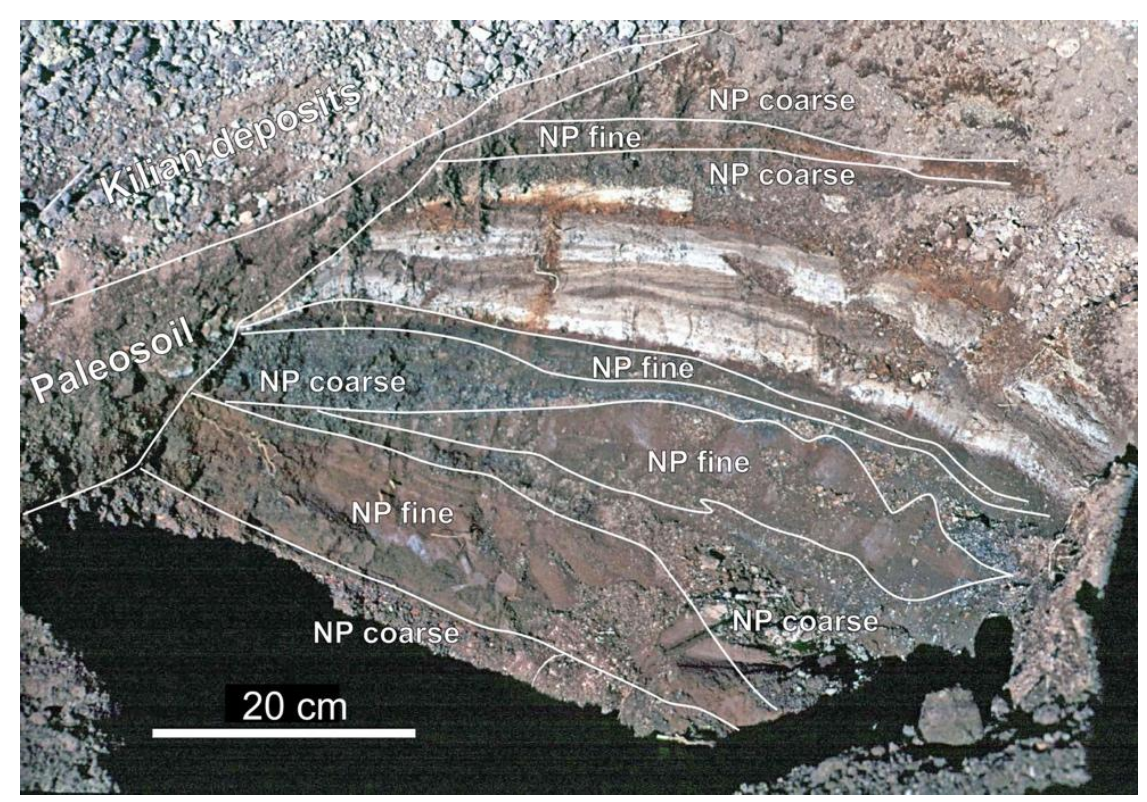

Figure 5 Photograph of the Nid de la Poule outcrop on Petit Puy de Dôme volcano

White trachytic fine grain deposits interbedded in the brown trachybasaltic tuffs of the Nid de la Poule (NP) maar (Figure 2b). The main layers are outlined. ( D. Miallier, 2006)

\section{Inner structure of the volcano}

Some features of the inner structure of the dome can be inferred from field observations. The dome is certainly intensely intruded as documented on its outside surface outcrops by trachytic dykes exhibiting evidence of mechanical deformation and separated by septa of breccia and ash. Besides, an important network of fractures has given way to fumaroles up to the surface. The upper part of the dome displays, often along fissures, many yellow or red stains (Figure 6) or fully bleached rocks, resulting from fumarolic alteration. Large hematite crystals are also present in open fissures. The existence of fractures also probably favoured the late summit eruption (Miallier et al., 2010). Fractures also facilitate the penetration of rain, thereby favouring the alteration of the trachyte. Alteration of the dome at depth is documented by the abundance of fumarolised lapilli in the late summit eruption deposits (CR formation).

Comprehensive geophysical surveys of the whole volcano and its surroundings were performed by means of four distinct methods, namely electrical resistivity tomography (ERT), gravimetry, magnetometry (Portal et al., 2016; 2019) and muography (Ambrosino et al., 2015). The results indicate that the dome, built on pre-existing scoriaceous cones, is highly heterogeneous at various scales and suggest that its core is significantly altered. 


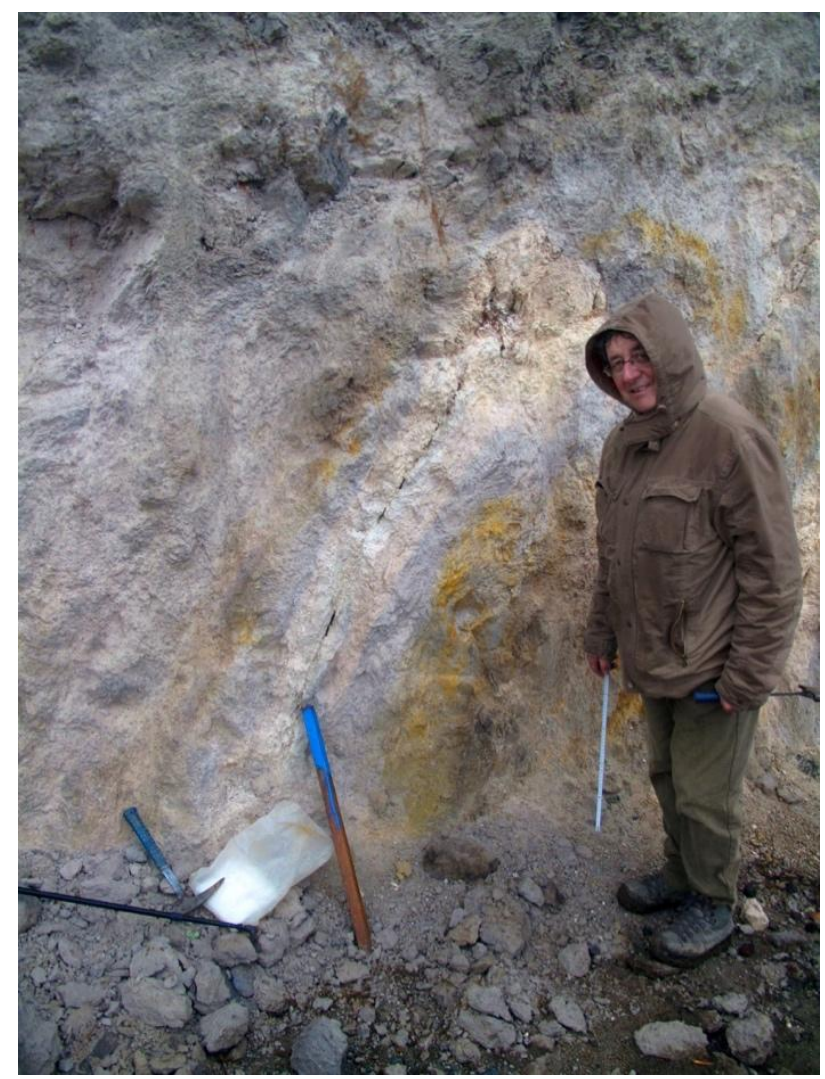

Figure 6 Field photograph illustrating the fumarolic activity along a fissure

The outcrop was located along the road leading to PdD summit, before reaching the upper cog railway station. The symmetric colour zonation on each side of the fissure illustrates the macroscopic changes of the trachyte in relation to fumarolic activity along the fissure.

(C) P. Boivin, March $18^{\text {th }}$ 2011)

\section{Chronology}

The dome construction was dated by thermoluminescence (Faïn et al., 1988), ${ }^{230} \mathrm{Th}^{-238} \mathrm{U}$ radioactive disequilibrium (Condomines, 1997) and radiocarbon (Miallier et al., 2010). In this study, two new ${ }^{14} \mathrm{C}$ dates, 9,555 $\pm 45 \mathrm{BP}$ and 9,540 $\pm 45 \mathrm{BP}$, were obtained (Table S1) on mm-sized charcoal fragments sampled in the BAF deposits at the southern base of the dome. Combining these new data with the previous ones, by means of a Bayesian approach which includes ${ }^{14} \mathrm{C}$ calibration (Lanos et al., 2015), an age of $11.0 \pm 0.2 \mathrm{ka}$ was obtained for the dome construction, the mean age of the late summit eruption being estimated at $10.70 \pm 0.15$ ka (Miallier et al., 2010). 


\section{Sampling and analytical techniques}

The formations identified above were sampled all around the volcano (over 200 samples, Figure 7) and analysed in thin section.

Various measurements were performed on many samples from this set (Supplementary Information C): connected porosity and density, modal analyses (Table S2), electron probe microanalyses and Raman analyses, major elements and radionuclide measurements (Table S3).

However, the present study is mainly focused on a smaller set of 30 samples that were analysed more specifically for trace elements, and $\mathrm{Sr}, \mathrm{Nd}$ and $\mathrm{O}$ isotopes (see analytical procedures in Supplementary Information C and Table S4). These samples are located in Figure 7 with a short description in Table 1.

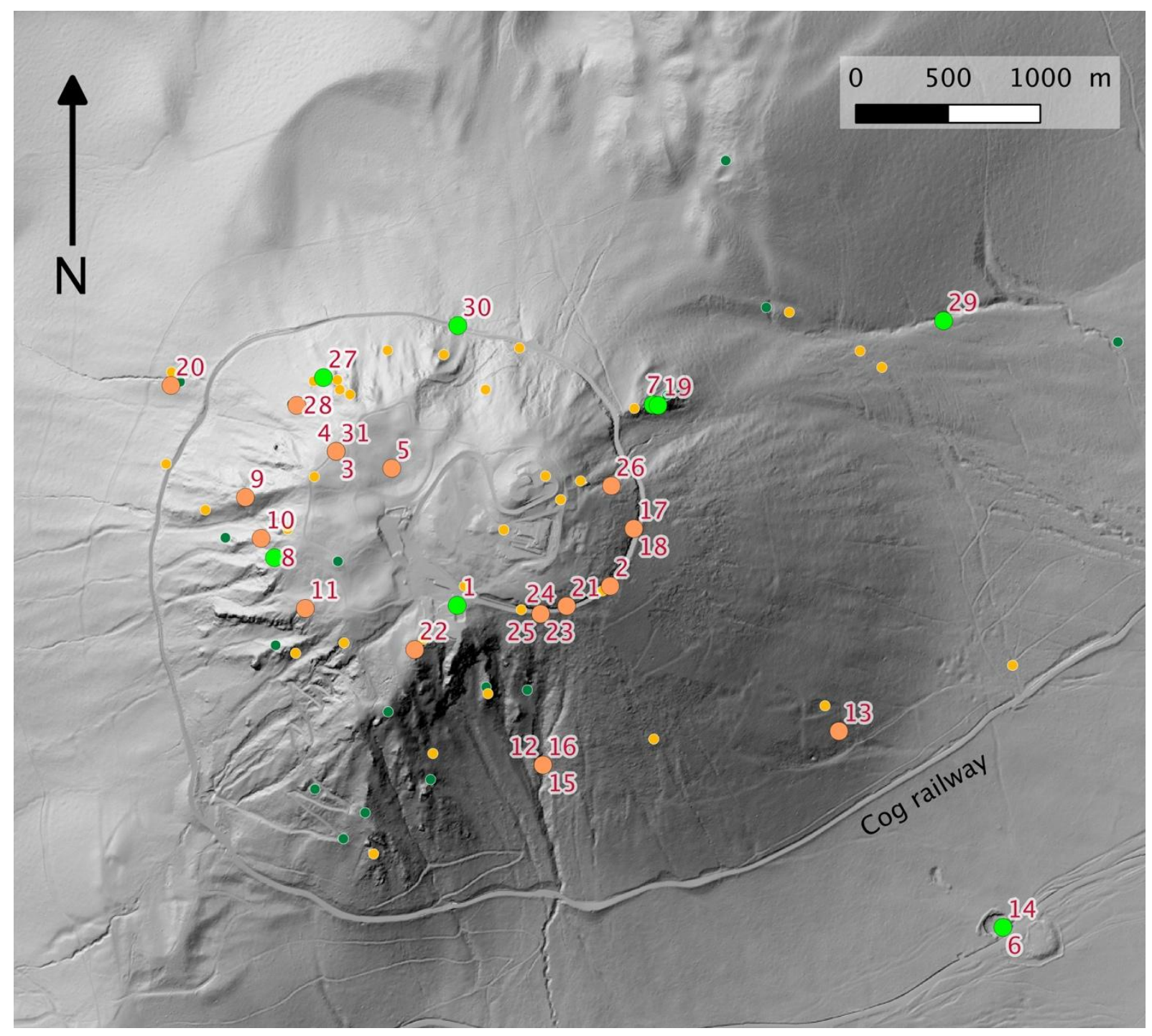

Figure 7 Location of PdD samples on the Lidar map 
Orange dots: bi-trachytes; green dots: cpx-trachytes. The bigger dots refer to the 30 samples more specifically analysed for geochemistry and isotopes. The associated numbers refer to the "index" numbers in Table 1. Note that cpx-trachytes are more abundant in the SW, absent in the SE and randomly distributed in the $\mathrm{N}$ of the volcano.

The 31 selected samples encompass the main groups of rocks identified on the basis of our field and petrographic investigations. They were analysed [some of them from Sforna (2008)] in order to better characterise the different trachytic facies. Bearing in mind that fumarolic activity largely affected the edifice, some conspicuously fumarolised samples were also analysed to assess the possible effect of these processes on the geochemical variations observed among apparently unaltered trachytes.

Bi-trachytes were sampled (1) on massive outcrops of the dome (C928, C931, PB1, PB2 and PB4), (2) as several-m sized blocks in the EU deposits (DM2, DM3, DM6 and 1105-2), (3) as decimeter-sized blocks (DM5) plus lapilli (C511, PB7, C511a and C663) in the pyroclastites of the CR formation, and finally (4) as lithic elements dispersed in a very fine grained matrix (DM1, C949 and C950) in the EU deposits. On the other hand, cpx-trachytes were sampled both on massive outcrops of the dome (DM4, C882, C915, PB3 and 1103-02) and as blocks (C806, C951, C963, PB5, and PB6) in the BAF deposits. The fumarolised samples consist of ashy samples from the EU deposits (PB15-1210-1, PB15-1210-2 and PB15-1210-3), located only a few centimeters apart from each other and close to a fissure, and a bi-trachyte with silicified biotite and groundmass (C943) from the dome.

The PB5 cpx-trachyte exhibiting unusual banded features was studied in more detail. The light (PB5C) and dark (PB5F) facies were separated by handpicking, but only grossly because of the intricate texture of the whole rock (WR) sample (Figure 8) preventing a better separation to be achieved. These two sub-samples were then crushed (about $200 \mathrm{~g}$ of gravels for each) and analysed separately, in addition to the bulk sample.

Most of these 31 samples were large ( 1 to $2 \mathrm{~kg}$ ) and macroscopically fresh. After removing their external parts, these samples were cut and crushed (jaw crusher and then agate mill on a quarted fraction of gravels). Exceptions are represented by the sub-samples described above and the lapilli of the CR formation for which much less material was available. Indeed, the initial amount of material for C511 and C663 was about $700 \mathrm{~g}$ and $150 \mathrm{~g}$, respectively. Besides, these lapilli were not as fresh as the other samples. Samples were sieved and the lapilli selected among the largest and freshest, in the 8-16 $\mathrm{mm}$ and $16-32 \mathrm{~mm}$ fractions for C511 and in the 8-32 mm fraction for C663. Three such sets of lapilli (C511, PB7 and 
C511a), resulting in 15-30 g of powder each, were analysed for C511 and only one (about 30 $\mathrm{g}$ of powder) for C663. Note also that for all fumarolised samples, the amount of starting material was only of the order of $600-800 \mathrm{~g}$.

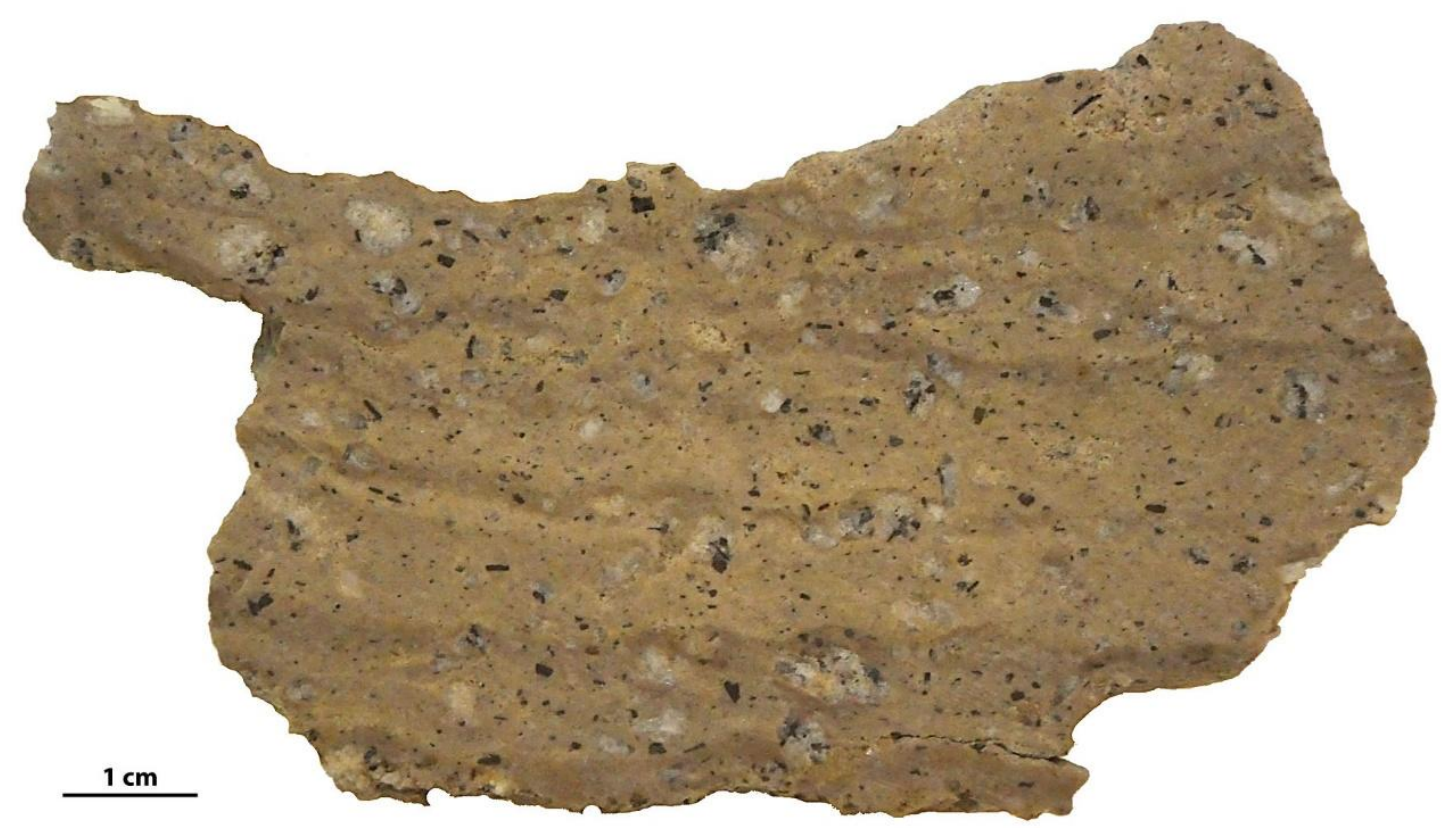

Figure 8 Banded features in PB5 cpx-trachyte

Photograph of a macroscopic section of the sample. White: feldspar phenocrysts; dark brown: biotite phenocrysts; brown, grey-brown, light brown: various bands.

\section{Petrography}

Since the $19^{\text {th }}$ century, the PdD lavas were more precisely described by using polarised light microscopy (Michel-Lévy, 1890; Bentor, 1954, for the most noteworthy). Over the last 50 years, the development of in situ micro-analyses allowed a better identification of minerals and the determination of their compositions (Boivin et al., 2017 and references therein). Nevertheless, until now, people have generally considered that PdD is so homogeneous that its composition can be summarized by a single typical sample. Here, the petrography of massive rocks was used to define the two trachytic facies which are also encountered, although with some variation, in pyroclastic deposits.

\subsection{Massive lava rocks}


These are mainly trachytes with feldspar and biotite phenocrysts $(>0.5 \mathrm{~mm})$ set in a groundmass consisting of plagioclase microliths and without identifiable glassy component (amounting to a few vol\% at most). Besides, as the liquid was close to the eutectic, the glass composition must be very close to that of the latest crystallised feldspar crystals making the recognition of this glass almost impossible with the electronic microprobe. The absence of residual glass in PdD massive trachytes was also mentioned by Boudon et al. (2015). Two lava facies were identified: a predominant K-oligoclase and biotite trachyte (bi-trachyte) and a K-oligoclase, biotite, sanidine and clinopyroxene trachyte (cpx-trachyte) (Figure 7).

A large variation of the maximum size and relative abundance of phenocrysts was observed over 30 thin sections of 28 samples (Table S2). However, the statistical comparison of the two main lava facies (Table 2) does not reveal any significant difference, except a higher cristallinity for the cpx-trachytes.
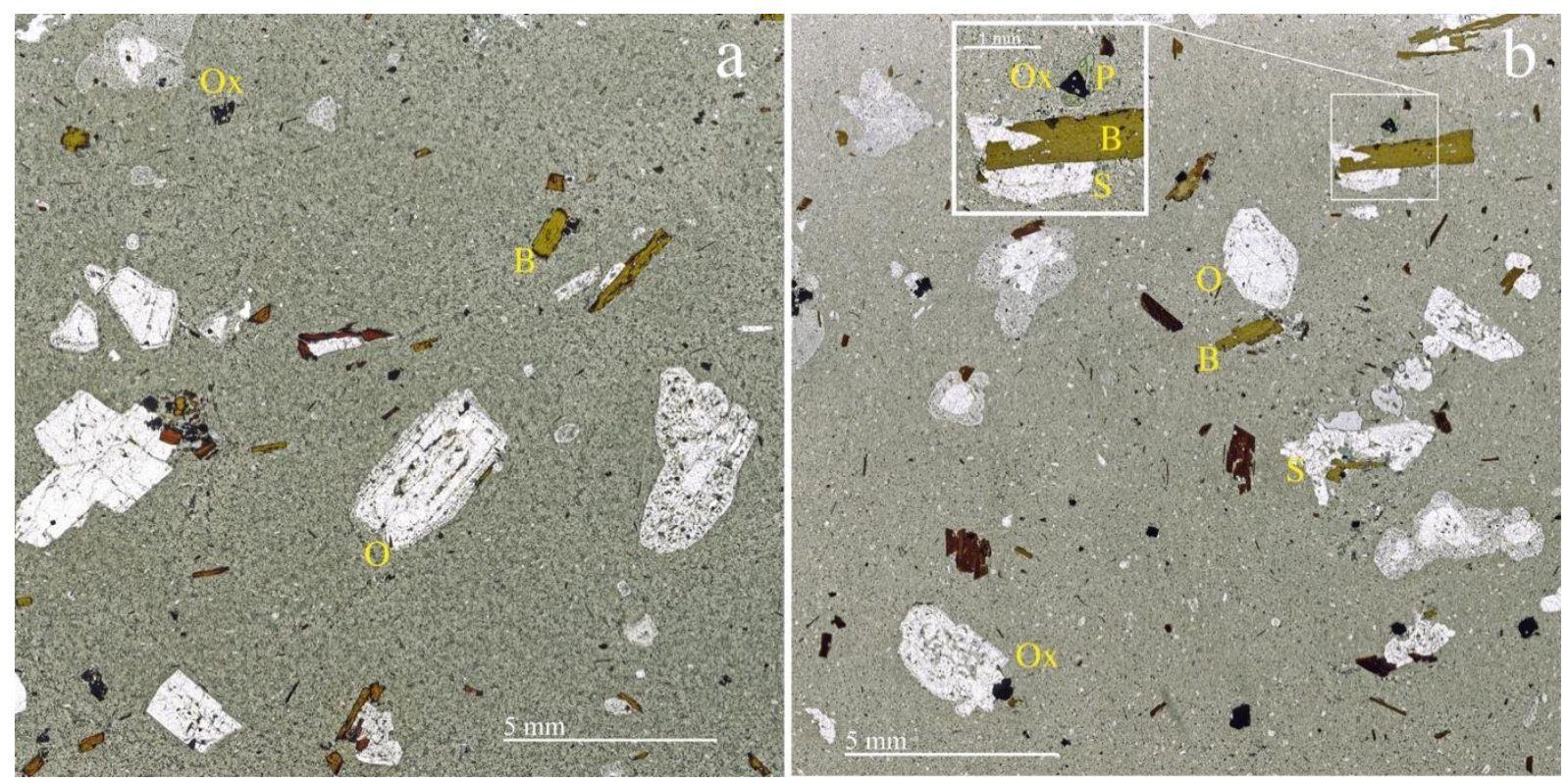

Figure 9 PdD lava facies

(a) Bi-trachyte (sample C931). (b) Cpx-trachyte (sample 1103-2). O: oligoclase; B: biotite; Ox: Ti-Fe oxide; S: sanidine; P: green cpx.

In the bi-trachytes, feldspar phenocrysts consist of plagioclase (oligoclase to potassic oligoclase). They are the most abundant ( 9 vol\%) and the largest and often form clusters in which euhedral crystals diverge suggesting a single center of crystallisation (Figure 9a). In most cases, these phenocrysts display an internal zone of variable thickness exhibiting disequilibrium textures (see Section 10.1.2.). Small euhedral biotite crystals are very often included, sometimes with apatite and Fe-Ti oxides. Biotite is the second phenocryst phase albeit much less abundant (1.5\%), with inclusions of prismatic apatite, Ti-magnetite and 
zircon. Fe-Ti oxides (magnetite and ilmenite) may form mm-sized crystal clusters with apatite. In one-third of the cases, biotite crystals outline the magma flow (trachytic texture). The groundmass mostly consists of anorthose feldspar microliths and Fe-Ti oxide grains. The porosity is highly variable (1-60\%) with a mean at about $20 \%$.

Cpx-trachytes display the same paragenesis as bi-trachytes, plus anorthose and sanidine phenocrysts, of similar size as oligoclase crystals, and small crystals (140-1,250 $\mu \mathrm{m})$ of green clinopyroxene. These cpx crystals are rather stubby (mean $L / 1=1.95$ for $n=105$ ), except in two samples (including PB5 which originality will be discussed later) in which elongated prisms $(\max \mathrm{L} / 1 \sim 5.5)$ are observed. Cpx crystals are often associated to apatite crystals and form clusters with Fe-Ti oxides (Figure 9b). The groundmass of cpx-trachytes looks similar to that of bi-trachytes, with additional sanidine microliths.

\subsection{Pyroclastic deposits}

The bi-trachyte lava facies occurs in two pyroclastic deposits.

The EU deposits are composed of up to $40 \%$ of 1 to $7 \mathrm{~mm}$ large, lithic elements of bitrachyte. These elements are rounded, with a core consisting of one or a few plagioclase \pm biotite phenocrysts encased in a holocrystalline groundmass comprising feldspar microliths, opaque minerals and interstitial silica. These elements are evenly distributed and packed in a homogeneous, friable, and very porous matrix consisting of anorthose feldspar microliths, clusters of cristobalite crystals and hematite grains.

The CR formation contains lapilli of fresh or fumarolised trachyte, fragments of basalts, scoria and xenoliths of basement rocks (Miallier et al., 2010). The fresh K-oligoclase and biotite trachytic elements, initially considered as juvenile magma of a phreatomagmatic eruption, do not exhibit any of the expected features (quenched bombs, dense lapilli, glass in the groundmass), suggesting instead a series of purely phreatic explosions. Petrographically, this remobilised lava facies is indistinguishable from the main bi-trachyte facies.

A cpx-trachyte paragenesis is observed in the trachytic fine-grained layers intercalated in the tuffs of the Nid de la Poule maar. These tuffs contain juvenile clasts of olivine and clinopyroxene-bearing trachybasalt, either quenched or not, black and red scoria from Petit Puy de Dôme and lithic elements of older basalts. The less contaminated (see Section 5) intercalated fine-grained layer is almost white and composed of trachytic elements: alkali feldspar, biotite, green clinopyroxene, clusters of feldspar microliths and silica (Figure 10). 
This paragenesis is so similar to that of PdD cpx-trachyte that it justifies the inclusion of this trachytic deposit in our study.
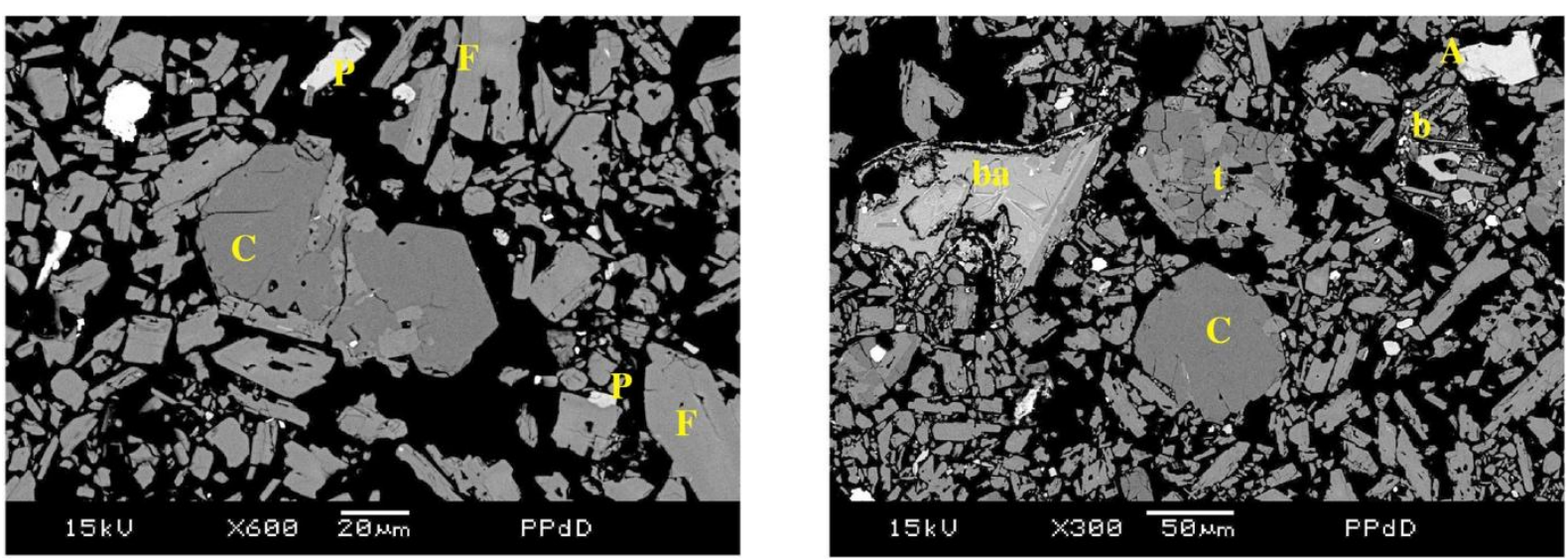

Figure 10 Back Scattered Electron (BSE) photographs [Scanning Electron Microscope $(\mathrm{SEM})]$ of the Nid de la Poule trachytic deposit

Trachytic volcanoclasts in the white tuff, Nid de la Poule maar (Figure 5). A: apatite; C: cristobalite; F: alkaline feldspar; P: clinopyroxene; b: basaltic ash; ba: altered basaltic ash; t: fragment of trachytic groundmass.

9.3. Mafic enclaves and silicic xenoliths

Very rare and small sized $(<10 \mathrm{~cm})$ xenoliths, with contrasted compositions, are also encountered in massive trachytes. In the course of this work, only three granitic xenoliths, more or less melted (buchite) were found along with about twenty mafic enclaves. The latter were interpreted either as cumulates, when they had a granular texture, or in terms of magma mixing, for the others (Arnaud, 1989; Arnaud et al., 1992). These xenoliths and enclaves were not considered in our study.

\subsection{Fumarolised rocks}

The syn-eruptive to late-stage fumarolic activity also produced specific petrographic facies. The transformations affecting both bi- and cpx-trachytes macroscopically consist in changes of colour, from grey to pink, red, yellow and white (Figure 6) and a chert-like appearance in the more advanced stages (see also Supplementary Information D). 
10. Mineralogy

This section is based on numerous mineral analyses performed during this study and complemented by data from Sourisseau (2007) and Sforna (2008). The whole data set is available in Supplementary Information E (Table S5). Only the mean compositions of minerals are reported in Table 3.

\subsection{Feldspars}

\subsubsection{Chemical zoning}

Feldspar phenocrysts and microliths from all the trachytes define a continuous chemical trend, from plagioclase (sodic andesine $\mathrm{An}_{32}$ ) to sanidine (Or${ }_{53}$ ) (Figure 11a). On the other hand, feldspars from mafic enclaves (Arnaud, 1989) display totally distinct compositions, much Anricher (labrador $\mathrm{An}_{59}$ - andesine $\mathrm{An}_{41}$ ).

More specifically, feldspar phenocrysts from bi-trachytes exhibit an oligoclase core $\mathrm{An}_{32-20}$ and rims enriched in $\mathrm{Na}-\mathrm{K}$ (K-oligoclase, $\mathrm{An}_{25-15} \mathrm{Or}_{19-25}$ ) (Figure 11b), whereas in cpxtrachytes additional rims or even whole crystals reaching sanidine compositions (Figure 11c) are observed.

Feldspar microliths from bi-trachytes mainly plot in the anorthose field but may reach sanidine $\left(\mathrm{An}_{23-1} \mathrm{Or}_{10-54}\right)$ compositions (Figure 11d). In cpx-trachytes, the range of compositions seems narrower $\left(\mathrm{An}_{16-1} \mathrm{Or}_{16-47}\right)$ but this is based on a smaller number of analyses available (Table 3). 


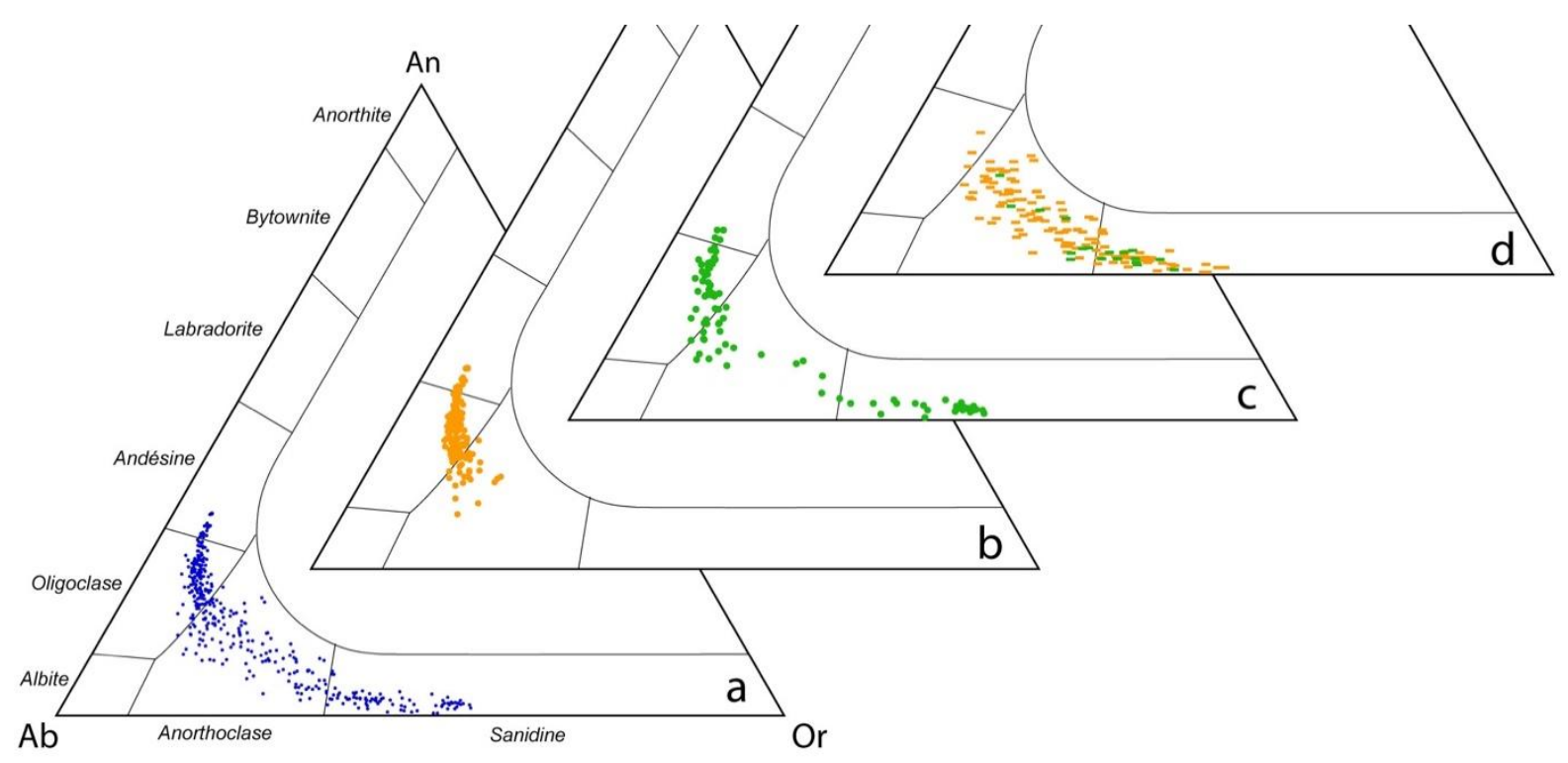

Figure 11 Feldspar compositions

(a) Whole data set. (b) Phenocrysts in bi-trachytes. (c) Phenocrysts in cpx-trachytes. (d) Microliths in bi-trachytes (orange) and in cpx-trachytes (green).

\subsubsection{Disequilibrium textures}

Numerous plagioclase phenocrysts from both bi- and cpx-trachytes display conspicuous fusion-recrystallisation zones concentric to their compositional zoning patterns (Figure 12). Such features were first described in CdP volcanic rocks as "cloudy zones" (e.g., Bentor, 1951; Poldervaart and Gilkey, 1954). They were later called "sieve textures" (e.g., Nelson and Montana, 1992). The development of these features induces numerous discontinuities in crystals growth with voids infiltrated by a highly porous groundmass, exhibiting the same minerals as the groundmasss of the sample itself, and where silica phase is crystallising (Figures 12a and 12b).

This transformation, naked-eye observed on outcrops, is a specific characteristic of PdD trachytes among CdP trachytes. Such features were variously interpreted in the literature as the result of (1) magma mixing, (2) convection, (3) differential movements (convective selfmixing) in the magma chamber during differentiation or (4) decompression (see Supplementary Information F for more details and references). These textures are usually accompanied by a strong contrast of feldspar compositions (An\%) between the sieved zones and the newly crystallised ones. This is never observed for PdD feldspars which do not display significant compositional variations between crystals zones. Thus, our preferred interpretation is that of differential movements in the magma chamber during differentiation 
resulting in the heterogeneous distribution of fluids. Indeed, classical phase diagrams show that pressure (especially $\mathrm{P}_{\mathrm{H} 2 \mathrm{O}}$ ) is a key parameter regarding the composition of a plagioclase crystallising at a given temperature. Small $\mathrm{P}_{\mathrm{H} 2 \mathrm{O}}$ variations have the potential to induce variations of plagioclase compositions (see references in Supplementary Information F), although in a restricted range, as observed for PdD feldspars. This interpretation would also be consistent with the recurrence of sieve-textured zones in a single crystal (Figures 12b).

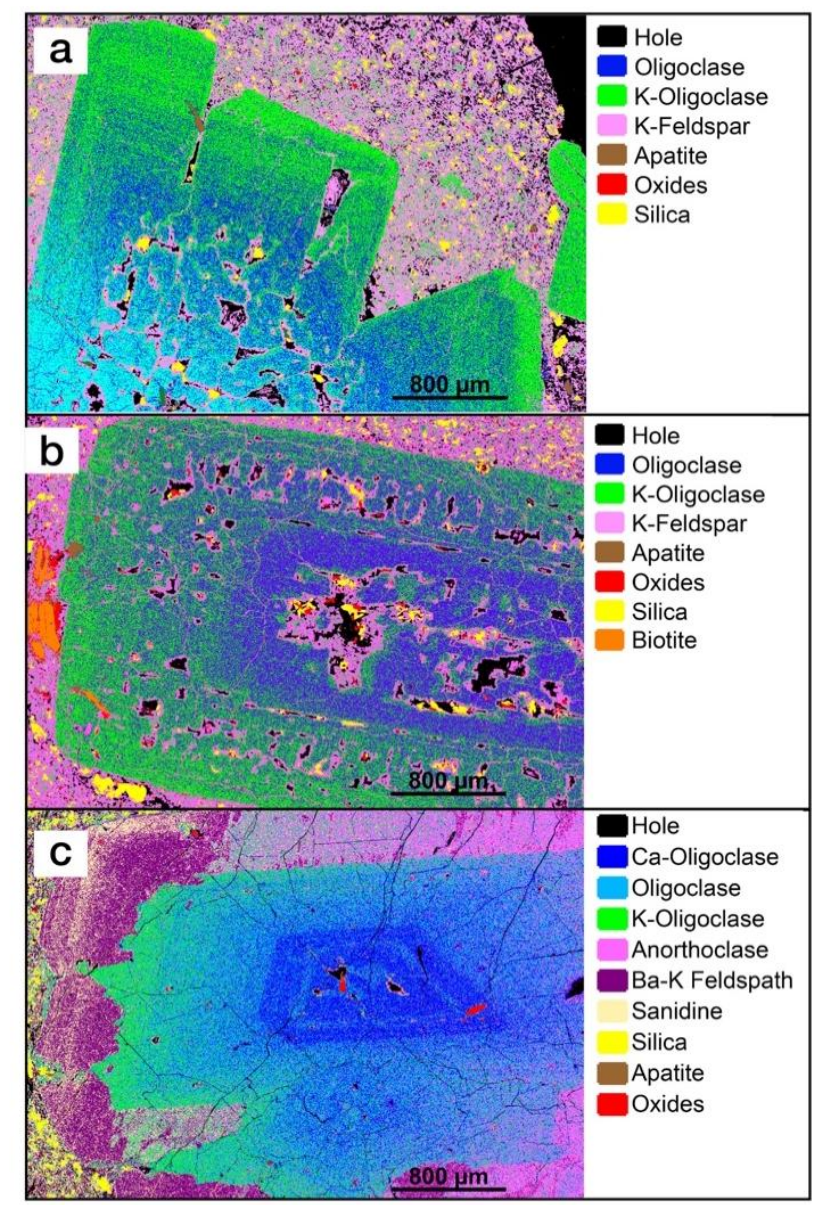

Figure 12 Chemical zoning and disequilibrium textures in plagioclase phenocrysts (SEM X images)

(a) Zoned plagioclase phenocryst in PB4 bi-trachyte. The core (oligoclase) displays a sieve texture, whereas the rim illustrates the growth of euhedral and zoned K-oligoclase. Silica, oxides and K-feldspar only occur in the groundmass. The light blue colour at the bottom left is an artefact of overexposure. (b) Zoned sieve-textured plagioclase phenocryst illustrating the development of recurrent sieve textures in a cpx-trachyte (PB08-2801-2) which does not belong to the main set. Biotite rims (left hand side of the picture) are oxidised. (c) Resorbed plagioclase in PB08-2801-2 cpx-trachyte. Zoned and highly resorbed oligoclase phenocryst used as a nucleus for the development of K-feldspar (anorthoclase and sanidine). 
Some plagioclase phenocrysts from the cpx-trachytes, including sample PB5 with banded features (Figure 8), display a highly resorbed core of oligoclase which served as a nucleus for the growth of K-feldspars (anorthose and sanidine) (Figure 12c). The first crystal growing layers are barium-rich illustrating the fact that $\mathrm{Ba}$, previously concentrated in the liquid, suddenly becomes compatible at the onset of K-feldspar crystallisation in cpx-trachytes.

\subsection{Biotite}

This mineral is ubiquitous, with crystals up to $1.5 \mathrm{~mm}$ long amounting to about $1 \mathrm{vol} \%$ of the phenocrysts. Smaller size crystals are also scattered in the groundmass. $[\mathrm{Mg}]$ ratios mostly range between 50 and 61 and $\mathrm{Si} / \mathrm{Al}$ ratios between 2 and 2.3 (Table 3). No chemical zoning is observed between cores and rims. Partial or even total oxidation (see Supplementary Information C) is commonly observed, with the growth of iron oxides starting from crystal rims and along cleavages (Figures 12b and S5), and making crystals opaque. Biotite in cpxtrachytes is enriched in iron (lower $[\mathrm{Mg}]$ ), $\mathrm{Mn}$ and silica (higher $\mathrm{Si} / \mathrm{Al}$ ) compared to biotite in bi-trachytes (Table 3).

\subsection{Clinopyroxene}

Green clinopyroxene, associated to sanidine, is the distinguishing feature of cpx-trachytes. Crystals are generally euhedral, sometimes with curved edges (Figure 9). The compositions are quite homogeneous (mean of $\mathrm{Ca}_{46 \pm 0.4} \mathrm{Mg}_{35 \pm 1} \mathrm{Fe}_{19 \pm 1}$ ), at the limit of diopside-augite compositions. The green colour may be related to the presence of $\mathrm{Fe}^{3+}$ resulting in $6.6 \mathrm{wt} \%$ aegirine component. Although these cpx compositions display the expected linear negative correlation between $\mathrm{Mg}$ and $\mathrm{Fe}$, no significant zoning is observed between crystal cores and rims. Mn variations between 2.14 and $3.14 \mathrm{wt} \%$ (mean at $2.65 \mathrm{wt} \%$ ) are not associated to any zoning but rather reflect inter-sample variations. No disequilibrium features were ever observed. Note that green clinopyroxenes from the Nid de la Poule deposits are among the most enriched in $\mathrm{Mn}(\mathrm{MnO}=3.04 \mathrm{wt} \%)$ whereas sample PB5, with macroscopic banding evoking magma mixing, exhibits both the Mn-richest and Mn-poorest (3.14 and $2.16 \mathrm{wt} \%$, respectively) cpx.

\subsection{Silica}


Raman spectroscopy analyses [Figure S6 and Boudon et al. (2015)] indicate that the silica phase is systematically cristobalite although it used to be considered as tridymite on the basis of crystals shape (Bentor, 1954). Such characteristics suggest a late-stage pseudomorphosis (Figure 13), but this process is not addressed here.

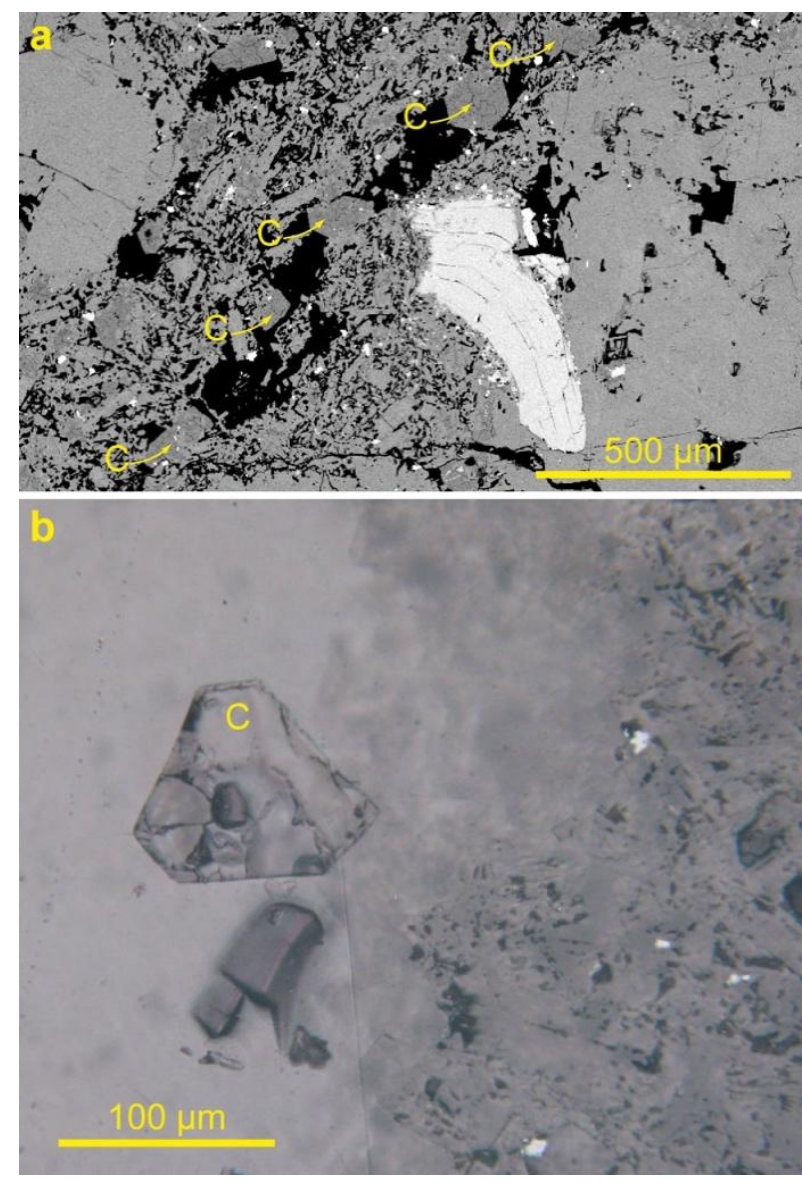

Figure 13 SEM and microscope photographs of cristobalite (C)

(a) Euhedral crystals in a fissure (BSE SEM) in PB3 cpx-trachyte. (b) Euhedral tridymite crystal pseudomorphosed into cristobalite (natural light microscope) in a bi-trachyte.

Analyses (Table 3) of various silica patches define (1) a main group $\left(\mathrm{SiO}_{2}\right.$ : $97.6 \mathrm{wt} \%, \mathrm{Al}_{2} \mathrm{O}_{3}$ : $1.8 \mathrm{wt} \%, \mathrm{Na}_{2} \mathrm{O}: 0.7 \mathrm{wt} \%$ ), and (2) a subordinate one with a larger spread, lower silica (mean $94.5 \mathrm{wt} \%$ ) and more secondary elements (Figure S7). The first group, mostly composed of euhedral crystals in fissures and voids, and sometimes replacing tridymite, suggests that synand post-eruptive fluids were present. The second group, consisting of patches in interstitial position, represents the end products of in situ fractional crystallisation.

10.5. Ti-magnetite, ilmenite and accessory minerals 
Fe-Ti oxides occur in all trachytes, generally as clusters or as scattered grains in the groundmass but also, occasionally, as euhedral phenocrysts. It is rarely possible to associate pairs of Ti-magnetite/ilmenite crystals to estimate the oxygen fugacity (Buddington and Lindsley, 1964; Lepage, 2003) of the magmatic system. Indeed, ilmenite is scarce and the large Ti-magnetite crystals are almost systematically reequilibrated at low temperatures, as attested by ilmenite exsolution, and possible oxidation at the contact with atmospheric oxygen (cf. biotite oxidation in Supplementary Information F). Such a process is common in lava bodies undergoing relatively slow cooling (Haggerty, 1976). Nevertheless, tentative estimates suggest that the $\mathrm{fO}_{2}-\mathrm{T}^{\circ} \mathrm{C}$ trajectory of trachytic magmas was intermediate between the NNO and HM buffer curves, in keeping with the sole value published so far (Maury et al., 1980a) and the $\mathrm{fO}_{2}$ buffer in alkaline series, classically slightly higher than NNO (Anderson, 1968; Maury et al., 1980b; Boivin and Bachèlery, 2009). This value was also used by Martel et al. (2013) to set their experimental conditions.

Accessory minerals consist of small zircon and apatite crystals, often associated to Ti-oxide clusters. Although very rare, sphene (titanite) was observed in four cpx-trachytes (Sourisseau, 2007).

\section{Geochemistry}

\subsection{Major and trace element geochemistry}

Major and trace element contents are given in Table 4 and analytical procedures described in Supplementary Information C. The range of variation of both major and trace element concentrations is very limited although it is obvious that the composition of the PdD trachyte cannot be defined based on a single sample as it used to be (Maury et al., 1980a; Martel et al., 2013; France et al., 2016).

\subsubsection{Major element data}

$\mathrm{SiO}_{2}$ variation among WR fresh samples is only 66-68.5 wt \%, $\mathrm{Al}_{2} \mathrm{O}_{3}$ 16-17.3 wt\%, $\mathrm{K}_{2} \mathrm{O}$ 4.6$5 \mathrm{wt} \%, \mathrm{Na}_{2} \mathrm{O}$ 5.6-6.1 wt $\%, \mathrm{TiO}_{2}$ 0.34-0.49 wt $\%, \mathrm{CaO}$ 1-1.7 wt $\%, \mathrm{P}_{2} \mathrm{O}_{5}$ below detection limit to $0.21 \mathrm{wt} \%$ and $\mathrm{MgO} 0.21-0.66 \mathrm{wt} \%$. However, it must be outlined that these ranges are 
much larger than for any other trachytic volcano from the CdP (Boivin et al., 2015; Miallier et al., 2017).

Despite some scatter, $\mathrm{Al}_{2} \mathrm{O}_{3}, \mathrm{MgO}, \mathrm{CaO}, \mathrm{P}_{2} \mathrm{O}_{5}$ and $\mathrm{TiO}_{2}$ overall decrease while $\mathrm{K}_{2} \mathrm{O}$ increases with increasing $\mathrm{SiO}_{2}$ (Figure 14). Furthermore, the two main groups of trachytes identified on the basis of their mineralogy are distinguished in these diagrams despite some overlap, bitrachytes displaying less evolved compositions and a larger dispersion. Although pyroclastites mostly plot in the field of bi-trachytes, in agreement with their mineralogy, lapilli from the CR formation and two blocks (DM2 and DM3) included in the EU deposits mostly plot outside the main trend, with lower $\mathrm{CaO}$ and $\mathrm{P}_{2} \mathrm{O}_{5}$ but higher $\mathrm{Al}_{2} \mathrm{O}_{3}$ contents than other samples with similar $\mathrm{SiO}_{2}$ contents. Note, however, that the massive bi-trachyte $\mathrm{C} 928$ lies within this group. Further, CR pyroclastites exhibit more evolved compositions than the EU deposits. The latter and two included blocks (DM6 and 1105-2) display the less evolved compositions encountered, together with PB2 (the least evolved one), also located on the eastern flank.

As already observed for their mineral compositions, PB5C and PB5F (sub-samples) have identical bulk compositions. 



Figure 14 Selection of some Harker diagrams for the various lava groups

Diagrams are given at two distinct scales to visualise the set of unaltered samples (right column) and fumarolised samples (left column). Numbers of some outstanding samples are given. $\mathrm{Bi}$ - and cpx-trachytes are distinguished although a significant dispersion is observed, 
especially among the less differentiated bi-trachytes. The compositions of fumarolised samples are very variable.

A large range of compositions is also observed among fumarolised samples which overall depart from the other samples with, more specifically, high to very high $\mathrm{SiO}_{2}$ contents (up to $76 \mathrm{wt} \%$ and even $98 \mathrm{wt} \%$ ). Large variations are also observed for most major elements such as $\mathrm{Al}_{2} \mathrm{O}_{3}$ (1-17.3 wt\%), $\mathrm{Fe}_{2} \mathrm{O}_{3}(0.2-4.6 \mathrm{wt} \%), \mathrm{CaO}(0.1-1.4 \mathrm{wt} \%), \mathrm{Na}_{2} \mathrm{O}(0.2-6.2 \mathrm{wt} \%)$ or $\mathrm{K}_{2} \mathrm{O}$ (0.3-5 wt\%), demonstrating that fumarolic activity was accompanied by large chemical changes (also Figure S4 in Supplementary Information D). Even the three samples taken close to a fissure, and very close to each other, display a large range of compositions (e.g., $\mathrm{Al}_{2} \mathrm{O}_{3}$ : 13.5-17.1 wt $\%, \mathrm{Fe}_{2} \mathrm{O}_{3}$ : 0.7-4.6 wt $\%, \mathrm{Na}_{2} \mathrm{O}: 4.8-5.8 \mathrm{wt} \%$ or $\mathrm{K}_{2} \mathrm{O}: 3.6-4.8 \mathrm{wt} \%$ ).

\subsubsection{Trace element data}

\subsubsection{Multi-element and REE patterns}

All samples display similar multi-element patterns with strong negative anomalies in $\mathrm{Rb}, \mathrm{K}$, $\mathrm{Pb}, \mathrm{P}$ and $\mathrm{Ti}$ and smaller ones in $\mathrm{Sr}$ and $\mathrm{Sm}$ (Figure 15a). These patterns also illustrate the higher enrichment in the most incompatible elements (but $\mathrm{Ba}$ ) in cpx-trachytes compared to bi-trachytes, consistent with their more evolved character and the onset of potassic feldspar fractionation (see Section 9.1. and Figure 12c). Cpx-trachytes are also generally less enriched in $\mathrm{Sr}, \mathrm{P}, \mathrm{Zr}$, Hf and $\mathrm{Ti}$, probably in relation with plagioclase, apatite, zircon and Fe-Ti oxides fractionation. The larger spread of compositions among bi-trachytes is further illustrated in these diagrams, as the affiliation of both $\mathrm{CR}$ and EU pyroclastite units to this group.

Despite global similar shape for Rare Earth Elements (REE) patterns (Figure 15b), the fractionation between LREE and HREE is variable within each group. The range of $(\mathrm{La} / \mathrm{Yb})_{\mathrm{N}}$ is 16.8-23.6 for bi-trachytes, including both groups of pyroclastites, versus 17.2-22.1 for cpxtrachytes (Table 4), further outlining the larger scatter among the former. Note that CR pyroclastite samples plus DM2 and DM3 blocks from the EU are significantly less enriched in $\Sigma$ REE than other EU samples, with $(\mathrm{La} / \mathrm{Yb})_{\mathrm{N}} 16.8-21.4$ versus $19.5-22.4$. Eu anomaly is absent or positive (CR pyroclastites except DM5 plus C928 and PB1, and DM2 and DM3 from the EU) in bi-trachytes, and absent or negative in cpx-trachytes. PB5C and PB5F subsamples remain indistinguishable based on their trace element compositions. 
Also, from Ba to Sm, the variation among fumarolised samples encompasses the full range of variation encountered among fresh samples. It is even larger for REE (La to Eu), with $(\mathrm{La} / \mathrm{Yb})_{\mathrm{N}}$ of $10-49.3$, Th and $\mathrm{Pb}$. They also exhibit the highest $\mathrm{Zr}$ and $\mathrm{Hf}$ contents and the lowest concentrations of more compatible lanthanides ( $\mathrm{Gd}$ to $\mathrm{Lu}$ ).


Figure 15 Spiderdiagrams for a selection of samples

(a) Representative multi-element and (b) REE patterns normalised to chondrites (Sun and McDonough, 1989). Colour codes refer to the distinct units: cpx-trachytes (green), bi- 
trachytes (orange), CR pyroclastites (pink), EU pyroclastite (purple), fumarolised samples (blue). The range of variation among fumarolised samples encompasses the full range of variation encountered among fresh samples.

\subsubsection{Binary trace element diagrams}

Th is a highly incompatible element which is more sensitive to the degree of evolution of magmas than $\mathrm{SiO}_{2}$ but, in felsic rocks, it may be affected by the fractionation of accessory minerals. However, the consistent variation between $\mathrm{Th}$ and $\mathrm{SiO}_{2}$ and the great similarity of $\mathrm{U}-\mathrm{Th}, \mathrm{Rb}$ - Th or $\mathrm{Rb} / \mathrm{Sr}-\mathrm{Th}$ variations $(\mathrm{Rb}$ and $\mathrm{Sr}$ being unaffected by accessory mineral fractionation) suggest that this effect is here very limited, allowing Th to be used as an index of differentiation. Although Th concentration range (15-21.8 ppm) remains fairly restricted, bi-trachytes (15-18.9 ppm) and cpx-trachytes (17.8-21.8 ppm) are again roughly distinguished in binary trace element diagrams such as U-Th (Figure 16). U and Th are also positively correlated, as expected for two highly incompatible elements during magmatic differentiation, but with a large dispersion indicating the involvement of additional processes than crystal fractionation, both within and between groups.

Compared with fresh rocks, fumarolised samples display a larger range of variation for Th (14.8-48.4 ppm) but almost none for $\mathrm{U}$ (4.3-4.9 ppm), which was probably buffered by the fluid phase. Besides, the range (15-22 ppm) displayed by the three samples collected next to a fissure encompasses that of all the undisturbed samples. 


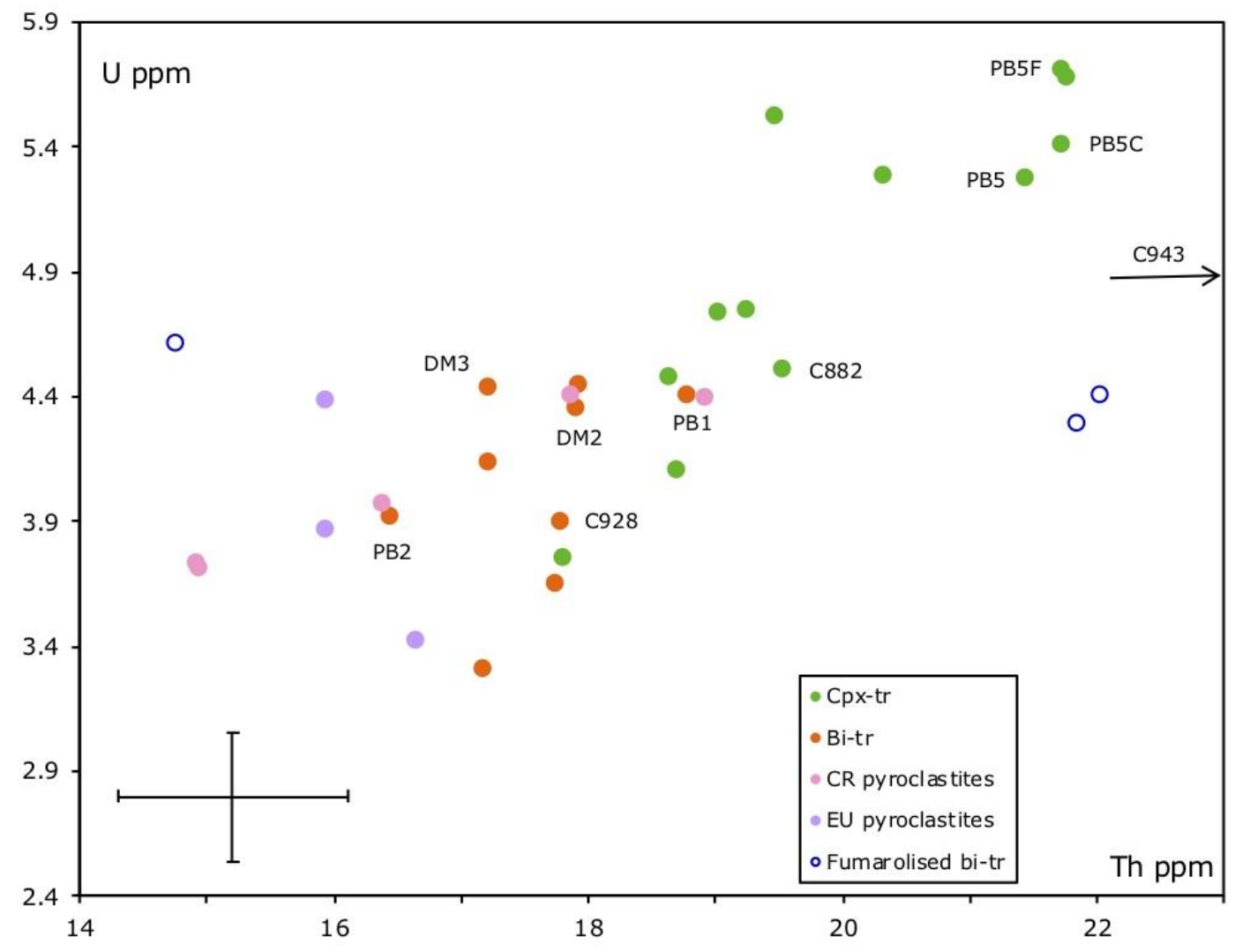

Figure $16 \mathrm{U}$ ppm versus Th ppm variation

C943 with $4.9 \mathrm{ppm}$ of $\mathrm{U}$ and a much higher Th content (48.4 ppm) than all the other samples is not plotted for the sake of clarity. Error bars (2SD) arise from the four replicate measurements of DM3 sample (Table S4) performed in the course of this study. Although U and Th are positively correlated, a large dispersion is observed suggesting the involvement of additional processes besides crystal fractionation.

\subsection{Radionuclides}

Similarly, a large variability is observed for the activities of both ${ }^{226} \mathrm{Ra}\left(51-76 \mathrm{~Bq} \cdot \mathrm{kg}^{-1}\right)$, belonging to the radioactive decay series of ${ }^{238} \mathrm{U}$, and ${ }^{232} \mathrm{Th}\left(60-92 \mathrm{~Bq} \cdot \mathrm{kg}^{-1}\right.$ ) (Table S3). This variation is larger than that observed in the six other CdP trachytic volcanoes (Boivin et al., 2015), including Grand Sarcoui which shares many characteristics with PdD (Miallier et al., 2017). As expected, a positive correlation is also observed between ${ }^{226} \mathrm{Ra}$ and ${ }^{232} \mathrm{Th}$ activities and the main groups previously described are identifiable (Figure 17). The Nid de la Poule trachytic deposits, which were not analysed for major and trace elements because of the poor quality of the samples (see Section 5.), were analysed for $\left({ }^{226} \mathrm{Ra}\right)$ and $\left({ }^{232} \mathrm{Th}\right)$. Both radionuclide activities are among the highest measured, confirming the highly evolved character of these products, as already shown by their cpx compositions (see Section 10.3.). 
Furthermore, these activities must be considered as minimum estimates because the trachytic component could not be completely separated from intimately associated, less evolved components (see Section 9.2.).



Figure $17\left({ }^{226} \mathrm{Ra}\right)$ versus $\left({ }^{232} \mathrm{Th}\right)$ variation

$\mathrm{Ra}$ and Th activities define a better correlation than $\mathrm{U}$ and Th concentrations. CR pyroclastites from PdD summit exhibit the least evolved bi-trachyte compositions whereas Nid de la Poule trachytic deposits display the most differentiated cpx-trachyte compositions.

Note that the sample groups (especially CR) and the positive correlation appear better defined with ${ }^{226} \mathrm{Ra}$ and ${ }^{232} \mathrm{Th}$ activities than with $\mathrm{U}$ and Th concentrations (Figure 16). This is due to the smaller uncertainties on activity measurements and to the fact that $\mathrm{Ra}$ and $\mathrm{U}$ elements behave differently. Error bars are 2SD statistical and systematic uncertainties.

11.3. Radiogenic and stable isotope geochemistry

11.3.1. Radiogenic ( $\mathrm{Sr}$ and $\mathrm{Nd})$ isotopes

The range of radiogenic isotope variation is very restricted (Table 5, Figures 18a and 18b). 
${ }^{143} \mathrm{Nd} /{ }^{144} \mathrm{Nd}$ isotope ratios $(0.512732$ to 0.512745$)$ variation is insignificant as it is of the same order of magnitude as the 2SD on the mean of 22 JNdi-1 standard measurements (see Supplementary Information C for analytical procedures), with the exception of PB7 which is significantly more radiogenic (0.512796).

Although broadly homogeneous, $\mathrm{Sr}$ isotopes allow to roughly distinguish the two main lava facies: bi-trachytes (including CR and EU pyroclastites) with lower ratios $(0.704491$ < $\left.{ }^{87} \mathrm{Sr} /{ }^{86} \mathrm{Sr}<0.704515\right)$, and cpx-trachytes with more variable and slightly higher ratios $\left(0.704523<{ }^{87} \mathrm{Sr} /{ }^{86} \mathrm{Sr}<0.704570\right)$. Indeed, only one cpx-trachyte (PB3) has a Sr isotope ratio (0.704498) similar to bi-trachytes (Figure 18b). Besides, PB7 (CR formation) is less radiogenic $(0.704463)$ than all the other samples, in line with its more radiogenic $\mathrm{Nd}$ isotope signature (Figure 18a).

The peculiar distribution of Sr isotope signatures in PB5 cpx-trachyte must also be outlined. While PB5 and PB5C exhibit similar ratios (0.704558 and 0.704567, respectively), PB5F displays a significantly higher value (0.704637), corresponding to the most radiogenic signature measured in this study.

Interestingly, both $\mathrm{Sr}$ and $\mathrm{Nd}$ isotope ratios of the few analysed fumarolised samples are similar to those of non fumarolised samples, suggesting either that the magmatic system remained closed regarding $\mathrm{Sr}$ and $\mathrm{Nd}$ isotopes, or that the mass balance between fumarolic fluids and rocks could not result in a variation of isotopic ratios in the latter. 

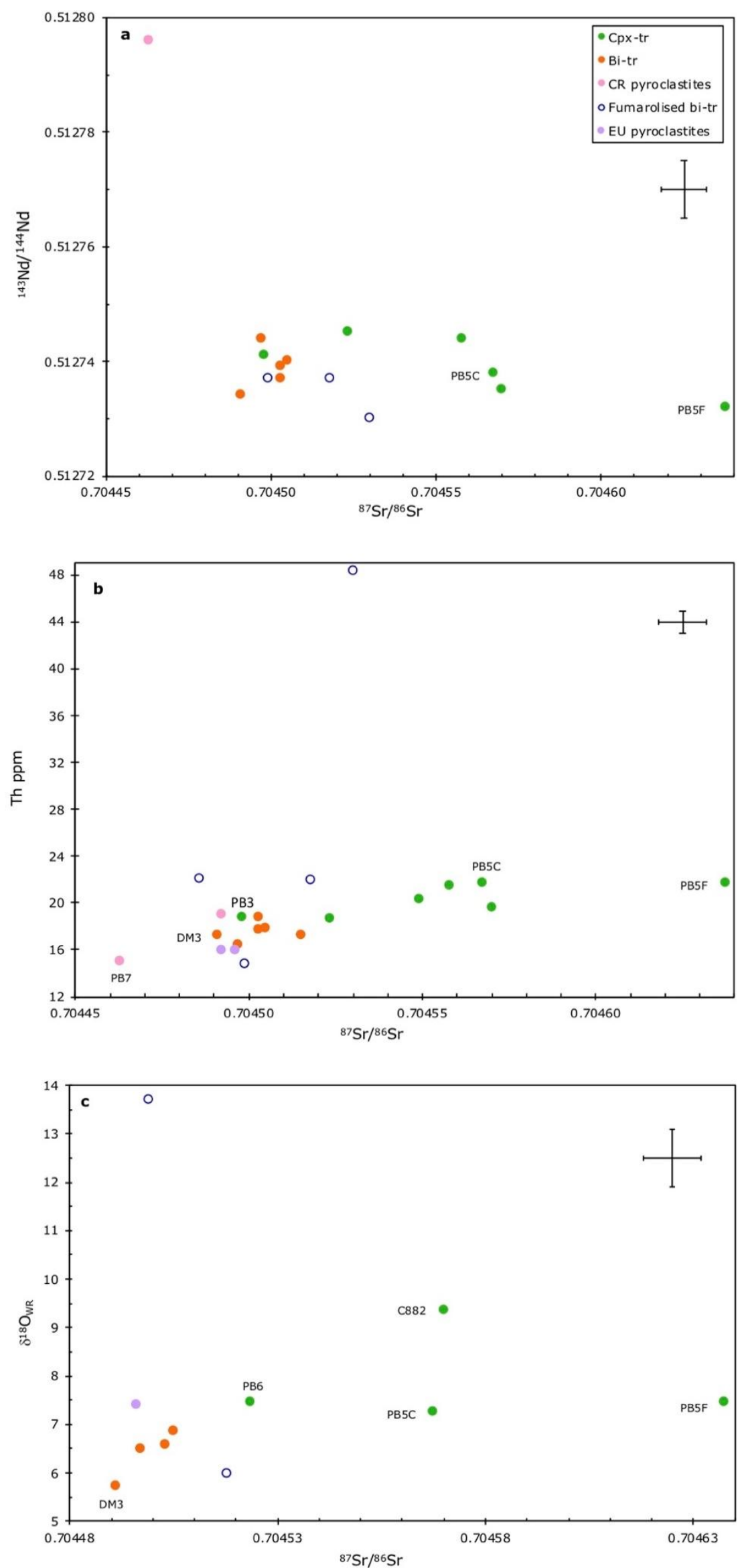

Figure 18 Radiogenic and stable isotope diagrams 
(a) ${ }^{143} \mathrm{Nd} /{ }^{144} \mathrm{Nd}-{ }^{87} \mathrm{Sr} /{ }^{86} \mathrm{Sr}$, (b) $\mathrm{Th} \mathrm{ppm}-{ }^{87} \mathrm{Sr} /{ }^{86} \mathrm{Sr}$ and (c) $\delta^{18} \mathrm{O}_{\mathrm{WR}}(\% \mathrm{VSMOW})-{ }^{87} \mathrm{Sr} /{ }^{86} \mathrm{Sr}$ variation. Error bars for isotopic ratios are the 2SD given in Supplementary Information C whereas for Th, it is as in Figure 16. ${ }^{143} \mathrm{Nd} /{ }^{144} \mathrm{Nd}$ variation is insignificant except for PB7 CR sample. Bi- and cpx-trachytes are roughly distinguished through ${ }^{87} \mathrm{Sr} /{ }^{86} \mathrm{Sr}$ and cpx-trachytes display slightly higher $\delta^{18} \mathrm{O}_{\mathrm{WR}}$. Fumarolised samples have indistinguishable $\mathrm{Sr}-\mathrm{Nd}$ signatures and display a large range of $\delta^{18} \mathrm{O}_{\mathrm{WR}}$.

\subsubsection{O isotopes}

In contrast with $\mathrm{Sr}-\mathrm{Nd}$ isotopes, a large range of $\delta^{18} \mathrm{O}$ is observed (Table 5), from 5.7 to 13.7 \%o (Figure 18c) [see Supplementary Data Information C for analytical procedure]. Although only eleven samples were analysed, the cpx-trachytes seem to have $\delta^{18} \mathrm{O}$ slightly higher and more variable (7.2-9.4 \%) than massive bi-trachytes (5.7-6.9 \%o). C950 (EU pyroclastite) displays a slightly higher $\delta^{18} \mathrm{O}(7.4 \%$ o) than the other bi-trachytes. Furthermore, the two fumarolised samples analysed, associated to the same fissure, display one of the lowest $\delta^{18} \mathrm{O}$ (6\%) and the highest (13.7\%) values, suggesting that fumarolised samples have a large range of oxygen isotope compositions, as already observed for most major and trace elements.

\section{Discussion}

Our field, geomorphological, petro-mineralogical, geochemical and isotopic data bring new constraints on the genesis of PdD magmas and on the processes involved in the development of the volcano, allowing us to revisit the model of this edifice growth.

\subsection{Magmatic differentiation, magma mixing and crustal contamination}

In this section, only those processes which occurred in the uppermost crustal magma chamber associated to $\mathrm{PdD}$ will be evaluated, without consideration of the deeper crustal history of magmas which is out of the scope of this paper. Despite some overlap between groups, major and trace element compositions document an increasing degree of differentiation, from PB2 bi-trachyte and the EU pyroclastites to the rest of bi-trachytes (including the CR pyroclastites) and then cpx-trachytes. Besides, our mineralogical and radioactive nuclide data reveal a genetic link between the trachytic deposits of the Nid de la Poule and PdD cpx-trachytes, the 
former exhibiting one of the most evolved cpx-trachyte compositions. These trachytic volcanoclasts reached the surface after the eruption of $\mathrm{PdD}$, due to the explosive activity of a maar on Petit Puy de Dôme (see Section 12.4.2.).

However, the dispersion observed in Harker diagrams, both for the whole data set and within each group, suggests that crystal fractionation alone cannot account for the differentiation among these trachytes. This is further illustrated by the large scatter in binary trace element diagrams involving either highly incompatible elements with very similar behaviour during differentiation (e.g., U, Th, La), or less incompatible elements (e.g., Sr, Nb, Zr, Y), including elements sensitive to plagioclase and zircon fractionation in evolved compositions (see Section 11.1.2.2.) (Figures 16 and 19). Sr isotope ratios (Figure 18b), higher and more variable in cpx-trachytes than in bi-trachytes, also require the involvement of additional processes.
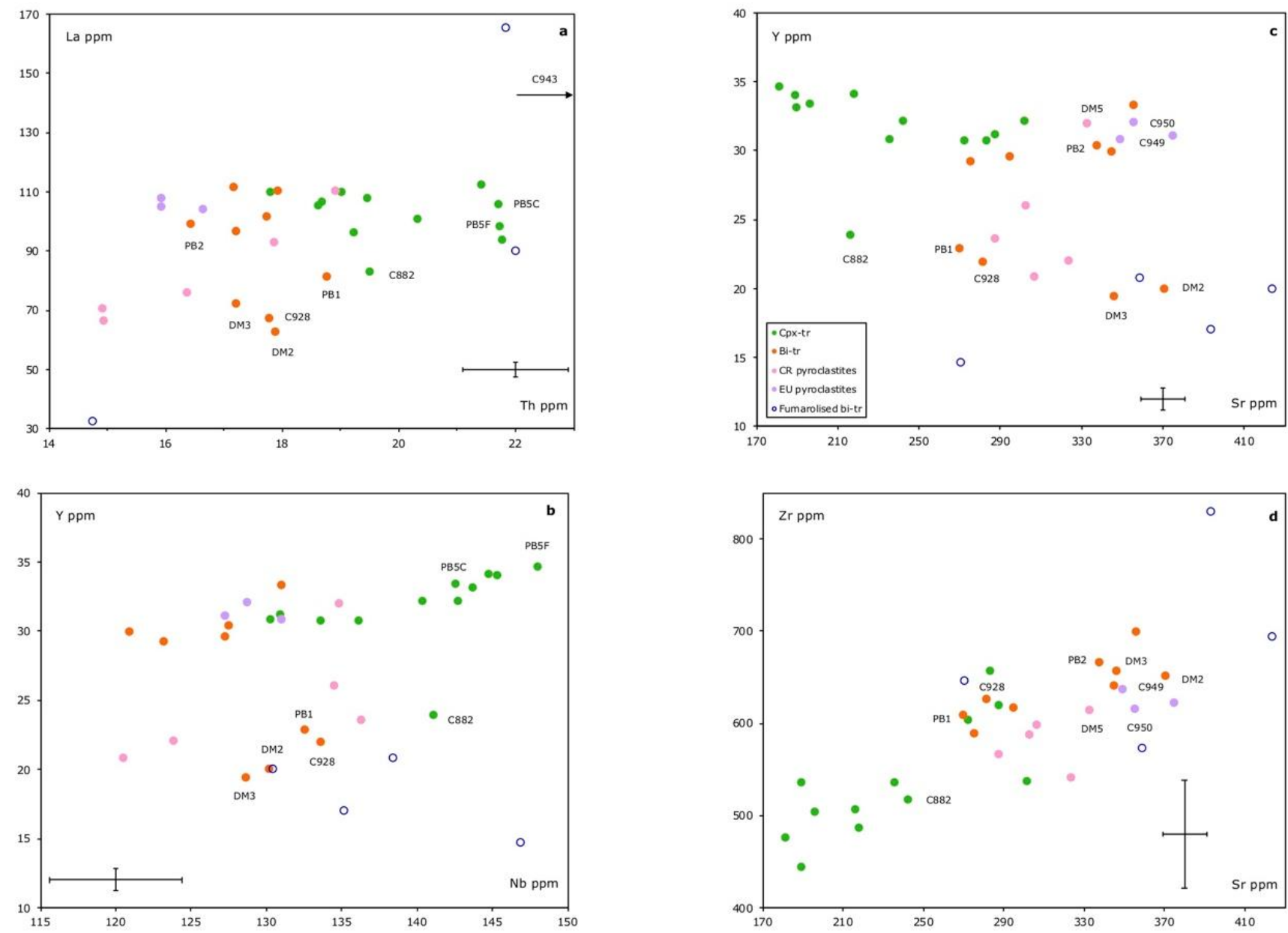

Figure 19 Binary trace element diagrams

(a) La versus Th; (b)Y versus Nb; (c) Y versus Sr and (d) $\mathrm{Zr}$ versus Sr. Error bars (2SD) as in Figure 16. The dispersion observed with both highly incompatible (Th, La) and less 
incompatible ( $\mathrm{Sr}, \mathrm{Nb}, \mathrm{Zr}, \mathrm{Y}$ ) trace elements suggests the involvement of additional processes besides crystal fractionation during differentiation. Note the group with lower La and Y contents.

The outstanding macroscopic banding (Figure 8) and distinct mineralogical characteristics of PB5 suggest the involvement of magma mixing processes. Specifically, it is in this sample that the most extreme cpx compositions (the whole range of Mn content) are encountered. Also, plagioclase phenocrysts displaying resorbed/growth features coexist with homogeneous crystals, indicating the existence of inherited crystals and thus the interaction of distinct magmas.

Although granite and buchite xenoliths are very rare in cpx-trachytes (and absent in bitrachytes), crustal contamination could have been involved as both the magma chamber and conduit are located in the granitic basement. The banded sample PB5 is one of the three most evolved cpx-trachytes of this study and also the most radiogenic in $\mathrm{Sr}$, with significant intrasample $\mathrm{Sr}$ isotope heterogeneity. However, it does not display any petrological or mineralogical evidence of crustal contamination. Moreover, the Sr isotope heterogeneity contrasting with $\mathrm{Nd}$ isotope homogeneity is incompatible with bulk assimilation of the country-rocks and would rather suggest selective crustal contamination or the interaction with Sr-rich fluids with a radiogenic signature. We suggest that late magmatic fluids associated to the more evolved magmas (cpx-trachytes) and interacting with the granitic country-rocks at the roof and walls of the magma chamber and/or conduit would have favoured the preferential destabilisation of the ca. 300 Ma old biotite of the local basement, characterised by highly radiogenic ${ }^{87} \mathrm{Sr} /{ }^{86} \mathrm{Sr}$ ratios (1.06 to 3.67 , Vialette, 1962). Such fluids, highly radiogenic in $\mathrm{Sr}$, would account for the observed decoupling between $\mathrm{Sr}$ and $\mathrm{Nd}$ isotopes and the fact that cpxtrachytes, the most evolved and first emitted magmas (see Section 12.4.1.), display a more radiogenic $\mathrm{Sr}$ isotope signature. Indeed, cpx-trachytic magmas could have been variably contaminated in that way, possibly at the top of the magma chamber but especially in the magma conduit, and then imperfectly mixed because of their high viscosity due to their evolved composition. Such contamination-mixing process would be compatible with all our petrological, mineralogical and $\mathrm{Sr}$ isotope data and the dispersion of major and trace element data. Among our samples, banded sample PB5 would give the best illustration of such a process, probably in the magma conduit (see Section 12.4.1.). Mechanical mixing and shearing between magma batches happening during ascent in magma conduits has also been 
reported for andesitic domes (e.g., Montserrat, Burgisser et al. 2010). In this case, magmas were only distinguished through their state of degassing and crystallisation.

At first sight, the small (except C882) increase of $\delta^{18} \mathrm{O}$ in cpx-trachytes (7.2-7.4\%o) compared to bi-trachytes (5.7-6.9\%) (Figure 18c) could simply be explained by an increasing degree of differentiation. However, this is not supported by the $\delta^{18} \mathrm{O}-\mathrm{SiO}_{2}$ relationships (Figure 20). Indeed, although PB6, PB5C and PB5F display slightly higher $\delta^{18} \mathrm{O}$ than PB1 and C928, their $\mathrm{SiO}_{2}$ contents are almost identical. Furthermore, PB6, PB5C and PB5F, though almost identical for their $\delta^{18} \mathrm{O}$, display significantly different ${ }^{87} \mathrm{Sr} /{ }^{86} \mathrm{Sr}$ ratios (Figure 18), indicating a decoupling of $\mathrm{O}$ and $\mathrm{Sr}$ isotopes and thus a complex interplay of crustal contaminationmixing, and probably fluid interactions during the genesis of the cpx-trachytes.

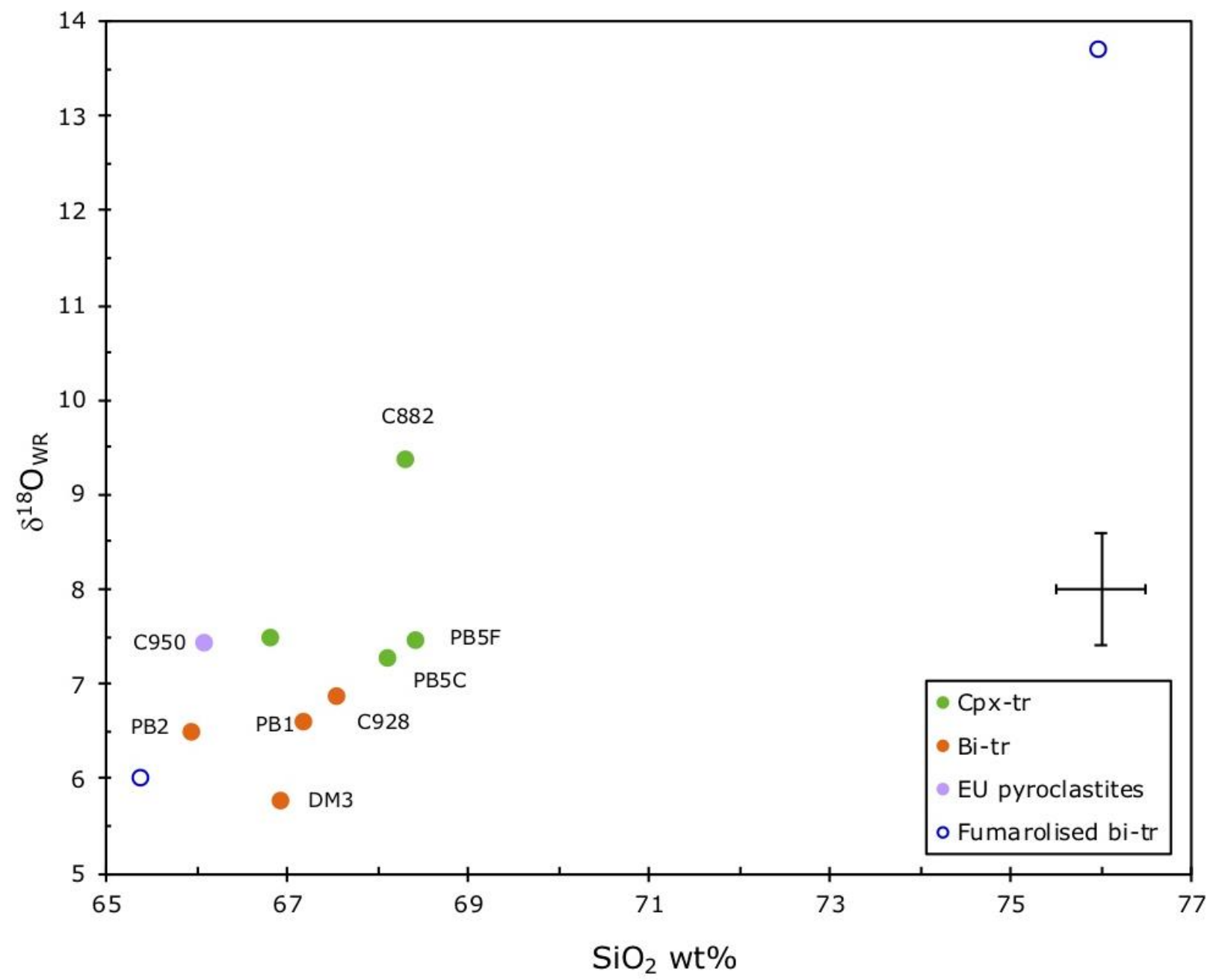

Figure $20 \delta^{18} \mathrm{O}_{\mathrm{WR}}\left(\%\right.$ VSMOW) versus $\mathrm{SiO}_{2}$ wt $\%$ variation

Error bars refer to the $1 \mathrm{SD}$ of $\delta^{18} \mathrm{O}$ given in Supplementary Data Information $\mathrm{C}$ and a $2 \mathrm{SD}$ for $\mathrm{SiO}_{2} \mathrm{wt} \%$ deliberately slightly larger (0.5) than that given in Table S4. The small increase of $\delta^{18} \mathrm{O}_{\mathrm{WR}}$ in cpx-trachytes compared to bi-trachytes is not related to an increasing degree of 
differentiation. The variation among bi-trachytes and the high $\delta^{18} \mathrm{O}_{\mathrm{WR}}$ of $\mathrm{C} 882$ do not support an exclusive control by crystal fractionation and crustal contamination-mixing processes.

The homogeneous $\mathrm{Sr}$ isotopes of bi-trachytes suggest that these magmas were probably less, or not, affected by contamination/mixing processes. Both the lower ${ }^{87} \mathrm{Sr} /{ }^{86} \mathrm{Sr}$ and the absence of crustal xenoliths in this facies would also be consistent with the fact that the bi-trachytes were emitted after the cpx-trachytes, and were potentially less affected by crustal contamination at the magma chamber roof/walls and/or during magma ascent. Although PB1, PB2 and C928 bi-trachytes display almost identical $\delta^{18} \mathrm{O}$ (Figure 20), the lower and higher values of DM3 and C950, respectively, over the same range of $\mathrm{SiO}_{2}$, do not support an exclusive control by crystal fractionation.

\subsection{A distinct group}

The anomalous character of some samples, namely the cpx-trachyte C882 with a much higher $\delta^{18} \mathrm{O}$ than expected and DM3 and C950, suggests the involvement of additional processes than crystal fractionation, crustal contamination and magma mixing (probably located in the magma conduit) in their genesis.

The anomalous character of some samples is also illustrated in the $\mathrm{Y}-\mathrm{Sr}$ and $\mathrm{Zr}$-Sr diagrams (Figures 19c and 19d) where double trends are observed. In the $\mathrm{Zr}$-Sr diagram, one trend is displaced toward higher $\mathrm{Sr}$ contents at similar $\mathrm{Zr}$ contents whereas in the Y-Sr diagram, one trend is displaced toward lower Y contents at similar Sr contents.

Bi-trachytic samples PB2, C949, C950, DM2, DM3, DM5 belonging to the high Sr group in the $\mathrm{Zr}$-Sr diagram and having similar $\mathrm{Sr}$ isotope ratios (the five analysed samples), do not belong to the same trend in the Y-Sr diagram. Indeed, DM2 and DM3 plot on the lower Y-Sr trend, with significantly lower Y contents. Note that two other bi-trachytic samples (PB1 and C928) and one cpx-trachyte (C882) belonging to the low Sr-Zr trend also plot on this low YSr trend. This distinct, low Y-Sr group is also identified in the Y-Th and Y-Nb diagrams (Figures 21 and 19b) where the other samples define an overall positive correlation. This group consists of massive bi-trachytes (PB1 from a spine and C928 from a crest), bi-trachytic blocks from the dome having a brecciated groundmass (DM2 and DM3) and embedded in the EU pyroclastite, a massive cpx-trachyte from a northeastern crest (C882) and all the CR pyroclastites. It is also recognisable in the La-Th diagram (Figure 18a) due to its lower La contents. 


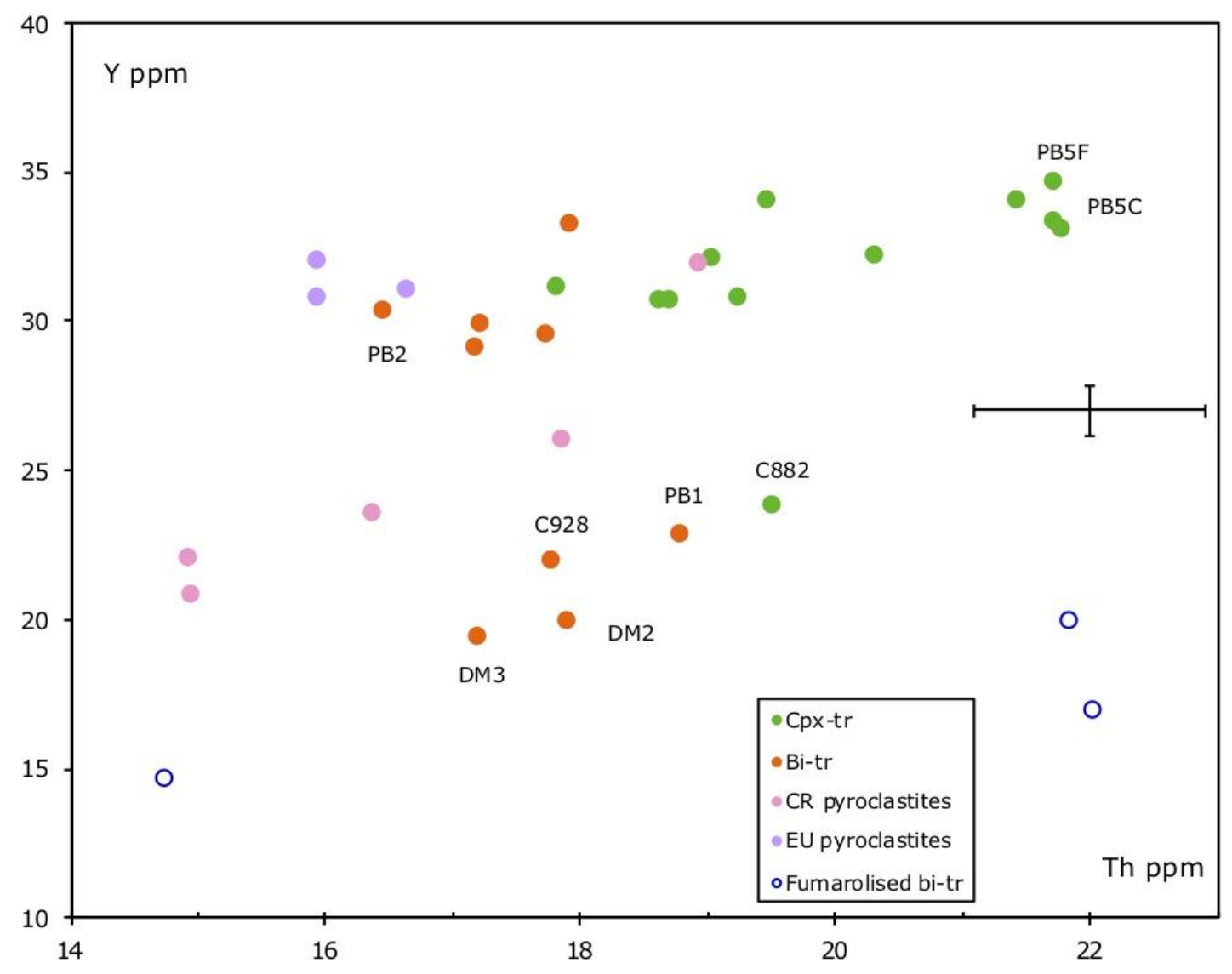

Figure 21 Y versus Th variation

Error bars as in Figure 19.

The low Y group is distinguished as in Figure 19. It is also characterised by low REE contents and ratios such as $\mathrm{Sm} / \mathrm{Yb}$, in addition to its lower $\mathrm{CaO}, \mathrm{P}_{2} \mathrm{O}_{5}$ and higher $\mathrm{TiO}_{2}$ contents.

This group is actually well identified with all the REE and $\mathrm{Y}$, and also with some REE ratios such as $\mathrm{Sm} / \mathrm{Yb}$, which are lower than in the rest of samples. Although less conspicuous, the distinction can also be made with major elements, mainly $\mathrm{CaO}$ but also $\mathrm{P}_{2} \mathrm{O}_{5}$ and $\mathrm{TiO}_{2}$ (Figure 14), these samples exhibiting lower $\mathrm{CaO}$ and $\mathrm{P}_{2} \mathrm{O}_{5}$ (except $\mathrm{PB} 1$ ) but higher $\mathrm{TiO}_{2}$ contents for similar $\mathrm{SiO}_{2}$ contents. In the $\mathrm{CaO}$ versus $\mathrm{SiO}_{2}$ diagram, they actually define a secondary trend of differentiation, parallel to the first one but with lower $\mathrm{CaO}$ concentrations. The fact that the samples from this marginal group belong to the various magmatic groups identified in this study suggests that their features could be related to processes other than purely magmatic, such as tardimagmatic (fumarolic activity?) or secondary (meteoric alteration?) processes.

12.3. Alteration versus fumarolic activity 


\subsubsection{Alteration}

The 27 non fumarolised samples were selected for both their representativity and freshness (macroscopic and microscopic examination). Only CR samples for which little material was available were of lower quality as they consist of lapilli ejected during a late phreatic eruption, in relation to a hydrothermal system. In thin section, biotite is generally largely oxidised and a yellow to green pervasive alteration of the groundmass is observed, outlining that these samples suffered alteration. We decided to analyse them, however, as this specific unit, sampled during layout works on PdD summit, does not crop out elsewhere on the volcano.

The freshness of the samples may also be evaluated through their LOI, which is usually impossible with basalts because of the presence of $\mathrm{Fe}^{2+}$ affecting the LOI measurements. Two thirds of our samples display LOI $<0.4 \mathrm{wt} \%$ and only four samples have LOI $>0.8 \mathrm{wt} \%$ (Table 4, Figure 22a). Not surprisingly, three CR samples are clearly apart with LOI of 0.85 to $1.1 \mathrm{wt} \%$ whereas fumarolised samples have values of 0.6 to $2.4 \mathrm{wt} \%$, the former value overlapping values measured in the non fumarolised samples. Note that $\mathrm{C} 806$, with one of the two highest LOI (1.05 wt\%), does not belong to the marginal group of samples mentioned above whereas PB7 and DM2 from this group display LOI $<0.4 \mathrm{wt} \%$. Samples from the marginal group plotting among the other samples generally display the highest LOI at a given Th content. However, two other samples (C931 and C963) also define this upper LOI limit (with either $\mathrm{Th}$ or $\mathrm{SiO}_{2}$ ). A similar pattern is observed in many other LOI-x diagrams, $\mathrm{x}$ being either a potentially highly mobile element during alteration (U, K) [Figure 22b] or a reputed immobile element such as the REE and Y (Figure 22c). In LOI-REE (or Y) diagrams, the marginal group is again clearly identified with an additional subgroup consisting of the three CR samples having a higher LOI.

There is no correlation between $\mathrm{Sr}$ or $\mathrm{O}$ isotope ratios and LOI although both isotope ratios may easily be modified by alteration and/or secondary processes. Specifically, low temperature reequilibration of the rocks with meteoric water would result in higher $\delta^{18} \mathrm{O}$ because of very positive rock/water fractionations, becoming even more positive with decreasing temperature (e.g., Zhao and Zheng, 2003).

Thus, based on the low LOI and because alteration cannot similarly affect highly mobile and immobile elements while leaving $\mathrm{Sr}$ and especially $\mathrm{O}$ isotopes unaffected, we conclude that it does not account for the characteristics of the marginal group of samples. Concerning the CR formation, alteration and small samples size cast doubt on the representativity of its 
geochemical signature and we will not try here to interpret it thoroughly. The intragroup positive correlation observed almost systematically among three samples of this group (Figure 22) could indeed just result from alteration processes. The same interpretation might be proposed for the positive correlation observed between $U$ and Th contents (Figure 16) whereas it is absent between $\mathrm{Ra}$ and $\mathrm{Th}$ activities (Figure 17). Also, bearing in mind the polygenic nature of the sampled CR deposit, the isotopic signature of PB7 (the most primitive measured in this study) could simply reflect a foreign origin. 

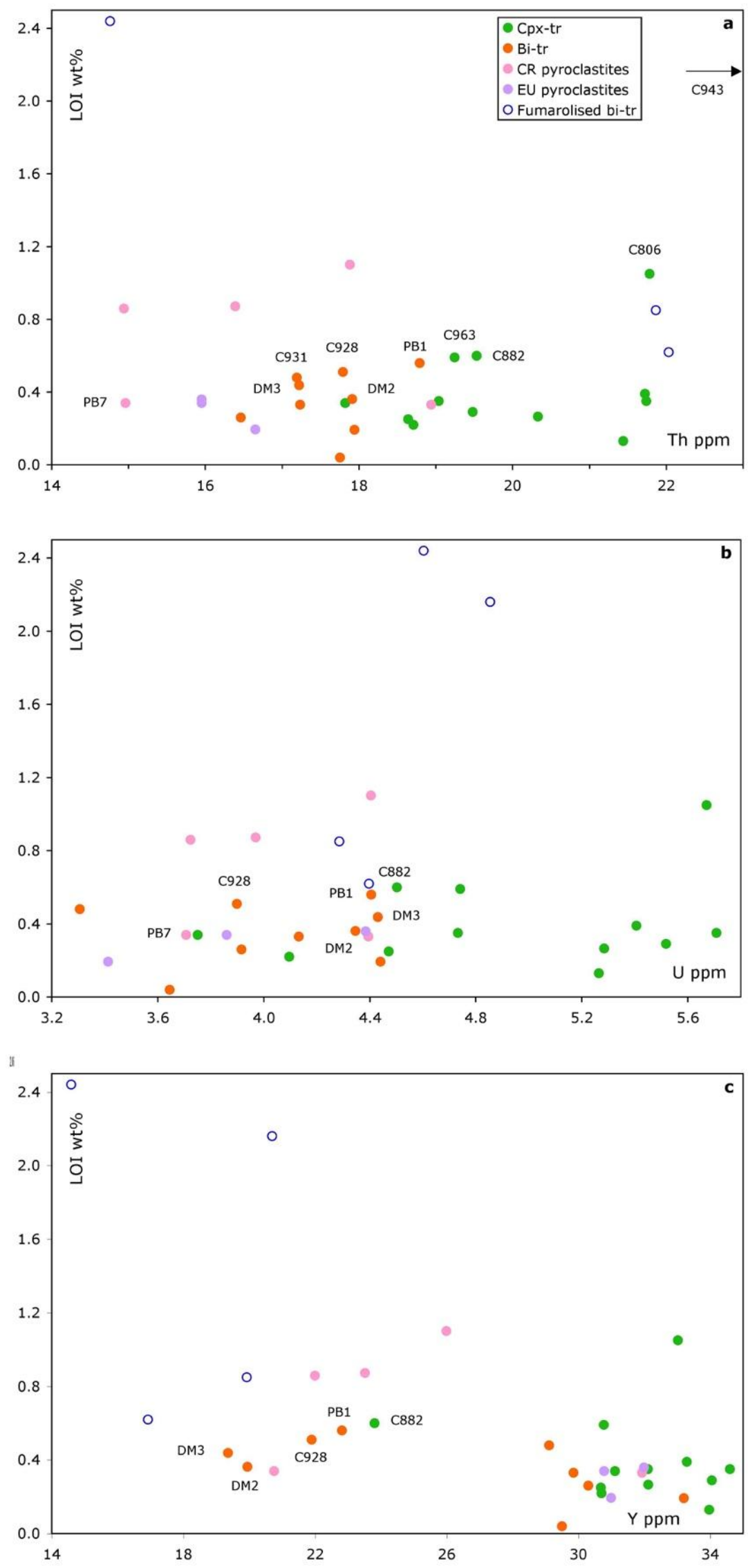

Figure 22 LOI variation 
LOI wt\% versus Th (a), U (b) and Y (c). Samples from the marginal group display low LOI and LOI displays similar correlations with either highly mobile or immobile elements, suggesting that alteration cannot account for the characteristics of this group. Three CR samples have higher LOI and a large variation is observed among fumarolised samples.

\subsubsection{Fumarolic activity}

As already noticed, fumarolic activity strongly affects the petrography, mineralogy and major element compositions (see Sections 9.4. and 11.1.1. and Supplementary Information D) of samples. A general increase in $\mathrm{TiO}_{2}$ and a decrease in $\mathrm{CaO}, \mathrm{MgO}$ and $\mathrm{K}_{2} \mathrm{O}$ are observed in Harker diagrams (Figure 14). $\mathrm{P}_{2} \mathrm{O}_{5}$ content is generally decreased whereas $\mathrm{SiO}_{2}$ content follows an opposite trend. The compositions of fumarolised samples rarely plot in the main field of fresh samples but often overlap the field of marginal samples, as best illustrated in the $\mathrm{CaO}-\mathrm{SiO}_{2}$ diagram.

Although only four fumarolised samples were analysed for trace elements, four main characteristics arise: (1) the range of concentrations is larger than for the rest of the samples, especially for the REE (Figures $15 b$ and 19a) and $\mathrm{Pb}$, (2) $\mathrm{Zr}$ and $\mathrm{Hf}$ contents are significantly higher than for all the other samples, (3) less incompatible element (Y to Lu) concentrations are lower (e.g., Figure 15b) and (4) Th concentrations are dramatically affected whereas U contents are not (Figure 16). This is consistent with the major role of late stage magmatic and hydrothermal fluids in the transport of these elements, especially the REE and Th (e.g., Bence and Taylor, 1985; Wood et al., 1997; Agangi et al., 2010; Nisbet et al., 2018; Migdisov et al., 2019). As for major elements, trace element data often plot in the field of marginal samples or toward even more extreme compositions, as well illustrated in $\mathrm{Y}-\mathrm{Nb}$ or $\mathrm{Y}$-Th diagrams (Figures 19b and 21). In the Y-Sr diagram (Figure 19c), fumarolised samples mostly correspond to the high Sr-low Y end of the low Y trend.

Based on these similarities between marginal and fumarolised samples, it is suggested that the initial compositions of the former were modified by fumarolic activity. This process cannot be fully characterised owing to the small number of analyses of fumarolised samples, and it was beyond the scope of this study. However, the complexity of this process is obvious as evidenced by (1) the large dispersion of major and trace element compositions, (2) the very large range of Th contents contrasting with essentially constant U concentrations and (3) a large Th variation at the cm-scale (as large as the variation observed among all the fresh 
samples collected on the whole volcano) which is not coupled to any obvious mineralogical differences.

The systematic depletion in HREE (including Y) and positive Eu anomalies (see Section 11.1.2.1.) characteristic of the marginal group of samples are also consistent with the LREE/HREE fractionation and differential mobility of Eu reported during hydrothermal and fumarolic alteration (e.g., Bence and Taylor, 1985; Papike et al., 1991; Migdisov et al., 2019). Cuoco et al. (2013) also reported the mobility of REE, Th and U during volcanic plume (acidic aerosols + ash)-rainwater interactions. REE and Th require low $\mathrm{pH}$ to be mobilised from ash materials whereas $\mathrm{U}$ requires higher $\mathrm{pH}$. The behaviour of these elements in the marginal group of samples would thus be compatible with interactions between acidic fumaroles and fresh trachytic material.

$\mathrm{Sr}$ and $\mathrm{Nd}$ isotope signatures of fumarolised samples do not depart from those of other samples (Figures 18a and 18b) outlining that fumarolic activity had no significant effect on both isotopic systems. This does not hold true for $\mathrm{O}$ isotopes as suggested by the two $\delta^{18} \mathrm{O}$ values (6.0 and 13.7\%) available on two fumarolised samples collected only a few $\mathrm{cm}$ apart. Interestingly, two anomalous $\delta^{18} \mathrm{O}$ signatures were also observed among the marginal group of samples, a low $\delta^{18} \mathrm{O}(5.8 \%)$ in DM3 and an exceptionally high $\delta^{18} \mathrm{O}(9.4 \%$ ) in $\mathrm{C} 882$ (Figure 20). These anomalous signatures, compatible with those of fumarolised samples, further support the hypothesis that fumarolic activity might account for the development of the geochemical signature of this marginal group. A strong decoupling between radiogenic and $\mathrm{O}$ isotopes is also clearly induced by this process. This would be consistent with the origin of the fluids involved: hydrothermal fluids with a meteoritic contribution. Indeed, late magmatic (hydrothermal) fluids probably had no isotopic contrast with the magmas while meteoric water is characterised by very low $\mathrm{Sr}$ and $\mathrm{Nd}$ contents. Only $\mathrm{O}$ is a major component in both fluids and rocks and its isotopic signature can be strongly modified during their interactions.

Besides, $\mathrm{O}$ isotopes are highly sensitive to fluid nature, relative volume and temperature (e.g., Zhao and Zheng, 2003). The coexistence of both low and high $\delta^{18} \mathrm{O}$ observed may reflect contrasting (1) temperatures of the fluids involved, which may occur as samples were collected close to a fissure through which, successively, both high and low temperature fluids may have percolated and/or (2) fluid/rock ratios.

The abundance of fumaroles in the central part of the dome was testified by numerous field observations, and especially the highly transformed character of most CR trachytes from the late summit eruption. Their role is confirmed by geochemical data. This is also consistent 
with geophysical data indicating that the dome core is significantly altered (Portal et al., 2019). Finally, fumarolic activity accounts fairly well for the development of a specific geochemical signature among samples belonging to the various trachytic groups and devoid (except CR samples) of any obvious petrological and mineralogical alteration of their pristine signature.

\subsection{A model for the edification of PdD volcano}

\subsubsection{Magma chamber and conduit processes}

The magma chamber where most of the final differentiation occurred was filled by an already evolved magma, a basaltic trachy-andesite, as documented by scarce mafic enclaves in the bitrachyte. In this model, this magma is believed to be the parent magma of PdD trachytes (Arnaud et al., 1992), and 50-70\% crystallisation would have been required to reach a bitrachytic composition. Estimating a total volume of $0.2 \mathrm{~km}^{3}$ for the edifice (see Section 3.), the magma chamber would have reached a minimum volume of $0.4-0.7 \mathrm{~km}^{3}$, which could of course have been much larger. The pre-eruptive P estimated at $350 \mathrm{MPa}$ (Martel et al., 2013) would locate this magma chamber in the felsic lower crust (Zeyen et al., 1997).

Differentiation resulted in a zoned reservoir. First, the developing trachytic part was affected by differential movements (convective self-mixing) in the magma chamber, generating localised small $\mathrm{P}_{\mathrm{H} 2 \mathrm{O}}$ ( \pm temperature) variations, as suggested by the ubiquitous occurrence of cloudy plagioclase (see Section 10.1.2. and Supplementary Information F). This process ended when the cpx-trachyte started to accumulate at the top of the reservoir. In this layer, the evolving liquid composition caused the disequilibrium of previously crystallised plagioclase phenocrysts and triggered the appearance of cpx and K-feldspar, the latter rimming preexisting plagioclase phenocrysts or occurring as individual phenocrysts. No evidence was found in favour of the destabilisation of the magma chamber by the input of a more mafic magma. In particular, plagioclase crystals (or cores) in the trachytes never exhibit the same compositions as those of the basaltic-trachyandesite enclaves. Further, the ubiquitous and recurrent development of sieve-textured plagioclase crystals, with their specific compositional zonation (see Section 10.1.2), is incompatible with a chemical variation of the system related to magma chamber replenishment. The trigger of the eruption was thus probably only related to closed-system magma evolution in this stable and zoned reservoir which eventually led to 
volatile saturation, in agreement with the pre-eruptive $\mathrm{H}_{2} \mathrm{O}$ content of $8 \mathrm{wt} \%$ experimentally estimated by Martel et al. (2013).

The conduit opened through the upper crust along the NNE-SSW fracture system of the central and northern parts of the CdP (Boivin et al., 2017). The cpx-trachyte was the first magma to ascend indicating that the magma chamber started to empty by its summit. This is consistent with the vertical stratification of the magma chamber described above, with a "mushy" bottom consisting of some 50\% cumulates overlain by the bi-trachytic and then cpxtrachytic magmas. Because of the accumulation of the more evolved magmas and associated fluids in the upper part of the reservoir, cpx-trachytic magmas were the most mobilisable and thus the first to erupt. Banding features observed in some cpx-trachytes (Figure 8) are reminiscent of the streaky features formed by mixing during magma flow in volcanic conduits (e.g., Blake and Campbell, 1986). Such mixing processes resulted in mineralogical disequilibria accompanied by isotopic variations due to the interaction between magmatic fluids and granitic country-rocks along the conduit walls. Although magmas were initially very similar, the heterogeneous degassing in the conduit and microlith crystallisation, as a function of decompression and degassing (e.g., Sparks 1997; Sparks et al., 2000), probably resulted in heterogeneous viscosity, favouring the preservation of these disequilibrium features. The oriented trachytic texture of some samples also illustrates the presence of some residual liquid at that stage.

\subsubsection{Eruption}



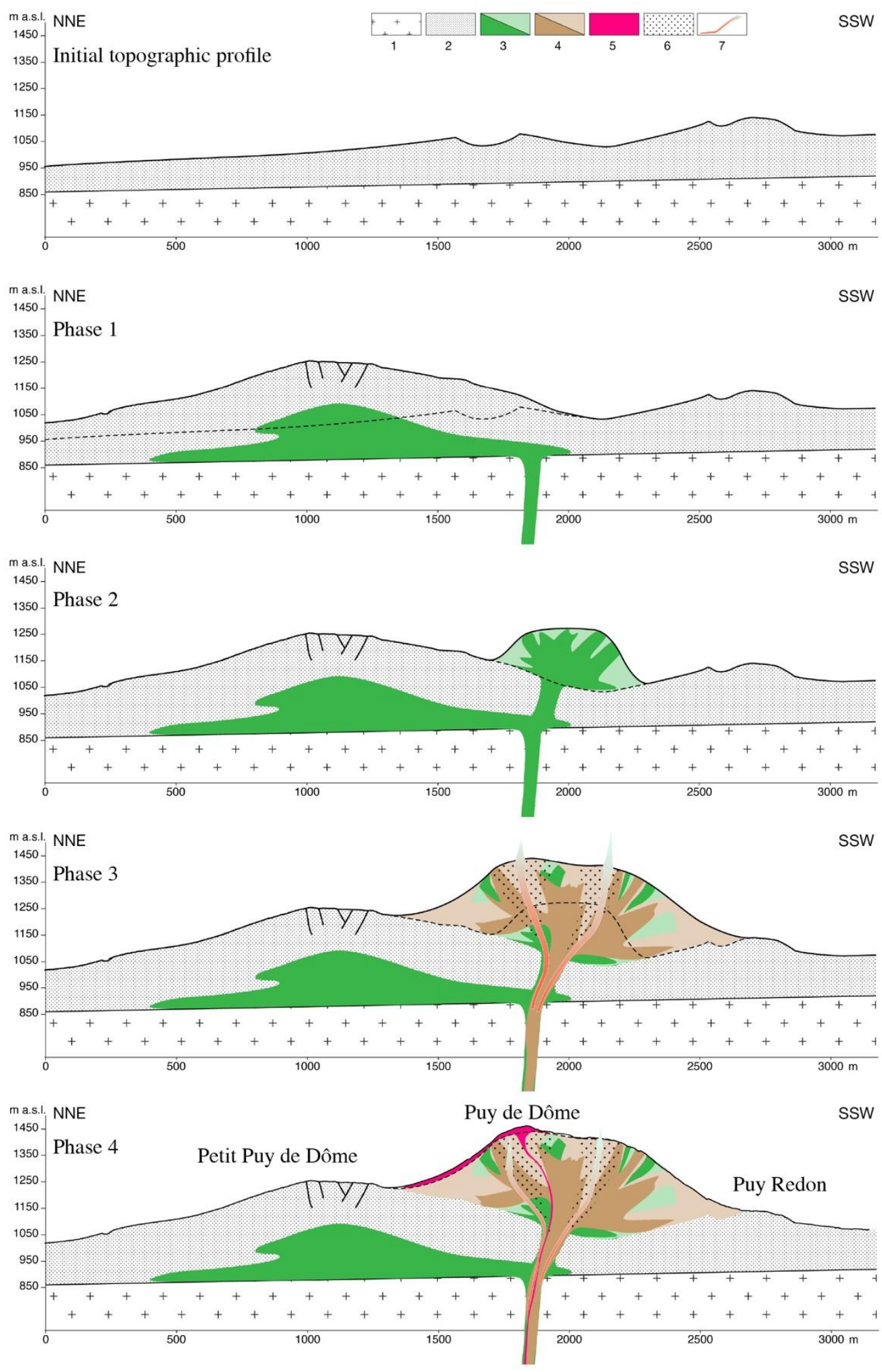

Figure 23 Four-step scenario of PdD eruption

NNE-SSW sections illustrating the four-phase eruption. Elevation is given in meters above sea level (m a.s.1.). 1: Granito-gneissic basement, 2: older volcanic formations (lava flows and 
cinder cones), 3: cpx-trachyte and associated BAF (light colour), 4: bi-trachyte and associated BAF (light colour), 5: terminal pyroclastite (EU), 6: fumarolised and silicified zones, 7: fumaroles. Phase 1: cpx-trachyte intruded and reached a mechanical discontinuity, forming a cryptodome below Petit Puy de Dôme. Phase 2: following changes in the local stress field, cpx-trachyte followed a new ascent path and reached the surface to build the dome. Phase 3: the bi-trachytic magma making the main volume of the magma chamber then reached the surface through the same conduit, penetrating the first dome as successive intrusions and breaking it up, embedding the resulting fragments. Fumarolised zones developed along fractures. Phase 4: toward the end of the bi-trachyte eruption, an explosive event occurred east of the summit producing the small volume EU deposits. Fluids still released from the dome fed fumaroles around the summit.

Based on our data, a four-step scenario is proposed for the eruption of the PdD (Figure 23).

Step 1. Close to the surface, the first ascending cpx-trachytic magmas reached a mechanical discontinuity between the granitic basement and the older volcanic units, favouring their lateral propagation and emplacement as a cryptodome (van Wyk de Vries et al., 2014). The resulting surface relief is highly fractured and corresponds to the Petit Puy de Dôme. We argue that this intrusion was later sampled by the eruption of the Nid de la Poule maar, producing cpx-trachytic deposits (see Sections 5. and 9.2.). In addition of a mechanical discontinuity and the presence of a free surface allowing space accomodation, such lateral propagation implies that the magma was sufficiently viscous and intruded at a slow enough rate to accumulate instead of flowing out and erupting (van Wyk de Vries et al., 2014).

Step 2. Following changes in the local stress field related to Petit Puy de Dôme elevation, the system was blocked. The cpx-trachytic magma followed a new ascent path right under the PdD chimney and reached the surface to build a dome made of dykes and massive intrusions mantled by mainly gravitational BAF deposits. Combined with the absence of field evidence for associated pyroclastic deposits at the periphery of the dome, this suggests an almost purely effusive activity at that stage. The lack of near-surface explosive activity implies that the exsolved gas were lost during magma ascent: gas ascending faster than the magma in the conduit must have significantly exsolved there. The gas and heat evacuated slowly in the conduit walls (systematic absence of skeletal microliths) would have favoured the wall-rock interactions inferred from geochemical data on cpx-trachytes (see Section 12.1.).

Step 3. The bi-trachytic magma making the main volume of the magma chamber then reached the surface through the same conduit. It penetrated the first cpx-trachytic dome as successive 
internal intrusions, breaking through it and breaking it up, and packing the resulting fragments (of various size) in the continuously growing main dome. Simultaneously, the outer, unstable parts of the dome reaching disequilibrium collapsed, generating BAF deposits (C-PDCs of Boudon et al., 2015) which accumulated at the periphery of the edifice. Indeed, the cpxtrachyte facies is randomly distributed at the surface of the bi-trachyte dome (Figure 7), except (i) in the SW, where it may correspond to a significant portion of the initial dome which would have been more or less preserved, and probably (ii) in the SE, where it is covered by the EU. This is supported by the abundance of cpx-trachyte blocks in the BAF deposits exposed in the old quarry at the $\mathrm{S}$ base of the PdD. All our field observations suggest that the first dome was consolidated at that stage. The final degassing-crystallisation occurred very rapidly at the base of the dome and was probably enhanced by the high porosity (see Supplementary Information C) of the trachytic material and the presence of fractures and associated fumarolised zones documented by both field and geophysical data (Portal et al., 2019). Only few explosions occurred, as attested by the presence of rare bomb sags and cross bedding in some pyroclastites interstratified in the BAF deposits. Another evidence for restricted explosivity of PdD until step 4 is the absence of tephra over some $50 \mathrm{~km}$ to the E, $\mathrm{NE}$ and $\mathrm{S}$ of the volcano, despite extensive search through numerous soundings and corings (Gérard Vernet, archeologist, personal communication $8^{\text {th }}$ February 2019). Fluids still released from the dome fed fumaroles whose past location around the summit, evidenced by field data, probably delineate the vent shape. Both the nature of the eruptive products and the almost absence of glass in the trachytes (Boudon et al., 2015 and this work) argue for almost complete degassing in the magmatic conduit and at the base of the dome.

Step 4. Toward the end of the bi-trachyte eruption, an explosive event occurred east of the summit as indicated by the massive ash deposits (EU) which cover the eastern flank of the volcano. Based on the least evolved bi-trachytic composition of these ashes, this final eruptive stage is interpreted to reflect the emptying of the mobilisable part of the bottom of the magma chamber. Because of its subordinate volume contribution to the edifice and its unusual characteristics deserving a specifically dedicated work (in progress), this unit is not further discussed in the present paper.

\subsubsection{Post-PdD eruption events}

After the PdD eruption $(11.0 \pm 0.2 \mathrm{ka})$, fumarolic activity persisted, probably involving groundwaters and PdD hydrothermal system as suggested by geophysical data (Portal et al., 
2019). Then, after at most six centuries $(10.70 \pm 0.15 \mathrm{ka})$, the edifice was mantled by the summit, late thin phreatic eruption deposits (CR formation, Miallier et al., 2010). Similar latestage phreatic eruptions are also common for dormant calc-alkaline domes with strong hydrothermal activity (e.g., La Soufrière de Guadeloupe over the last 400 years). Finally, about 9.4 ka ago, the Kilian pyroclastites (flows and falls) [Colombier et al., 2017] covered $\mathrm{PdD}$. Although beyond the scope of our study, these two last events are worth to mention as they both disturbed and masked earlier PdD deposits.

\subsubsection{PdD alkaline dome versus calc-alkaline domes}

Because they are associated with hazardous phenomena, dome-building eruptions have become a subject of growing interest in volcanology over the last twenty years. Numerous studies aiming at characterising the magmas and the fundamental processes controlling the formation and evolution of lava domes and their eruptive behaviour were published (see discussion below), some of them being focused on numerical modelling. These studies were mostly performed on active calc-alkaline volcanoes under monitoring, especially Soufrière Hills volcano at Montserrat, Mount St Helens and Merapi.

Pressurisation in the magma chamber promotes magma ascent and related decompression that, in turn, causes the exsolution of volatiles and results in degassing-induced crystallisation in the magma conduit (e.g., Cashman and Blundy, 2000; Sparks et al., 2000). Degassinginduced crystallisation causes material stiffening and enhances material strength reflected in non-Newtonian magma behaviour, the magma becoming a hot crystalline mush with only small amounts of residual melt (e.g., Sparks et al., 2000). This degassing-induced crystallisation process is dominant in andesitic domes such as Soufrière Hills and Merapi volcanoes (Sparks, 1997; Melnik and Sparks, 1999; Hammer et al., 2000; Innocenti et al., 2013a; 2013b), especially regarding the transition from effusive to explosive activity. Further, periods of reduced effusive flow rates promote degassing-induced crystallisation as modelled for Mount St Helens and Montserrat (Husain et al., 2014; 2018). The result is the development of a viscous plug in the upper conduit that is pushed out by a new pulse of fresh magma (Husain et al., 2018). Thus, extensive groundmass crystallisation indicative of strong gas (and heat) loss during magma ascent drastically increases magma viscosity, typically by several orders of magnitude (e.g., Sparks, 1997). This results in strong viscosity gradients, both vertical and horizontal (e.g., Sparks, 1997; Burgisser et al., 2010) across magma conduits leading to (1) large excess pressures and pressure gradients at the top of the conduit and in the 
dome (Sparks, 1997), especiallly in the case of syn-eruptive cristobalite precipitation generating an impermeable and rigid carapace at the surface of the dome (Boudon et al., 2015) and (2) a build-up of shear stress near the conduit wall where magma can behave in a brittle manner (e.g., Neuberg et al., 2006).

At first sight, the PdD alkaline dome ressembles Pelean-type lava domes (Lacroix, 1904; Calder et al., 2005) surrounded by aprons of scree, and whose morphology was strongly controlled by the presence of older surrounding volcanoes. The successive domes making the western PdD landform resemble La Soufrière dome in Guadeloupe whereas the small spines on the flanks are similar to those of Lassen Peak, California (Boivin et al., 2017). PdD mostly emplaced as relatively massive intrusions and spines accompanied by gravitational BAF, as did Soufrière Hills for example (e.g., Watts et al., 2002), but without Vulcanian flows. PdD activity was essentially effusive, contrary to that of andesitic/dacitic lava domes. Only step 4 marks a change in eruptive dynamics with an exogeneous construction by pyroclastites vented from the summit. This will be discussed in another paper.

All PdD trachytes exhibit a highly cristalline groundmass almost devoid of glass (Boudon et al., 2015 and this study) which is compatible with almost complete magma degassing during ascent, contrary to other crystal-rich calc-alkaline domes which may contain locally up to $50 \%$ of glass (e.g., Calder et al., 2005). This may be related to the initial high water content of PdD magmas favouring crystal growth (e.g., Cashman and Blundy, 2000). By comparison, dissolved water in melts at Montserrat was estimated at $4.3 \mathrm{wt} \%$ (Barclay et al., 1998) for an up to $90 \%$ crystalline lava extruded at the free surface, whereas typical water contents of andesitic melt involved in lava domes is usually 4-7 wt\% (Melnik and Sparks, 2005 and references therein).

A significant amount of gas was probably lossed through the conduit walls as inferred from the banded-features and geochemical characteristics of PB5 sample. By analogy with calcalkaline domes, these banded-features probably reflect viscosity and stress heterogenities in the conduit (e.g., Watts et al., 2002; Neuberg et al., 2006; Hale and Mülhaus, 2007). These shear-structures initiating at the junction of the conduit and the base of the dome would propagate upwards into the dome (Watts et al., 2002) and control to some degree the lava extrusion style, especially the transition from endogeneous to exogeneous growth of lava domes (e.g., Hale and Wadge, 2008). The striations parallel with the direction of flow on PdD spines and some BAF blocks, as at Montserrat and Mount St Helens (Sparks et al., 2000; Watts et al., 2002; Sherrod et al., 2008), would be indicative of such style of extrusion, controlled by shear-bands in the conduit. Further, the emplacement of PdD, essentially as 
intrusions and spines, is similar to that modelled at Montserrat for highly cristalline and viscous material intruding at low flow rates (Husain et al., 2014; 2018 and references therein). Despite a high pre-eruptive gas content, PdD magmas were thus already strongly degassed when they reached the top of the conduit and the dome interior. Furthermore, PdD trachytes are mostly chalk-like, which seems quite exceptional. PdD dome rocks with their high permeability due to pore connectivity, combined with the large-scale fracture permeability of the edifice and fumaroles probably account for the non explosivity of the dome itself. Degassing predominantly through fumaroles around dome margins was also reported at Lascar and Galeras (Matthews et al., 1997; Stix et al.,1997).

Summarising, the specificities of the PdD compared to andesitic domes are (i) the absence of lava flow, apparently related to the high $\mathrm{SiO}_{2}$ content and high viscosity of the magmas (Boivin and Thouret, 2013), (ii) the varied nature of magmas and (iii) the extreme porosity of most trachytes and extensive groundmass crystallisation in all the samples, compatible with almost complete magma degassing during ascent, and accounting for the absence of significant explosive activity until step 4 eruption. $\mathrm{PdD}$ would thus be an equivalent of the effusive stage of Montserrat, more specifically, that corresponding to low flow rates.

Also, albeit very similar in geochemical compositions (e.g., Boivin et al., 2017) and preeruptive conditions (Martel et al., 2013), the spatially very close trachytic domes of the CdP display very distinct eruptive histories (Boivin et al., 2017). This suggests significant differences in magma ascent mechanisms and, by inference, in the processes of degassing/crystallisation in their respective magma columns. Furthermore, the significantly distinct morphologies of these trachytic edifices appear correlated with the variation of $\mathrm{SiO}_{2}$, despite its relatively restricted range of 7 wt\% (Figure S8 in Supplemenatry Information G). As yet, conduit flow models have not been linked to the surface morphology of an evolving lava dome (Husain et al., 2018 and references therein) but these data suggest that the morphology of domes may be strongly controlled by the initial rheological features of the magmas filling the magma chamber.

It is known that the variation in rheology of ascending magmas is largely controlled by degassing-induced crystallisation in the magma conduit thereby defining the effusive versus explosive eruptive behaviour (e.g., Burgisser et al., 2011). However, the transition from effusive to explosive activity at domes still remains a major issue, especially regarding hazard mitigation. Indeed, very small changes in the amount of liquid, crystals size/distribution and gas bubbles, changes in $\mathrm{P}$ and $\mathrm{T}$, as well as changes in conduit shape/size can induce drastic changes in the eruptive behavior (e.g., Melnik and Sparks, 1999; 2005). Deciphering the 
respective influence of magma chamber dynamics and magma column processes is thus a difficult task when studying calc-alkaline domes due to the complexity of these multi-stage magmatic systems. The much simpler magmatic history of monogenetic edifices, with a small magma chamber operating only once, offers an opportunity to study more easily magma column processes and thus better understand the edification of the much more complex calcalkaline domes.

\section{Conclusions}

The originality of this work resides in the fact that the eruptive scenario has been unravelled for a fossil ca. $11 \mathrm{ka}$ old dome. It is indeed usually registered step by step on active calcalkaline domes under monitoring. Although it has been known for a long time that PdD was formed by at least two distinct building phases (Camus, 1975), until now, it was considered that its magma composition was homogeneous and could be described as a single typical sample. Our detailed and multidisciplinary work allows the characterisation of the PdD magmatic system and the reconstruction of its eruptive scenario, documenting a much more complex history. Indeed, although the range of petrological and geochemical variation is restricted, differentiation among alkaline compositions provides valuable markers, such as the appearance of cpx and K-feldspar, to identify the different stages of evolution of the magma and the distinct phases of the eruption. This would be almost impossible with calc-alkaline fossil domes due to the lack of such markers in the differentiation of calc-alkaline series.

Two main lava facies, bi-trachyte and cpx-trachyte, evolved in the upper crustal zoned magma chamber initially filled by a basaltic trachy-andesite. Magma differentiation resulting in volatile saturation was the trigger of the eruption. Crystal fractionation and self-mixing processes occurred during differentiation. Then, magma-conduit walls interactions under the influence of magmatic fluids and fumarolic activity took place during magma ascent and emplacement.

The four-step eruption consists of (i) intrusion of the more evolved cpx-trachyte as a cryptodome, (ii) edification of the first cpx-trachyte dome by successive intrusions, (iii) edification of the main bi-trachyte dome by successive intrusions breaking through the first dome and breaking it up, embedding the resulting blocks in the continuously growing main dome, (iv) explosive summit activity, corresponding to the eruption of the less differentiated magmas, which resulted in strong ash emission which covered the eastern flank of PdD. 
PdD activity was thus mostly effusive, suggesting that magmas were strongly degassed during ascent, as also indicated by extensive groundmass crystallisation in all the samples (almost no glass). Degassing occurred in the magmatic conduit by degassing-induced crystallisation, resulting in a significant increase of magma viscosity, as reflected by the extrusion style (intrusions and spines). Gas escape occurred in the conduit as attested in the cpx-trachyte facies, and probably ended at the base of the dome. The highly porous nature of the trachyte and the presence of fractures and associated fumarolised zones must have favoured gas escape, preventing any autoexplosivity of the dome itself.

These results offer an insight into the dynamics of magma chamber and conduit processes associated to alkaline domes as well as their eruptive conditions. They document strong similarities with those encountered at calc-alkaline domes, indicating that the simpler magmatic systems of the former may help understanding the much more complex ones of the latter. The specificities of PdD compared to calc-alkaline domes are the absence of lava flow, the varied nature of magmas, the mostly highly porous nature of its trachytes and its very limited explosive activity. By analogy, PdD activity would mostly correspond to the lower flow rate effusive stage of Montserrat, also characterised by the development of intrusions and spines.

\section{Acknowledgements}

T. Pilleyre, M.C. Sforna and A. Gourgaud are thanked for their contribution to sampling; C. Constantin, C. Bosq, D. Auclair, N. Cluzel, J.L. Devidal, J.M. Hénot and M. Benbakkar for their contribution to the preparation of some samples and/or some analyses; and Société Lavallin for access to the Panoramique des Dômes work site. The SARM (CRPG, Nancy) produced all the major and trace elements for the main set of samples. Radiocarbone analyses were performed by the National Platform LMC14 (LSCE (CNRS - CEA - UVSQ) - IRD IRSN - MC), with the financial support of INSU. The LIDAR data used in this study derive from a collective project financially supported by the Conseil Départemental du Puy de Dôme (CD63), the European Regional Development Fund (FEDER) and the University of Clermont-Ferrand. It was scientifically validated by P. Labazuy et al. (2012). We are also grateful to D. Briot, J.C. Thouret and, especially, L. Arbaret and C. Pin for fruitful discussions and valuable comments and suggestions on the successive versions of the manuscript which greatly helped to improve this paper. Reviews by K. Nemeth and an anonymous reviewer led 
to substantial improvement of the manuscript. We are grateful to J.L. Macías Vázquez for edits/comments and for handling the manuscript. This research was partly supported by the French Government Laboratory of Excellence initiative $n^{\circ}$ ANR-10-LABX-0006, the Région Auvergne and the European Regional Development Fund. This is Laboratory of Excellence ClerVolc contribution number 339.

\begin{tabular}{|c|c|c|c|c|c|c|c|c|}
\hline Index & Short reference & Lab. reference & $\mathrm{x}$ & $\mathrm{Y}$ & Geological unit & Nature of the sample & Petrographic facies & Magmatic facies \\
\hline 1 & 1103-02 & PB11-1103-02 & 497116 & 5068574 & Core of the dome, at the summit & Massive dome lava & $\mathrm{K}$-oligoclase, sanidine, biotite and $\mathrm{cpx}$ trachyte & Cpx-trachyte \\
\hline 2 & $1105-2$ & PB15-1105-2 & 497369 & 5068606 & Pyroclastites of the eastern unit & Block of massive dome lava $(>0.2 \mathrm{~m})$ & K-oligoclase and biotite trachyte & Bi-trachyte \\
\hline 3 & C511 & C511 & 496916 & 5068829 & CR pyroclas tites (summit of the dome) & $\mathrm{cm}$-sized lapilli & K-oligoclase and biotite trachyte & Bi-trachyte \\
\hline 4 & C511a & C511a & 496916 & 5068829 & CR pyroclas tites (summit of the dome) & cm-sized lapilif & $\mathrm{K}$-oligoclase and biotite trachyte & Bi-trachyte \\
\hline 5 & $\mathrm{C} 663$ & C663 & 497008 & 5068801 & CR pyroclastites (summit of the dome) & cm-sized lapili & K-oligoclase and biotite trachyte & Bi-trachyte \\
\hline 6 & C806 & C806 & 498018 & 5068041 & BAF deposit, $\mathrm{S}$ base of the dome & Block of massive dome lava $(-0.2 \mathrm{~m})$ & $\mathrm{K}$-oligoclase, sanidine, biotte and $\mathrm{cpx}$ trachyte & Cpx-trachyte \\
\hline 7 & C882 & C882 & 497440 & 5068906 & Ridge, NE of the dome & Massive dome lava & $\mathrm{K}$-oligoclase, sanidine, biotite and $\mathrm{cpx}$ trachyte & Cpx-trachyte \\
\hline 8 & C915 & C915 & 496814 & 5068653 & Ridge, $W$ of the dome & Massive dome lava & $\mathrm{K}$-oligoclase, sanidine, biotite and $\mathrm{cpx}$ trachyte & Cpx-trachyte \\
\hline 9 & C928 & C928 & 496766 & 5068753 & Ridge, $W$ of the dome & Massive dome lava & $\mathrm{K}$-oligoclase and biotite trachyte & Bi-trachyte \\
\hline 10 & C931 & C931 & 496792 & 5068685 & Ridge, $W$ of the dome & Massive dome lava & K-oligoclase and biotite trachyte & Bi-trachyte \\
\hline 11 & C943 & C 943 & 496865 & 5068569 & Upper western rim of the dome & Hydrothermalised/fumarolised massive dome lava & K-oligoclase and biotite trachyte. Red colored & Bi-trachyte \\
\hline 12 & C949 & C949 & 497258 & 5068310 & Pyroclastites of the eastern unit & Tuff & K-oligoclase and biotite trachyte & Bi-trachyte \\
\hline 13 & C950 & C950 & 497747 & 5068366 & Pyroclastites of the eastern unit & Tuff & K-oligoclase and biotite trachyte & Bi-trachyte \\
\hline 14 & c951 & C951 & 498018 & 5068041 & BAF deposit, $S$ base of the dome & Block of massive dome lava $(\sim 1 \mathrm{~m})$ & K-oligoclase, sanidine, biotite and cpx trachyte & Cpx-trachyte \\
\hline 15 & C963 & C963 & 497258 & 5068310 & BAF deposit, $\mathrm{S}$ flank of the dome & Block of massive dome lava $(\sim 2.5 \mathrm{~m})$ & $\mathrm{K}$-oligoclase, sanidine, biotite and $\mathrm{cpx}$ trachyte & Cpx-trachyte \\
\hline 16 & DM1 & C724/DM1 & 497258 & 5068310 & Pyroclastites of the eastern unit & Tuff & $\mathrm{K}$-oligoclase and biotite trachyte & Bi-trachyte \\
\hline 17 & DM2 & C726/DM2 & 497408 & 5068701 & Pyroclastites of the eastern unit & Block of massive dome lava $(-1.2 \mathrm{~m})$ & $K$-oligoclase and biotite trachyte & Bi-trachyte \\
\hline 18 & DM3 & C727/DM3 & 497408 & 5068701 & Pyroclastites of the eastern unit & Block of massive dome lava $(\sim 0.8 \mathrm{~m})$ & K-oligoclase and biotite trachyte & Bi-trachyte \\
\hline 19 & DM4 & C728/DM4 & 497448 & 5068905 & Ridge, NE of the dome & Massive dome lava & K-oligoclase, sanidine, biotite and $\mathrm{cpx}$ trachyte & Cpx-trachyte \\
\hline 20 & DM5 & C730/DM5 & 496643 & 5068938 & CR pyroclastites ( $W$ flank of the dome) & Block $(\sim 0.3 \mathrm{~m})$ & $\mathrm{K}$-oligoclase and biotite trachyte & Bi-trachyte \\
\hline 21 & DM6 & C731/DM6 & 497297 & 5068573 & Pyroclastites of the eastern unit & Block of massive dome lava ( $>1 \mathrm{~m}$ ) & K-oligoclase and biotite trachyte & Bi-trachyte \\
\hline 22 & PB1 & PB08-2901-1/PDD 1/PB1 & 497046 & 5068501 & Spine, $S$ of the dome & Massive dome lava & $K$-oligoclase and biotite trachyte & Bi-trachyte \\
\hline 23 & PB15-1210-1 & PB15-1210-1 & 497254 & 5068560 & Pyroclastites of the eastern unit & Hydrothermalised/fumarolised tuff & K-oligoclase and biotite trachyte. White colored & Bi-trachyte \\
\hline 24 & PB15-1210-2 & PB15-1210-2 & 497254 & 5068560 & Pyroclastites of the eastern unit & Hydrothermalised/fumarolised tuff & K-oligoclase and biotite trachyte. Yellow colored & Bi-trachyte \\
\hline 25 & PB15-1210-3 & PB15-1210-3 & 497254 & 5068560 & Pyroclastites of the eastern unit & Hydrothermalised/fumarolised tuff & K-oligoclase and biotte trachyte. Pink colored & Bi-trachyte \\
\hline 26 & PB2 & PB08-2901-2/PDD2/PB2 & 497371 & 5068772 & Spine, E of the dome & Massive dome lava & K-oligoclase and biotite trachyte & Bi-trachyte \\
\hline 27 & PB3 & PB08-2901-3/PDD3/PB3 & 496895 & 5068951 & Ridge, $W$ of the dome & Massive dome lava & K-oligoclase, sanidine, biotite and cpx trachyte & Cpx-trachyte \\
\hline 28 & P84 & PB08-2901-4/PDD4/PB4 & 496851 & 5068905 & Spine, $W$ of the dome & Massive dome lava & K-oligoclase and biotite trachyte & Bi-trachyte \\
\hline \multirow[t]{3}{*}{29} & P85 & PB08-2801-1/PDD5/PB5 & 497920 & 5069045 & BAF deposit $E$ base of the dome & Block of massive dome lava $(>3 \mathrm{~m}$ ) & $\mathrm{K}$-oligoclase, sanidine, biotite and $\mathrm{cpx}$ trachyte & Cpx-trachyte \\
\hline & PB5C & & 497920 & 5069045 & & Light colored facies of the sample & & \\
\hline & PB5F & & 497920 & 5069045 & & Dark colored facies of the sample & & \\
\hline 30 & PB6 & PB08-2901-6/PDD6/PB6 & 497117 & 5069037 & NW flank, outer side of the dome & Block of massive dome lava $(>0.2 \mathrm{~m})$ & Trachyte with K-oligoclase, sanidine, biotite and cpx & Cpx-trachyte \\
\hline 31 & PB7 & C511/PB7 & 496916 & 5068829 & CR pyroclastites (summit of the dome) & cm-sized lapilif & Trachyte with K-oligoclase and biotite & Bi-trachyte \\
\hline
\end{tabular}

\section{Table 1 Samples description}

Main features of the analysed samples (main set). "Index" numbers refer to the location of samples in Figure 7 and "short reference" numbers to those used in the text. Orange and green colours refer to bi-trachytes and cpx-trachytes, respectively. Colours in the "short reference" column refer to the magmatic groups identified in the geochemical diagrams. 


\begin{tabular}{|c|c|c|c|c|}
\hline Nature of phenocryst phases & \multicolumn{2}{|l|}{ Feldspar } & \multicolumn{2}{|l|}{ Biotite } \\
\hline \multicolumn{5}{|l|}{ Bi-trachyte } \\
\hline \multirow[t]{2}{*}{ Number of measured crystals } & \multicolumn{2}{|l|}{493} & \multicolumn{2}{|l|}{599} \\
\hline & $\%$ (surface) & Size $\max (\mathrm{mm})$ & $\%$ (surface) & Size $\max (\mathrm{mm})$ \\
\hline Mean & 9.1 & 6.0 & 1.5 & 2.6 \\
\hline std dev & 3.5 & 1.3 & 0.5 & 0.6 \\
\hline Min & 2.1 & 3.4 & 0.7 & 1.5 \\
\hline Max & 14.6 & 7.9 & 2.4 & 3.6 \\
\hline \multicolumn{5}{|l|}{ Cpx-trachyte } \\
\hline \multirow[t]{2}{*}{ Number of measured crystals } & \multicolumn{2}{|l|}{723} & \multicolumn{2}{|l|}{692} \\
\hline & $\%$ (surface) & Size $\max (\mathrm{mm})$ & $\%$ (surface) & Size $\max (\mathrm{mm})$ \\
\hline Mean & 11.5 & 6.0 & 1.4 & 2.2 \\
\hline std dev & 3.9 & 1.5 & 0.5 & 0.8 \\
\hline Min & 5.3 & 4.1 & 0.8 & 1.2 \\
\hline Max & 19.8 & 16.0 & 2.5 & 3.5 \\
\hline
\end{tabular}

Table 2 Statistical assessment of the modal analyses

Comparison of the maximum size and relative abundances of phenocrysts (30 thin sections of 28 samples, 14 of each facies) in bi-trachytes and cpx-trachytes.

\begin{tabular}{|c|c|c|c|c|c|c|c|c|c|}
\hline \multirow{2}{*}{\begin{tabular}{|l} 
Mineral \\
Trachyte type
\end{tabular}} & \multicolumn{2}{|c|}{ Biotite } & \multirow{2}{*}{\begin{tabular}{|c|} 
Clinopyroxene \\
Cpx-Trachyte
\end{tabular}} & \multicolumn{2}{|c|}{ Feldspar phenocrysts } & \multicolumn{2}{|c|}{ Feldspar microliths } & \multicolumn{2}{|c|}{ Cristobalite } \\
\hline & Bi-trachyte & Cpx-Trachyte & & Bi-trachyte & Cpx-Trachyte & Bi-trachyte & Cpx-Trachyte & main & secondary \\
\hline Number & 133 & 72 & 51 & 170 & 100 & 126 & 18 & 94 & 15 \\
\hline $\mathrm{SiO}_{2}$ & $35.85(0.56)$ & $35.72(0.43)$ & $51.80(0.45)$ & $62.14(2.43)$ & $64.35(1.83)$ & $65.55(1.30)$ & $66.47(0.89)$ & $97.57(97.59)$ & $94.49(95.49)$ \\
\hline $\mathrm{TiO}_{2}$ & $5.49(0.23)$ & $5.45(0.27)$ & $0.24(0.07)$ & - & - & - & - & $0.14(0.14)$ & $0.17(0.17)$ \\
\hline $\mathrm{Al}_{2} \mathrm{O}_{3}$ & $14.10(0.40)$ & $13.83(0.41)$ & $1.34(0.30)$ & $23.24(1.64)$ & $21.12(1.80)$ & $20.02(1.19)$ & $19.40(1.09)$ & $1.78(1.80)$ & $3.15(2.55)$ \\
\hline $\mathrm{Fe}_{2} \mathrm{O}_{3}$ & - & - & $2.54(0.65)$ & - & - & - & - & - & - \\
\hline $\mathrm{FeO}$ & $17.05(0.92)$ & $17.51(1.05)$ & $8.83(0.66)$ & $0.31(0.13)$ & $0.27(0.13)$ & $0.49(0.12)$ & $0.48(0.17)$ & $0.09(0.09)$ & $0.20(0.16)$ \\
\hline $\mathrm{MnO}$ & $0.70(0.15)$ & $0.82(0.22)$ & $2.62(0.32)$ & - & - & - & - & $0.01(0.00)$ & $0.01(0.00)$ \\
\hline $\mathrm{MgO}$ & $12.62(0.56)$ & $12.26(0.71)$ & $11.08(0.40)$ & - & - & - & - & $0.00(0.00)$ & $0.01(0.00)$ \\
\hline $\mathrm{CaO}$ & - & - & $20.49(0.35)$ & $4.83(1.91)$ & $2.64(1.88)$ & $1.57(1.04)$ & $0.96(0.80)$ & $0.03(0.02)$ & $0.04(0.04)$ \\
\hline $\mathrm{Na}_{2} \mathrm{O}$ & $0.74(0.14)$ & $0.70(0.13)$ & $1.00(0.10)$ & $7.76(0.79)$ & $7.28(1.26)$ & $7.24(0.78)$ & $6.95(0.62)$ & $0.69(0.71)$ & $0.91(0.87)$ \\
\hline $\mathrm{K}_{2} \mathrm{O}$ & $8.79(0.30)$ & $8.87(0.28)$ & - & $1.42(0.56)$ & $3.95(3.19)$ & $4.82(1.87)$ & $5.72(1.38)$ & $0.05(0.03)$ & $0.65(0.48)$ \\
\hline Total & 95.34 & 95.16 & 99.94 & 99.71 & 99.61 & 99.68 & 99.98 & 100.37 & 99.63 \\
\hline $\begin{array}{l}\text { Number of O } \\
\text { atoms per } \\
\text { formula unit }\end{array}$ & 22 & 22 & 6 & 32 & 32 & 32 & 32 & & \\
\hline $\mathrm{Si}$ & $5.442(0.047)$ & $5.455(0.048)$ & $1.964(0.013)$ & $11.086(0.384)$ & $11.522(0.357)$ & $11.733(0.227)$ & $11.875(0.183)$ & & \\
\hline $\mathrm{Ti}$ & $0.627(0.026)$ & $0.626(0.029)$ & $0.007(0.002)$ & - & - & - & - & & \\
\hline $\mathrm{Al}$ & $2.523(0.061)$ & $2.490(0.065)$ & $0.060(0.013)$ & $4.890(0.369)$ & $4.455(0.363)$ & $4.222(0.245)$ & $4.084(0.209)$ & & \\
\hline $\mathrm{Fe}^{3+}$ & - & - & $0.073(0.019)$ & - & - & - & - & & \\
\hline $\mathrm{Fe}^{2+}$ & $2.165(0.125)$ & $2.237(0.146)$ & $0.280(0.021)$ & $0.046(0.020)$ & $0.041(0.019)$ & $0.073(0.018)$ & $0.071(0.026)$ & & \\
\hline $\mathrm{Mn}$ & $0.090(0.020)$ & $0.106(0.029)$ & $0.084(0.010)$ & - & - & - & - & & \\
\hline $\mathrm{Mg}$ & $2.856(0.111)$ & $2.789(0.146)$ & $0.626(0.021)$ & - & - & - & - & & \\
\hline $\mathrm{Ca}$ & - & - & $0.832(0.012)$ & $0.926(0.373)$ & $0.506(0.360)$ & $0.300(0.200)$ & $0.183(0.151)$ & & \\
\hline $\mathrm{Na}$ & $0.217(0.040)$ & $0.207(0.037)$ & $0.074(0.008)$ & $2.683(0.264)$ & $2.524(0.422)$ & $2.511(0.264)$ & $2.405(0.200)$ & & \\
\hline K & $1.702(0.057)$ & $1.728(0.057)$ & - & $0.323(0.127)$ & $0.905(0.738)$ & $1.101(0.431)$ & $1.306(0.319)$ & & \\
\hline Total & 15.624 & 15.638 & 3.999 & 19.954 & 19.952 & 19.940 & 19.924 & & \\
\hline mg* & - & - & $69.12(2.16)$ & - & - & - & - & & \\
\hline$[\mathrm{Mg}]$ & $56.887(2.241)$ & $55.489(2.811)$ & - & - & - & - & - & & \\
\hline $\mathrm{Si} / \mathrm{Al}$ & $2.158(0.065)$ & $2.193(0.073)$ & - & - & - & - & - & & \\
\hline An & - & - & - & $24.43(9.48)$ & $13.43(9.57)$ & $8.00(5.36)$ & $4.90(4.02)$ & & \\
\hline $\mathrm{Ab}$ & - & - & - & $66.98(6.91)$ & $62.87(11.01)$ & $62.83(6.71)$ & $60.36(5.01)$ & & \\
\hline Or & - & - & - & $8.59(3.43)$ & $23.71(19.06)$ & $29.16(11.23)$ & $34.76(8.45)$ & & \\
\hline
\end{tabular}

Table 3 Microprobe and Raman mean compositions of the minerals (wt\% and atoms). 
Mean compositions (and associated standard errors) of the main minerals in the bi-trachyte and cpx-trachyte. 


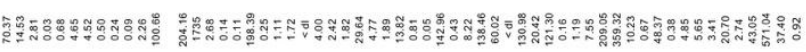

รัง

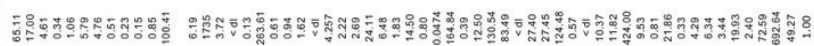

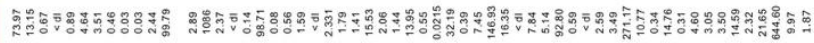

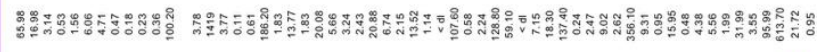

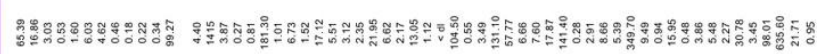

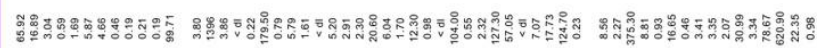

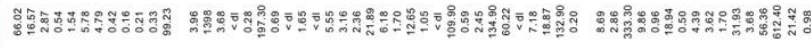

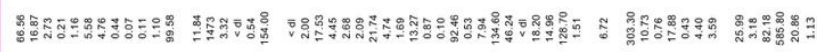

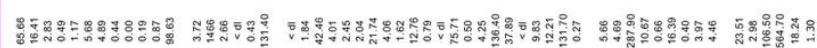

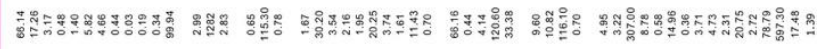





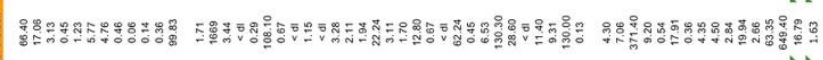

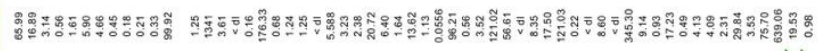

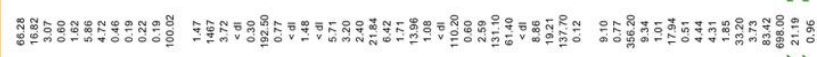

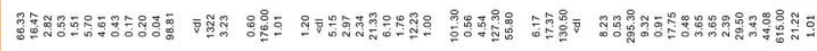

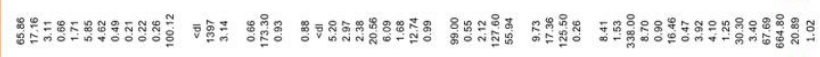

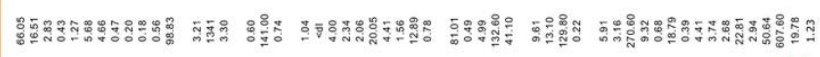

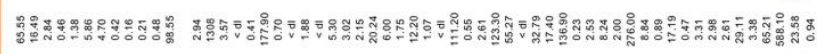

ว

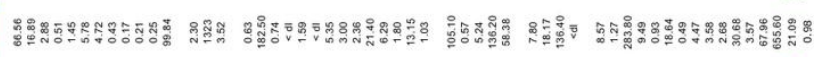

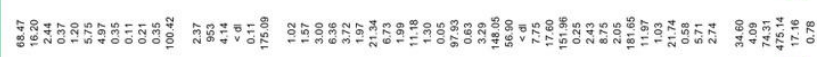

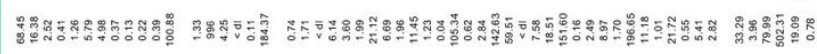

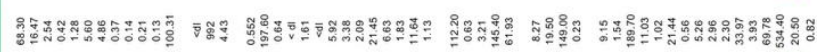



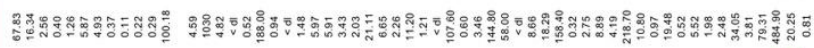

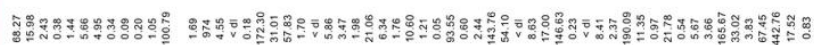

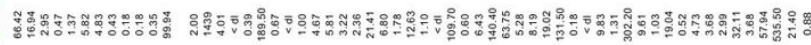

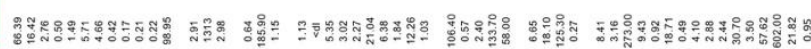

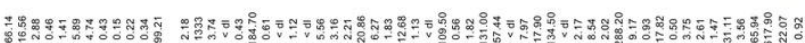

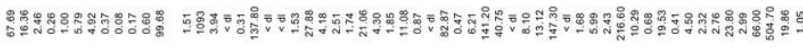

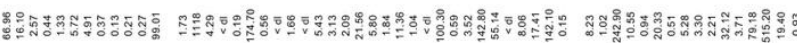

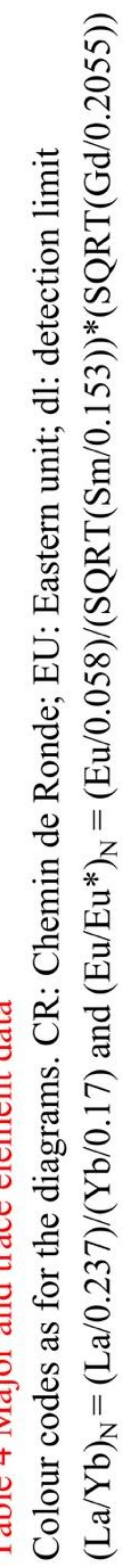

ไทำ 


\begin{tabular}{|c|c|c|c|c|c|c|c|}
\hline Sample & Unit & ${ }^{87} \mathrm{Sr} /{ }^{86} \mathrm{Sr}$ & 2SE abs & ${ }^{143} \mathrm{Nd} /{ }^{144} \mathrm{Nd}$ & 2SE abs & $\delta^{18} \mathrm{O}_{\mathrm{WR}} \%$ & \\
\hline DM4 & Cpx-tr massive & 0.704549 & 7 & & & & \\
\hline C882 & Cpx-tr massive & 0.704570 & 7 & 0.512735 & 7 & 9.35 & \\
\hline PB3 & Cpx-tr massive & 0.704498 & 7 & 0.512741 & 7 & & \\
\hline PB5 & Cpx-tr blocks & 0.704558 & 6 & 0.512744 & 7 & & \\
\hline \multirow[t]{3}{*}{ PB5C } & Cpx-tr blocks & 0.704567 & mean 2 & 0.512738 & 3 & 7.24 & \\
\hline & & 0.704564 & 6 & & & & \\
\hline & & 0.704571 & 8 & & & & \\
\hline \multirow{3}{*}{ PB5F } & Cpx-tr blocks & 0.704637 & mean 2 & 0.512732 & 3 & 7.45 & \\
\hline & & 0.704636 & 8 & & & & \\
\hline & & 0.704639 & 6 & & & & \\
\hline \multirow[t]{5}{*}{ PB6 } & Cpx-tr blocks & 0.704523 & mean 4 & 0.512745 & 7 & 7.46 & \\
\hline & & 0.704520 & 5 & & & & \\
\hline & & 0.704525 & 8 & & & & \\
\hline & & 0.704522 & 8 & & & & \\
\hline & & 0.704526 & 10 & & & & \\
\hline C928 & Bi-tr massive & 0.704505 & 7 & 0.512740 & 4 & 6.85 & \\
\hline C931 & Bi-tr massive & 0.704515 & 8 & & & & \\
\hline PB1 & Bi-tr massive & 0.704503 & 6 & 0.512739 & 7 & 6.57 & \\
\hline PB2 & Bi-tr massive & 0.704497 & 5 & 0.512744 & 3 & 6.48 & \\
\hline PB4 & Bi-tr massive & 0.704503 & 5 & 0.512737 & 5 & & \\
\hline DM3 & Bi-tr blocks & 0.704491 & 7 & 0.512734 & 5 & 5.73 & \\
\hline PB7 & CR pyroclastites & 0.704463 & 5 & 0.512796 & 7 & & \\
\hline DM5 & CR pyroclastites & 0.704492 & 5 & & & & \\
\hline C949 & EU pyroclastites & 0.704492 & 7 & & & & \\
\hline \multirow[t]{3}{*}{ C950 } & EU pyroclastites & 0.704496 & 7 & & & 7.40 & mean 2 \\
\hline & & & & & & 7.39 & \\
\hline & & & & & & 7.41 & \\
\hline \multirow[t]{3}{*}{ PB15-1210-1 } & Fumarolised Bi-tr & 0.704499 & 7 & 0.512737 & 3 & 13.68 & mean 2 \\
\hline & & & & & & 13.75 & \\
\hline & & & & & & 13.60 & \\
\hline \multirow[t]{3}{*}{ PB15-1210-2 } & Fumarolised Bi-tr & 0.704518 & mean 2 & 0.512737 & 4 & 5.98 & \\
\hline & & 0.704520 & 9 & & & & \\
\hline & & 0.704513 & 5 & & & & \\
\hline PB15-1210-3 & Fumarolised Bi-tr & 0.704486 & 7 & & & & \\
\hline C943 & Fumarolised Bi-tr & 0.704530 & 6 & 0.512730 & 4 & & \\
\hline
\end{tabular}

Table 5 Whole rock isotope data

Colour codes as in Table 4. In red: mean values of replicate (2 or 4) $\mathrm{Sr}$ and $\mathrm{O}$ analyses. $\mathrm{Nd}$ ratios in blue: samples for which $\mathrm{Fe}$ and $\mathrm{Ti}$ were removed (see Supplementary Data Information C). $\delta^{18} \mathrm{O}_{\mathrm{WR}} \%$ values are given on the reference scale VSMOW (see also Supplementary Data Information C). 


\section{References}

Agangi A., Kamenetsky V.S. and McPhie J., 2010. The role of fluorine in the concentration and transport of lithophile trace elements in felsic magmas: Insights from the Gawler Range Volcanics, South Australia. Chemical Geology, 273, 314-325.

Ambrosino F., Anastasio A., Bross A., Béné S., Boivin P., Bonechi L., Cârloganu C., Ciaranfi R., Cimmino L., Combaret Ch., D’Alessandro R., Durand S., Fehr F., Français V., Garufi F., Gailler L., Labazuy Ph., Laktineh I., Lénat J.-F., Masone V., Miallier D., Mirabito L., Morel L., Mori N., Niess V., Noli P., Pla-Dalmau A., Portal A., Rubinov P., Saracino G., Scarlini E., Strolin P. and Vulpescu B., 2015. Joint measurement of the atmospheric muon flux through the Puy de Dôme volcano with plastic scintillators and Resistive Plate Chambers detectors. Journal of Geophysical Research Solid Earth, 120, 1-18. doi:10.1002/2015JB011969.

Anderson A. T., 1968. The oxygen fugacity of alkaline basalt and related magmas, Tristan da Cunha. American Journal of Science, 266, 704-727.

Arnaud N., 1989. Les éruptions trachytiques de la Chaîne des Puys (Massif Central français). Apport de l'étude des enclaves congénères à l'évolution des magmas trachytiques. D.E.A. report, Université Blaise Pascal, Clermont II, Clermont-Ferrand, 33 pp.

Arnaud N.O., Gourgaud A. and Camus G., 1992. Sur la signification des enclaves des trachytes de la Chaîne des Puys (Massif Central français). Comptes Rendus de l'Académie des Sciences Paris, 314, série II, 2, 181-186.

Babuska V., Plomerova J., Vecsey L., Granet M. and Achauer U., 2002. Seismic anisotropy of the French Massif Central and predisposition of Cenozoic rifting and volcanism by Variscan suture hidden in the mantle lithosphere. Tectonics, 21, 4, 1029, 11-1-11-20.

Barclay J., Rutherford M.J., Carroll M.R., Murphy M.D., Devine J.D., Gardner J.E. and Sparks R.S.J., 1998. Experimental phase equilibria constraints on pre-eruptive storage conditions of the Soufriere Hills magma. Geophysical Research Letters, 25, 3437-3440.

Batard F., 1974. Les feldspaths dans les roches volcaniques différenciées du Massif Central français. Doctorat de $3^{\text {ème }}$ cycle Thesis, Université de Clermont-Ferrand, Clermont-Ferrand, $193 \mathrm{pp}$.

Bence A.E. and Taylor B.E., 1985. Rare Earth Element systematics of West Shasta metavolcanic rocks: Petrogenesis and hydrothermal alteration. Economic Geology, 80, 21642176. 
Bentor Y.K., 1951. On the formation of cloudy zones in plagioclases. Schweizerische mineralogische und petrographische Mitteilungen, 31, 535-552.

Bentor Y. K., 1954. La Chaîne des Puys (Massif Central français). Recherches géologiques et pétrographiques. Bulletin du Service de la Carte Géologique de France, LII(242), 373-806.

Blake S. and Campbell I.H., (1986). The dynamics of magma-mixing during flow in volcanic conduits. Contributions to Mineralogy and Petrology, 94, 72-81.

Boivin P. and Bachèlery P., 2009. Petrology of 1977 to 1998 eruptions of Piton de la Fournaise, La Réunion Island. Journal of Volcanology and Geothermal Research, 184, 1-2, 109-125. doi:10.1016/j.jvolgeores.2009.01.012.

Boivin P., Miallier D., Cluzel N., Devidal J.-L. and Dousteyssier B., 2015. Building and ornamental use of trachyte in the center of France during antiquity: Sources and criteria of identification. Journal of Archaeological Science: Reports, 3, 247-256.

Boivin P. and Thouret J.-C., 2013. Chaîne des Puys: a monogenetic field with domes, cones, maars and lava flows, pp. 53-82. In: André M.-F., Boivin P., Peiry J.-L., Thouret J.-C.. Volcanoes, Basins and Cultural Heritage of the Auvergne Region. International Conference on Geomorphology, Paris. Field trip P5 and International Symposium in Auvergne, 1-5 September 2013, 132 pp.

Boivin P. and Thouret J.-C., 2014. The volcanic Chaîne des Puys: a unique collection of simple and compound monogenetic edifices. In: Fort M. and André M.-F. (Editors), Landscapes and Landforms of France. Springer, Heidelberg, pp. 81-91.

Boivin P., Besson J.C., Briot D., Deniel C., Gourgaud A., Labazuy P., Langlois E., Larouzière F.-D. de, Livet M., Médard E., Merciecca C., Mergoil J., Miallier D., Morel J.-M., Thouret Jean C. and Vernet G., 2017. Volcanologie de la Chaîne des Puys. Carte au 1/25 000, format 120x90 cm, booklet 200 pp. Parc Naturel Régional des Volcans d'Auvergne, Montlosier.

Boudon G., Balcone-Boissard H., Villemant B. and Morgan D. J., 2015. What factors control superficial lava dome explosivity? Nature Scientific Reports, 5, 14551.

Buch L., von, 1802 [1841]. Observations faites sur les volcans d'Auvergne (traduction de 1841 par Madame de Kleinschrod avec notes de Henri Lecoq). Annales Scientifiques, XIV, 108184, 321-359.

Buddington A. F., Lindsley D. H., 1964. Iron-Titanium Oxide minerals and synthetic equivalents. Journal of Petrology, 5, 310-357. 
Burgisser A., Poussineau S., Arbaret L., Druitt T.H., Giachetti T. and Bourdier J.L., 2010. Pre-explosive conduit conditions of the 1997 Vulcanian explosions at Soufrière Hills Volcano, Montserrat: I. Pressure and vesicularity distributions. Journal of Volcanology and Geothermal Research, 194, 27-41.

Burgisser A., Arbaret L., Druitt T.H. and Giachetti T., 2011. Pre-explosive conduit conditions of the 1997 Vulcanian explosions at Soufrière Hills Volcano, Montserrat: II. Depth and overpressure distribution. Journal of Volcanology and Geothermal Research, 199, 193-205.

Calder E.S., Lavallée Y., Kendrick J.E. and Bernstein M., 2005. Lava dome eruptions. Chapter 18 in The Encyclopedia of Volcanoes, Elsevier, pp. 343-362. http://dx.doi.org/10.1016/B978-0-12-385938-9.00018-3.

Camus G., 1975. La Chaîne des Puys (Massif Central français). Étude structurale et volcanologique. Doctorat es Sciences Naturelles Thesis, Université de Clermont-Ferrand, Clermont-Ferrand, $327 \mathrm{pp}$.

Carloganu C. (on behalf of the Tomuvol Collaboration), 2018. Density imaging of Puy de Dôme volcano with atmospheric muons in French Massif Central as a case study for volcano muography. EGU Vienne 8-13 april 2018.

Cashman K. and Blundy J., 2000. Degassing and crystallisation of ascending andesite and dacite. Philosophical Transactions of the Royal Society A: Mathematical, Physical and Engineering Sciences, 358 (1770), 1487-1513.

Colombier M., Gurioli L., Druitt T., Shea T., Boivin P., Miallier D. and Cluzel N., 2017. Textural evolution of magma during the 9.4-ka trachytic explosive eruption at Kilian Volcano, Chaîne des Puys, France. Bulletin of Volcanology, 79, 17, 1-24.

Condomines M., 1997. Dating recent volcanic rocks through ${ }^{230} \mathrm{Th}^{2}{ }^{238} \mathrm{U}$ disequilibrium in accessory minerals: Example of the Puy de Dôme (French Massif Central). Geology, 25, 4, 375-378.

Cuoco E., Tedesco D., Poreda R.J., Williams J.C., De Francesco S., Balagizi C. and Darrah T.H., 2013. Impact of volcanic plume emisions on rain water chemistry during the January 2010 Nyamulagira eruptive event: Implications for essential potable water resources. Journal of Hazardous Materials, 244-245, 570-581.

Eichelberger J.C., Lysne P.C. and Younker L.W., 1984. Research drilling at Inyo domes, Long Valley Caldera, California. Eos, Transactions, American Geophysical Union, 65, 723-725. 
Faïn J., Miallier D., Montret M. and Sanzelle S., 1988. Zircon dating: regeneration and evaluation of the external dose. Nucl. Tracks Radiat. Meas, 14, 1-2, 333-337.

Fink J.H. and Griffiths R.W., 1998. Morphology, eruption rates, and rheology of lava domes: insights from laboratory models. Journal of Geophysical Research, 103, B1, 527-545.

Fouilland-Bergeat G., 2006. Étude volcanologique du Complexe Petit Puy de Dôme - Nid de la Poule. TER report, Université Blaise Pascal, Clermont-Ferrand, 27 pp.

Foury P., 1983. Étude pétrologique et expérimentale (à une atmosphère) d'une série alcaline continentale : la série de la Chaîne des Puys (Massif central français). Doctorat de $3^{\text {ème }}$ cycle Thesis, Université de Clermont-Ferrand, Clermont-Ferrand, 170 pp.

France L., Demacon M., Gurenko A.A. and Briot D., 2016. Oxygen isotopes reveal crustal contamination and a large, still partially molten magma chamber in Chaîne des Puys (French Massif Central). Lithos, 260, 328-338.

Glangeaud P., 1913. Les régions volcaniques du Puy de-Dôme II - La Chaîne des Puys et la Petite Chaîne des Puys. Bulletin du Service de la Carte Géologique de France, XXII(135), 241496.

Gourgaud A. and Camus G., 1984. Magma mixing at La Nugère (Chaîne des Puys, Massif Central, France). Role in trachyandesite genesis. Bulletin of Volcanology, 47, 4, 781-805.

Guettard J.-E., 1752. Mémoire sur quelques montagnes de la France qui ont été des volcans. Mémoires de 1'Académie Royale des Sciences, Paris, 27-59.

Haggerty S. B., 1976. Oxidation of opaque mineral oxides in basalts. In: Oxide minerals, Rumble R. (Editor), Mineral Society of America, pp. $\mathrm{Hg} 1-\mathrm{Hg} 100$.

Hale A.J. and Mühlhaus H.B., 2007. Modelling shear bands in a volcanic conduit: Implications for over-pressures and extrusion-rates. Earth and Planetary Science Letters, 263, 74-87.

Hale A.J. and Wadge G., 2008. The transition from endogenous to exogenous growth of lavadomes with the development of shear bands. Journal of Volcanology and Geothermal Research, 171, 237-257.

Hammer J.E., Cashman K.V. and Voight B., 2000. Magmatic processes revealed by textural and compositional trends in Merapi dome lavas. Journal of Volcanology and Geothermal Research, 100 (1-4), 165-192. 
Husain T., Elsworth D., Voight B., Mattioli G. \& Jansma P., 2014. Influence of extrusion rate and magma rheology on the growth of lava domes: insights from particle-dynamics modeling. Journal of Volcanology and Geothermal Research, 285, 100-117.

Husain T., Elsworth D., Voight B., Mattioli G. and Jansma P., 2018. Influence of conduit flow mechanics on magma rheology and the growth style of lava domes. Geophysical Journal international, 213, 1768-1784.

Innocenti S., Andreastuti S., Furman T., del Marmol M.A. and Voight B., 2013a. The preeruption conditions for explosive eruptions at Merapi volcano as revealed by crystal texture and mineralogy. Journal of Volcanology and Geothermal Research, 261, 69-86.

Innocenti S., del Marmol M.A., Voight B., Andreastuti S. and Furman T., 2013b. Textural and mineral chemistry contraints on evolution of Merapi Volcano, Indonesia. Journal of Volcanology and Geothermal Research, 261, 20-37.

Jeambrun M., Giot D., Bouiller R., Baudry D., Camus G., Guyonnaud G., Weecksteen G., 1973. Carte géologique détaillée de la France $1 / 50000^{\mathrm{e}}$. Feuille de Clermont-Ferrand ( $\mathrm{n}^{\circ} 693$ ). $1^{\text {ère }}$ édition, BRGM, Orléans.

Labazuy P., Boivin P., Dousteyssier B., Miallier D., Chanel C., Tréfond V., 2012. Analyse d'un levé LiDAR aéroporté haute résolution pour l'étude de la partie centrale de la Chaîne des Puys (Massif Central, France). $3^{\text {ème }}$ Colloque du CNFGG, Mesure et Modélisation en Volcanologie, 10-13 octobre 2012, Clermont-Ferrand, France.

Lacroix A., 1904. La Montagne Pelée et ses éruptions. Masson, Paris, 662 pp.

Lacroix A., 1908. Le mode de formation du Puy-de-Dôme et les roches qui le constituent. Comptes Rendus de l'Académie des Sciences Paris, 147, 826-831 and 1449.

Lafleur R., 2006. Étude volcanologique du Complexe Petit Puy de Dôme - Nid de la Poule. TER report, Université Blaise Pascal, Clermont-Ferrand, 31 pp.

Lanos P., Philippe A., Lanos H. and Dufresne P., 2015. Chronomodel: chronological modelling of Archaeological data using Bayesian statistics. (release 1.1 January 2015; release 1.5 March 2016). Available at: http://www.chronomodel.fr.

Lecoq H., 1867. Les époques géologiques de l'Auvergne. Baillière \& Fils, Paris, 5 volumes, $2714 \mathrm{pp}$.

Lepage L.D., 2003. ILMAT: an Excel worksheet for ilmenite-magnetite geothermometry and geobarometry. Computers and Geosciences, 29, 673-678 
Martel C., Champallier R., Prouteau G., Pichavant M., Arbaret L., Balcone-Boissard H., Boudon G., Boivin P., Bourdier J.L. and Scaillet B., 2013. Trachyte phase relations and implication for magma storage conditions in the Chaîne des Puys (French Massif Central). Journal of Petrology, 54, 6, 1071-1107.

Matthews S.J., Gardeweg M.C. and Sparks R.S.J., 1997. The 1984 to 1996 cyclic activity of Lascar Volcano, northern Chile: cycles of dome growth, dome subsidence, degassing and explosive eruptions. Bulletin of Volcanology, 59 (1), 72-82.

Maury R. C., Brousse R., Villemant B., Joron J. L., Jaffrezic H. and Treuil M., 1980a. Cristallisation fractionnée d'un magma basaltique alcalin : la série de la Chaîne des Puys (Massif Central, France) I, Pétrologie. Bulletin de Minéralogie, 103, 2, 250-266.

Maury R. C., D'Arco P. and Brousse R., 1980b. Températures et fugacités d'oxygène des magmas intermédiaires et différenciés du Mont Dore. Comptes Rendus Sommaires Société Géologique de France, 6, 242-245.

Melnik O. and Sparks R.S.J., 1999. Nonlinear dynamics of lava dome extrusion. Nature, 402, $37-41$.

Melnik O. and Sparks R.S.J., 2005. Controls on conduit magma flow dynamics during lava flow dome building eruptions. Journal of Geophysical Research, 110, B02209, 21pp.

Mergoil J. and Mergoil-Daniel J., 2014. Regards croisés sur le puy de Dôme au milieu du XVIII ${ }^{\mathrm{e}}$ siècle : Garmage, Guettard et les autres... Travaux du Comité français d'Histoire de la Géologie, XXVIII, $3^{\mathrm{e}}$ série (6), 107-150.

Merle O. and Michon L., 2001. The formation of the West European rift: a new model as exemplified by the Massif Central area. Bulletin de la Société Géologique de France, 172, 2, 213-221.

Miallier D., Boivin P., Deniel C., Gourgaud A., Lanos P., Sforna M. C. and Pilleyre T., 2010. The ultimate summit eruption of Puy de Dôme volcano (Chaîne des Puys, French Massif Central), about 10,700 y ago. Comptes Rendus de l'Académie des Sciences, Géoscience, 342, 847-854.

Miallier D., Pilleyre T., Sanzelle S., Boivin P. and Lanos P., 2012. Revised chronology of the youngest volcanoes of the Chaîne des Puys (French Massif Central). Quaternaire, 23, 4, 283290. 
Miallier D., Pilleyre T., Boivin P., Labazuy P., Gailler L. and Rico J., 2017. Grand Sarcoui volcano (Chaîne des Puys, Massif Central, France), a case study for monogenetic trachytic lava domes. Journal of Volcanology and Geothermal Research, 345, 125-141.

Michel-Lévy A., 1890. La Chaîne des Puys. Bulletin de la Société Géologique de France, $3^{\mathrm{e}}$ série, XVIII, 696-742.

Migdisov A., Guo X., Nisbet H., Xu H. and Williams-Jones A.E., 2019. Fractionation of REE, $\mathrm{U}$, and Th in natural ore-forming hydrothermal systems: Thermodynamic modeling. Journal of Chemical Thermodynamics, 128, 305-319.

Montlosier F.-D. de R. Comte de, 1788. Essai sur la théorie des volcans d'Auvergne, 184 pp.

Nelson S.T. and Montana A., 1992. Sieve-textured plagioclase in volcanic-rocks produced by rapid decompression. American Mineralogist, 77, 11-12, 1242-1249.

Nemeth K. and Kereszturi G. (2015). Monogenetic volcanism: personal views and discussion. International Journal of Earth Sciences, 104, 8, 2131-2146. doi:10.1007/s00531-015-1243-6

Neuberg J.W., Tuffen H., Collier L., Green D., Powell T. and Dingwell D., 2006. The trigger mechanism of low-frequency earthquakes on Montserrat. Journal of Volcanology and Geothermal Research, 153, 37-50.

Nisbet H., Migdisov A., Xu H., Guo X., van Hinsberg V., Williams-Jones A.E., Boukhalfa H. and Roback R., 2018. An experimental study of the solubility and speciation of thorium in chloride-bearing aqueous solutions at temperatures up to $250^{\circ} \mathrm{C}$. Geochimica et Cosmochimica Acta, 239, 363-373.

Papike J.J., Keith T.E.C., Spilde M.N., Galbreath K.C., Shearer C.K. and Laul J.C., 1991. Geochemistry and mineralogy of fumarolic deposits, Valley of Ten Thousands Smokes, Alaska: Bulk chemical and mineralogical evolution of dacite-rich protolith. American Mineralogist, 76, 1662-1673.

Poldervaart A. and Gilkey A.K., 1954. On clouded plagioclase. American Mineralogist, 39, 75-91.

Portal A., Gailler L.S., Labazuy P. and Lénat J.F., 2016. Geophysical imaging of the inner structure of a lava dome and its environment through gravimetry and magnetism. Journal of Volcanology and Geothermal Research, 320, 88-99. 
Portal A., Fargier Y., Labazuy P., Lénat J.-F., Boivin P. and Miallier D., 2019. 3D electrical imaging of the inner structure of a complex lava dome, Puy de Dôme volcano (French Massif Central, France). Journal of Volcanology and Geothermal Research, 373, 97-107.

Poulett-Scrope G., 1827. Memoir on the geology of Central France, including the volcanic formations of Auvergne, the Velay and the Vivarais. Murray, London, $182 \mathrm{pp}$.

Ramond L., 1815. Nivellement barométrique des Monts Dore et des Monts Dômes disposé par ordre de terrains. Mémoires de l'Académie des Sciences Institut de France, 1-176.

Sforna M. C., 2008. Mise en relation des phases éruptives du Puy de Dôme et de la nature pétrologique et géochimique des laves. Master Research report, Université Blaise Pascal, Clermont-Ferrand, $53 \mathrm{pp}$.

Sherrod D.R., Scott W.E. and Stauffer P.H. (Eds.), 2008. A volcano rekindled: the renewed eruption of Mount St. Helens, 2004-2006. U.S. Geological Survey. Professional Paper 1750.

Sourisseau J., 2007. Les trachytes du Puy de Dôme. TER report, Université Blaise Pascal, Clermont-Ferrand, $23 \mathrm{pp}$.

Sparks R.S.J., 1997. Causes and consequences of pressurisation in lava dome eruptions. Earth and Planetary Science Letters, 150, 177-189.

Sparks R.S.J., Murphy M.D., Lejeune A.M., Watts R.B., Barclay J. and Young S.R., 2000. Control on the emplacement of the andesite lava dome of the Soufriere Hills volcano, Montserrat by degassing-induced crystallisation. Terra Nova, 12(1), 14-20.

Stix J., Torres R.C., Narvaez M.L., Cortés G.P., Raigosa J.A., Gomez D.M. and Castonguay R., 1997. A model of Vulcanian eruptions at Galeras Volcano, Colombia. Journal of Volcanolology and Geothermal Research 77, 285-304.

Sun S.S. and McDonough W.F., 1989. Chemical and isotopic systematics of oceanic basalts: implications for mantle composition and processes. In: Saunders AD, Norry MJ (eds) Magmatism in the ocean basins. Geological Society of London Special Publication, 42, 313345 .

Van Wyk de Vries B., Marquez A., Herrera R., Granja Bruna J.L., Llanes P. and Delcamp A., 2014. Craters of elevation revisited: forced-folds, bulging and uplift of volcanoes. Bulletin of Volcanology, 76: 875. 
Vialette Yves, 1962. Contribution à l'étude géochronologique par la méthode au strontium des principaux massifs de granites et de migmatites du massif central français. Doctorat es Sciences Naturelles Thesis, Université de Clermont-Ferrand, Clermont-Ferrand, 88 pp.

Villemant B., Joron J.L., Jaffrezi, H., Treuil M., Maury R.C. and Brousse R., 1980. Cristallisation fractionnée d'un magma basaltique alcalin : la série de la Chaîne des Puys (Massif Central, France) II, Géochimie. Bulletin de Minéralogie, 103, 2, 267-286.

Watts R.B., Herd R.A., Sparks R.S.J. and Young S.R., 2002. Growth patterns and emplacement of the andesitic lava dome at Soufrière Hills Volcano, Montserrat. In: Druitt T.H., Kokelaar B.P. (Editors), The Eruption of Soufrière Hills Volcano, Montserrat from 1995 to 1999. Geological Society of London, Memoir, 21, pp. 115-152.

Wood S.A., van Middlesworth P., Gibson P. and Ricketts A., 1997. The mobility of the REE, $\mathrm{U}$ and Th in geological environments in Idaho and their relevance to radioactive waste disposal. Journal of Alloys and Compounds, 249, 136-141.

Zhao Z-F and Zheng Y-F, 2003. Calculation of oxygen isotope fractionation in magmatic rocks. Chemical Geology, 193, 59-80.

Zeyen H., Novak O., Landes M., Prodehl C., Driad L. and Hirn A., 1997. Refraction-seismic investigations of the northern Massif Central (France). In: K. Fuchs, R. Altherr, B. Mueller and C. Prodehl (Editors), Tectonophysics. Elsevier, Amsterdam, pp. 99-117. 